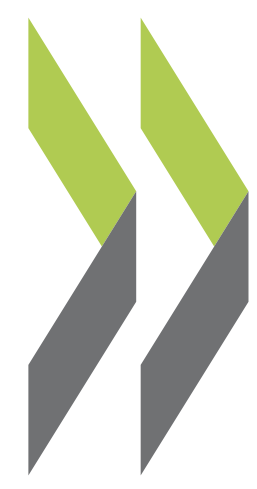

OECD Economics Department Working Papers No. 949

Romain Bouis,

The Short-Term Effects Orsetta Causa, of Structural Reforms: An Lilas Demmou, Empirical Analysis Romain Duval, Aleksandra Zdzienicka 


\section{Unclassified}

ECO/WKP(2012)26

Organisation de Coopération et de Développement Économiques

Organisation for Economic Co-operation and Development

26-Mar-2012

ECONOMICS DEPARTMENT

English text only

THE SHORT-TERM EFFECTS OF STRUCTURAL REFORMS: AN EMPIRICAL ANALYSIS

ECONOMICS DEPARTMENT WORKING PAPER No.949

by

Romain Bouis, Orsetta Causa, Lilas Demmou, Romain Duval and Aleksandra Zdzienicka

All Economics Department Working Papers are available through OECD's internet website at www.oecd.org/eco/workingpapers

JT03318630

Complete document available on OLIS in its original format

This document and any map included herein are without prejudice to the status of or sovereignty over any territory, to the delimitation of international frontiers and boundaries and to the name of any territory, city or area. 


\section{ABSTRACT/RÉSUMÉ}

\section{The Short-Term Effects of Structural Reforms: an Empirical Analysis}

Drawing on new empirical analysis of 30 years of structural reforms across the OECD, this paper sheds light on the impact of reforms over time, identifies the horizon over which their full effects materialise, and investigates whether such effects vary with prevailing economic conditions and institutions. Impulse responses of aggregate outcomes (GDP growth, employment rate) to various labour, product market and tax reforms are estimated at different horizons. This analysis indicates that the benefits from reforms typically take time to fully materialise. When significant effects are found in the short run, reforms seldom involve significant aggregate economic losses; on the contrary they often deliver some benefits. The absence of major depressing effects does not lend support to the view that reforms should be in general accompanied by substantial macroeconomic policy easing in order to deliver some short-term gains. Nevertheless, there is also tentative evidence that some labour market reforms (e.g. of unemployment benefit systems and job protection) pay off more quickly in good times than in bad times, and can even entail short-term losses in severely depressed economies.

JEL classification: E02; E21; E22; E24; E60; J21; J23; J38; J58; J68.

Key words: Institutions; reforms; labour market; product market; tax system; macroeconomic conditions; impulse response function.

\section{L’impact à court terme des réformes structurelles : une analyse empirique}

Cet article s'appuie sur des données portant sur trente années de reformes structurelles dans les pays de l'OCDE et analyse l'impact de ces reformes au cours du temps. Nous cherchons plus particulièrement à identifier l'horizon temporel à partir duquel ces effets se matérialisent ainsi qu'à déterminer la façon dont le positionnement dans le cycle économique ou les arrangements institutionnels en vigueur dans chaque pays affectent les résultats. L'analyse empirique repose sur l'estimation, à différents horizons temporels, de taux de réponse des variables de performances (taux de croissance du PIB, taux d'emploi) à des reformes mises en œuvre dans le domaine fiscal, sur le marché du travail ainsi que sur le marché des produits. D’après nos résultats, les effets des reformes mettent généralement du temps à se matérialiser. Lorsque des effets significatifs sont obtenus dès le court terme, l'analyse indique que les réformes ne génèrent que très rarement des coûts macroéconomiques alors qu'un certain nombre d'entre elles produisent rapidement des bénéfices. L'absence d'effet récessif majeur semble donc infirmer l’idée selon laquelle les reformes devraient généralement être accompagnées de politiques macroéconomiques accommodantes permettant de compenser les coûts qui y seraient associés. Cependant, les résultats indiquent également que les effets bénéfiques des réformes du marché du travail (tels que celles du système d'assurance chômage ou de la protection du travail) se matérialisent surtout dans des situations de croissance économique alors qu'une détérioration des performances à court terme peut survenir lorsqu'elles sont appliquées en période de ralentissement économique.

JEL Classification JEL : E02 ; E21 ; E22 ; E24 ; E60 ; J21 ; J23 ; J38 ; J58 ; J68.

Mots clés : Key words: Institutions; réformes; marché du travail; marché des produits; système fiscal; conditions macroéconomiques; fonction de réponse impulsionnelle.

(c) OECD (2012)

You can copy, download or print OECD content for your own use, and you can include excerpts from OECD publications, databases and multimedia products in your own documents, presentations, blogs, websites and teaching materials, provided that suitable acknowledgment of OECD as source and copyright owner is given. All requests for commercial use and translation rights should be submitted to rights@oecd.org. 


\section{TABLE OF CONTENTS}

THE SHORT-TERM EFFECTS OF STRUCTURAL REFORMS: AN EMPIRICAL ANALYSIS ..............5

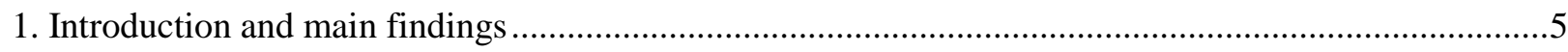

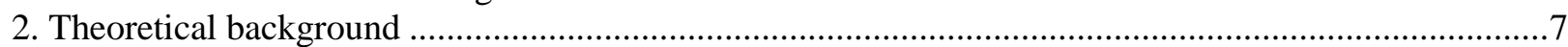

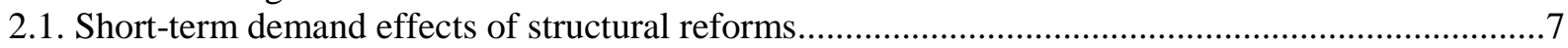

2.2. Short-term supply effects of structural reforms...........................................................................

2.3. Political economy considerations shaping the short-term effect of reforms ...................................10

2.4. The role of structural settings and macroeconomic policies ...........................................................11

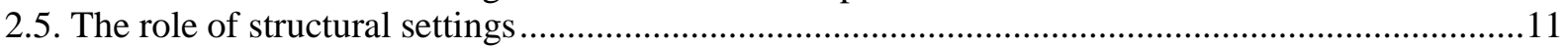

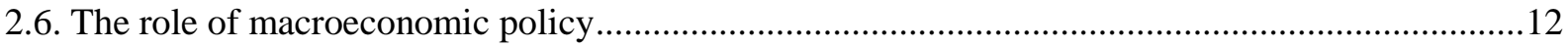

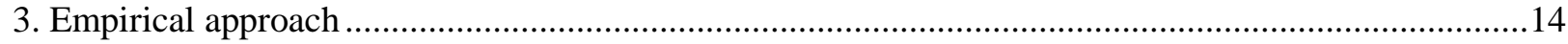

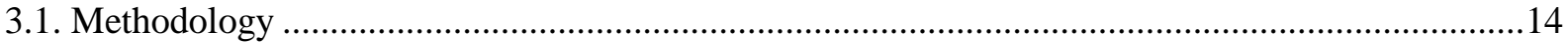

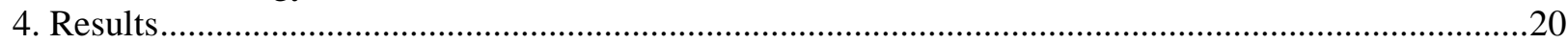

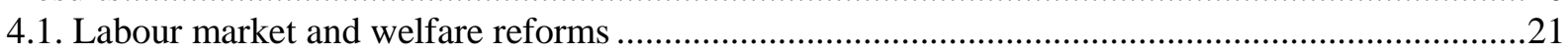

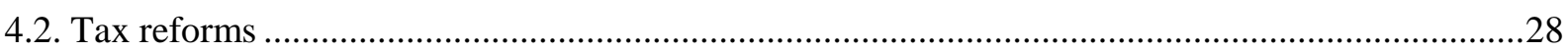

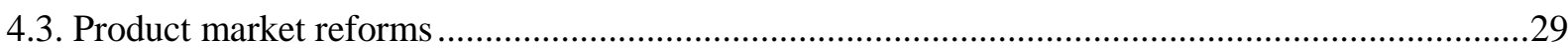

4.4. Interactions between structural reforms and macroeconomic conditions and policies .....................30

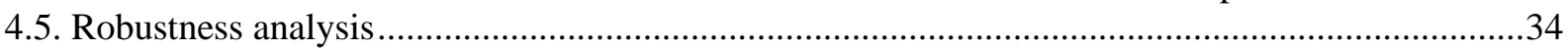

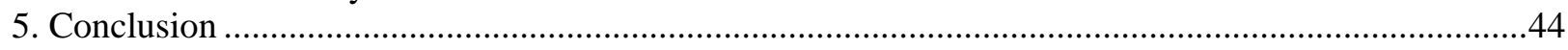

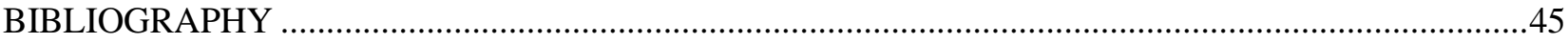

ANNEX - SOURCES, DEFINITION, AND COVERAGE OF VARIABLES ...........................................50

\section{Tables}

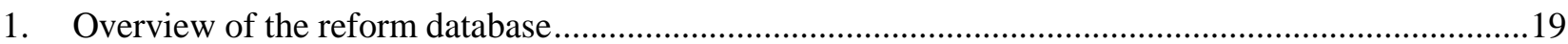

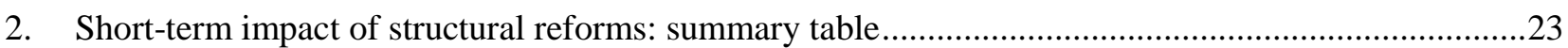

3. Short-term employment effects of structural reforms: the influence of economic conditions ...............32

4. Short-term employment effects of structural reforms: the influence of job protection .........................33

5. Short-term impact of reforms: robustness to the use of a more stringent criterion for the identification

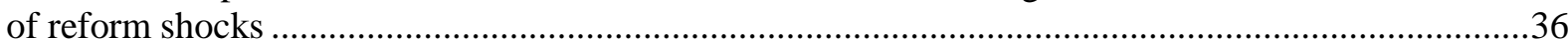

6. Short-term impact of reforms: Robustness to the use of a less stringent criterion for the identification

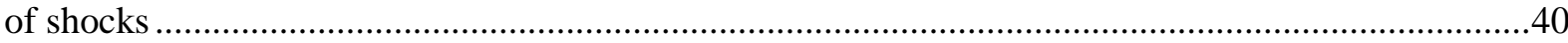

7. Short-term impact of structural reforms: robustness to controlling for "reverse"

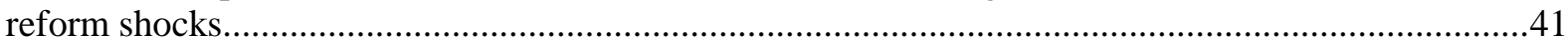

8. Short-term impact of structural reforms: robustness to the exclusion of country fixed effects ..............42

9. Short-term impact of structural reforms: robustness to using an alternative dynamic model ................45

10. Short-term impact of structural reforms: assessing the overall robustness of the results ......................46

\section{Figures}

1. Change in aggregate employment following a reduction in the initial unemployment benefit

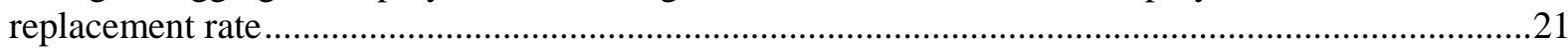

2. Change in youth unemployment following a reduction in unemployment benefit duration .................22

3. Change in female unemployment following a reduction in job protection on regular contracts...........24

4. Change in aggregate employment following a reduction in job protection on temporary contracts 
5. Change in aggregate employment following an increase in spending on ALMP employment incentives

6. Change in female employment following an increase in spending on ALMP in training ....................27

7. Change in female unemployment following a decline in excess bargaining coverage..........................28

8. Change in female labour force following a reduction in share of income taxes in total tax revenues.

9. Change in aggregate labour force following a decline in product market regulation

10. Change in aggregate employment following a reduction in initial unemployment benefit replacement rate: the influence of economic conditions

The statistical data for Israel are supplied by and under the responsibility of the relevant Israeli authorities. The use of such data by the OECD is without prejudice to the status of the Golan Heights, East Jerusalem and Israeli settlements in the West Bank under the terms of international law. 
ECO/WKP(2012)26

THE SHORT-TERM EFFECTS OF STRUCTURAL REFORMS: AN EMPIRICAL ANALYSIS

\author{
by
}

\author{
Romain Bouis, Orsetta Causa, Lilas Demmou, Romain Duval and Aleksandra Zdzienicka ${ }^{1}$
}

\title{
1. Introduction and main findings
}

1. There is a large strand of theoretical and empirical research devoted to the analysis of the longterm impact of structural reforms, but much less is known about their short-term effects. The goal of this paper is to shed light on the impact of structural reforms over time, identify the horizon over which the full effects of reforms materialise, and investigate how such effects vary with economic conditions, as well as macroeconomic and institutional settings. Knowledge of their dynamic effects may be a factor influencing the structural reform agenda, especially in the current context where macroeconomic policies are constrained in a number of OECD countries. As is always the case, but presumably differently so in a postcrisis context, political economy considerations (such as political feasibility) or tradeoffs between different objectives (such as efficiency versus equity considerations) may also shape the design of structural reforms and as a consequence their short-term effects.

2. The short- and long-term impacts of structural reforms may differ. Long-term gains can come with transition costs, due for example to the disappearance of incumbent firms during liberalisation episodes and the associated sunk costs (scrapping of physical capital and loss of firm-specific human capital) or to the existence of time lags associated with adjustments costs to the new equilibrium. ${ }^{2}$ Indeed, the existence of short-run costs associated with structural reforms is, along with their uneven distribution across individuals and firms, one of the motivations behind political resistance to the reform process. Structural reforms might even be contractionary in the short term, for instance if they increase perceived income insecurity and precautionary savings. Insofar as some reforms create economic slack, and influence macroeconomic conditions more broadly, the response of monetary and fiscal policies will also shape their short-term impact. Yet, the empirical literature has been silent on these dynamics.

3. Some structural reforms could boost growth already in the short run. This might be a particularly attractive property at the current juncture where room is limited for macroeconomic policy to compensate or offset any short-term drag from reform. For instance, short-run expansionary effects from structural reforms may sometimes be driven by improved confidence and expectations of future income gains. And forward-looking financial markets should price longer-term economic prospects - and therefore the effects of reforms - into asset prices, thus boosting near-term activity, though this effect may be less strong at a time of impaired financial markets. Structural reforms may also have different short-run effects depending on pre-existing institutional settings and macroeconomic policies. Identifying interdependencies among policies and institutions should help assess how to minimise any transition costs from reforms.

4. Answering such questions would ideally call for an analysis of the short-term effects of reforms on both actual outcomes (e.g. output and employment) and measures of economic slack (e.g. output and employment gaps). In practice, partly reflecting methodological issues and because of the difficulty to

1. At the time of writing, Romain Bouis, Orsetta Causa, Lilas Demmou and Romain Duval were members of the OECD Economics Department, while Aleksandra Zdzienicka was a member of the CEPII and participated in this study as part of collaboration between the OECD and the CEPII.

2. See e.g. Blanchard and Giavazzi (2003); Everaert and Schule (2008); Cacciatore and Fiori, (2010); Cacciatore et al. (2012). 
identify the short-term effect of any reform on potential output, the focus of the empirical analysis - and of much of this paper more broadly - is on the observed as opposed to the unobservable effects of structural reforms. This makes it impossible to assess the extent to which the estimated impact of reforms (e.g. on output) reflects their effect on equilibrium variables (e.g. potential output) or the difference between actual and equilibrium variables (e.g. the output gap). Concretely, impulse responses of various macroeconomic and labour market outcomes (GDP growth, employment rate...etc) to various reform "shocks" in the areas of labour, product markets and taxation are identified for a panel of OECD countries spanning over three decades. This approach allows some analysis of the dynamic effects of multiple reforms on a wide range of observed outcomes.

5. The paper is structured in the following way. Section 1 provides the theoretical background. It first discusses the expected short-term impact of different reforms by identifying the different channels of transmission and associated key driving factors. It then addresses the role of the overall policy and institutional context and macroeconomic policies in shaping the dynamic impact of structural reforms. Section 2 describes the empirical approach. Section 3 provides empirical evidence of the dynamic impact of major reforms along with robustness checks. Section 4 concludes.

6. Bearing in mind that evidence on this little researched field is necessarily incomplete and sketchy, the main findings are:

- New empirical evidence suggests that the benefits from reforms often take time to materialise. This is consistent with frictions in labour and product markets. However, and somewhat surprisingly, at most weak evidence is found that certain reforms may entail short-term losses in aggregate output or employment.

- Unemployment benefit reforms appear to boost employment relatively quickly, possibly because they boost job search and hires without much affecting lay-offs. Consistent with their employment effects, such reforms are also found to be associated with stronger investment and output growth. However, the empirical analysis suggests that reducing the generosity of unemployment income support could have negative short-run effects in "bad times", i.e. when output and employment are substantially below potential. Therefore, cutting the level or duration of unemployment benefits could run the risk of making the labour market situation temporarily worse in depressed economies.

- The short-term effects of strengthening activation policies are hard to identify. There is nevertheless tentative empirical evidence that increased expenditures on training and employment incentives are associated with lower unemployment in the short run. Hence, to support the jobs recovery, there is a case for sheltering resources devoted to active labour market policies from fiscal consolidation efforts.

- There is tentative empirical evidence that tackling labour market duality by reducing the difference in contract provisions between permanent and temporary workers may reduce unemployment in the short run, in particular for youth and women. However, as for unemployment benefit reforms, this finding no longer holds and is even reversed in the presence of labour market slack - though conclusions may shift again if job protection reform applies only to new contracts, an option not explored in this paper.

- By contrast, two-tier reforms of job protection, i.e. a loosening of restrictions on the use of temporary contracts while keeping strong protection of permanent contracts unchanged, is tentatively found to reduce employment in the short to medium term. This broadly confirms previous analysis, including by the OECD, which highlighted the weaknesses of two-tier reforms 
of job protection, i.e. reforms aimed at reducing job protection on temporary contracts while maintaining stringent provisions for regular workers.

- Growth-friendly revenue-neutral tax reforms that shift the tax burden away from direct taxes are found to reduce unemployment relatively quickly, particularly so for youth. After a few years, such reforms also appear to trigger stronger female and youth participation. This indicates that improving the tax structure can have positive labour supply and labour demand effects. Moreover, empirical results suggest that such reforms also boost private investment.

- Product market reforms in transport, energy and communication industries are found to increase labour force participation along with private consumption growth. However, somewhat surprisingly and at odds with recent OECD empirical analysis (Kerdrain et al., 2010), private investment and GDP seem to be temporarily depressed, possibly reflecting capital spending cuts by incumbent firms.

- Product market reforms are found to reduce employment and increase unemployment under weak job protection. This finding points to substitutability between product and labour market reforms, i.e. a combination of reforms would yield smaller long-term gains than the sum of the effects of each of them taken in isolation - a finding which is in line with theoretical results from the companion OECD paper (Cacciatore et al., 2012) but not with previous empirical evidence of long-run complementarity across reforms (Bassanini and Duval, 2009).

- While in principle monetary and fiscal accommodation may help crowd in the effects of reforms, the results in this paper do not lend support for such macroeconomic policy easing in practice. Indeed, empirical evidence suggests that the short-term effects of structural reforms - at least of past reform episodes identified in this paper - on output and employment are positive or null in general, and in any event too small to warrant a major macroeconomic policy response. This conclusion should be qualified, however, since an estimated positive or null impact of reforms could still be associated with a negative output gap - and therefore a case for macroeconomic policy intervention - insofar as actual output or employment levels rise less than potential.

\section{Theoretical background}

7. Structural reforms are typically aimed at increasing steady-state labour productivity or labour utilisation, or both. However, their effects may not materialise immediately, depending in part on their effects on aggregate demand and supply. This section reviews the main channels through which reforms may shift demand and supply, and also briefly discusses the influence of political economy factors on the design - and therefore the short-term impact - of reforms (for detailed OECD analysis of some of these channels in a theoretically-consistent dynamic general equilibrium framework, see Cacciatore et al., 2012). ${ }^{3}$

\subsection{Short-term demand effects of structural reforms}

8. Structural reforms may affect aggregate demand through several channels. One such channel is the "multiplier effect" of their fiscal implications. The size of this impact will depend on the presence and the nature of offsetting budgetary measures. If (fiscally) costly reforms are financed by debt, their short-run effects on aggregate demand via this channel are likely to be higher when they are associated with

3. Previous OECD work also examined the nature and length of economic adjustments to selected labour market reforms, drawing on descriptive analysis and simulations using Dynamic General Equilibrium models (Mourougane and Vogel, 2008). 
spending increases or revenue reductions that feature the strongest fiscal multipliers, such as increases in government productive expenditure e.g. on education and infrastructure. ${ }^{4}$ If costly reforms are financed through other budgetary measures, the short-run effects are likely to be maximised when the offsetting budgetary items feature the lowest multipliers. Likewise, revenue-raising reforms would have a differential short-term impact depending on the existence and nature of revenue recycling. For example, the potential negative effect of a cut in unemployment benefits on disposable income and liquidity constrained consumption would be stronger when no offsetting scheme is introduced to balance the budget. When possible, introducing offsetting fiscal measures aimed at stabilising consumption of liquidity-constrained households during the transition period would help reducing any short-term contractionary effect associated with such a reform. ${ }^{5}$

9. Multiplier effects aside, the positive or negative impacts of reforms on demand also depend on how they affect confidence, income and wealth:

- $\quad$ Positive confidence, income and wealth effects may result from reform-driven changes in future incomes. The positive effects of structural reforms on future income may be incorporated into perceptions of permanent income. They may also be reflected into forward-looking asset prices. ${ }^{6}$ In turn, the associated increase in household wealth may boost consumption and investment directly, or indirectly by easing households' credit constraints via improved collateral. In this regard, a well-functioning financial sector is instrumental for bringing forward the gains from reforms, since it allows households and firms to borrow against future income or collateral. ${ }^{7}$

- Lifecycle income effects should most often be positive but reform design also plays a role. For instance, a pension reform that cuts future replacement rates may reduce aggregate consumption in the short run insofar as some households seek to save more to make up for reduced retirement income in the future. By contrast, a pension reform that increases the minimum or standard retirement age may temporarily stimulate consumption as households expect to work over a longer time horizon and hence can reduce saving while maintaining their future living standards (Kerdrain et al., 2010).

- Negative confidence effects may arise from households' perception of higher income insecurity in the wake of certain reforms, leading to higher precautionary savings and lower demand. For instance, reducing job protection might adversely affect households' consumption by increasing

4. The magnitude of fiscal multipliers also obviously depends on a host of more general factors, such as e.g. external trade openness, whether consumers are more or less Ricardian, etc. See e.g. Botman et al. (2007) for a discussion on the dynamic effects of fiscal reforms based on the IMF Global Fiscal Model, and see Sutherland et al. (2010) for in-depth review of fiscal multipliers. Recent empirical work, which largely confirms previous evidence (including OECD evidence, see Arnold, 2008; Sutherland et al., 2010) has provided a classification of taxes and expenditure categories according to their short and long-run growth effects (Gemmell et al. 2011). Increases in government productive expenditure such as education and infrastructure and cuts in distortionary taxes such as taxes on labour and capital have the largest short-term fiscal multipliers.

5. This is consistent with Mourougane and Vogel (2008) who show, in the context of a DGE model with liquidity-constrained households, that the short-run impact of reforms that lower the NAIRU on disposable income and consumption depends on the way reforms are financed (self-financing reforms or introduction of a recycling mechanism to balance the budget).

6. In the absence of credit constraints and under perfect information about the future income gains from reforms, there is no distinction between permanent income and wealth effects.

7. $\quad$ Angeloni et al. (2003); Mishkin (2007). 
labour turnover and job insecurity, even if such reform does not trigger higher overall unemployment and increases exit rates from unemployment.

10. Reforms may boost short-term supply, demand and output when they lift supply constraints where there is pent-up demand. This is typically relevant for product market regulations that prevent for instance the entry of new firms in telecommunications - as past experience with liberalisation of this sector suggests - but also in retail trade and professional services. Cross country-evidence on the negative impact of economy-wide entry regulation on employment growth is abundant (see e.g. Alesina et al., 2005). In turn, reducing economy-wide barriers to firm entry might bring relatively quick employment gains, especially when reforms make it easier to create a firm and recruit workers (see Bertrand and Kramarz, 2002, for evidence on retail trade in France). ${ }^{8}$

11. The short-term demand effects of structural reforms may be different when the economy is near the zero lower bound (ZLB) of nominal interest rates (Fernandez et al., 2011). In such a situation, structural reforms boosting future labour productivity are likely to trigger short-term increases in demand as a result of positive wealth effects which, since the economy is at the ZLB, will not be dampened by interest rates hikes. On the contrary, structural reforms boosting current labour productivity are likely to trigger short-term reductions in demand insofar as such reforms would potentially aggravate the deflationist effects of the interest rates at ZLB. Product market or job protection reforms could fall in the former category, while labour-supply enhancing reforms - such as unemployment benefit and pension reforms - could fall in the latter.

\subsection{Short-term supply effects of structural reforms}

12. The supply-side gains from reforms are typically thought as of long-run effects. The time it takes to reach the long-run equilibrium may differ across policy areas depending on a number of factors:

- Measures to stimulate knowledge and innovative activities, such as education reforms and innovation policies require a long time to deliver their full benefits. ${ }^{9}$ In a similar vein, the effects of lighter product market regulation on productivity through technology adoption by incumbent firms might take time to materialise.

- Slow adjustment to long-run equilibrium might also characterise reforms that raise productivity through reallocation of production factors. To the extent that the productivity impact of job protection (Bassanini et al., 2009) or certain housing market reforms - e.g. those that promote workers' mobility - are channelled through labour reallocation across firms and industries, such reforms might be associated with relatively long transitional dynamics. Financial market liberalisation may also take a long time to achieve a more efficient capital allocation and to boost productivity, although it may also have large short-term effects through other channels (e.g. by lifting credit constraints).

- On the contrary, reforms that reduce $X$-inefficiencies at the firm and industry level may have an immediate positive impact on labour productivity. Efficiency-enhancing public sector reforms aimed at reducing slack in certain publicly-run sectors or state-owned enterprises may fall in this

8. Similar conclusions can be drawn from empirical evidence provided in Branstetter et al. (2010) who study the impact of economy-wide entry deregulation in Portugal and show that retail trade is among the industries that experience the strongest employment gains as a result of the reform.

9. These reforms may still have demand effects if unfinanced, as discussed above. 
category. ${ }^{10}$ Similarly, the productivity gains associated with trade liberalisation and product market reform are likely to materialise more quickly in industries characterised by $\mathrm{X}$ inefficiencies. ${ }^{11}$ At the same time, such productivity gains can be concomitant with employment losses. While labour shedding is immediate, it may take time before the displaced workers find a new job. The latter argument also applies to job protection reforms, which might trigger a shortrun increase in unemployment inflows as it becomes immediately profitable for firms to fire marginally unproductive workers (see e.g. Cacciatore et al., 2012).

- $\quad$ Some reforms may entail short-term supply losses, e.g. due to capital scrapping. This can be the case of abrupt industry-level liberalisation that triggers the disappearance of incumbent firms, whereby not only physical but also potentially firm-specific human capital can be destroyed. Such effects might also arise as a result of an abrupt removal of public subsidies, absent any compensatory scheme.

- The labour supply effects of structural reforms may take more time to materialise when they entail cohort effects. Pension reforms are often associated with substantial grandfathering in the form of long transition periods. To the extent that such reforms do not affect current generations of older workers but future ones, their expected impact on older workers' labour supply might come with a long lag. Expectations of forthcoming reforms may even speed up labour market withdrawal in the short term.

\subsection{Political economy considerations shaping the short-term effect of reforms}

13. The short-run impact of reforms may also depend on their design, and in particular on whether (Boeri, 2010): i) reforms are two-tier or complete in nature, i.e. whether they are confined to a subset of or cover the whole eligible population; ii) reforms are incremental or discrete, i.e. whether they involve a small institutional change or a large one. There are specific transitional dynamics associated with two-tier reforms. For instance, recent literature has analysed the labour demand impact of easing the use of temporary employment contracts while the legislation on permanent contracts is unchanged (Boeri and Garibaldi, 2007; Boeri, 2010). Reforms of this type involve a temporary "honeymoon effect" on employment as firms exploit the higher hiring flexibility. These employment gains are transitory though, because over time they are compensated by the natural job outflow of insider workers - workers under permanent contracts.

14. Reform design also includes governments' communication strategy. Positive demand effects are more likely insomuch as forward-looking economic agents are given clear and timely information about reform implementation. Similarly, informing economic agents about forthcoming reforms can help frontload their impact. This is typically the case of pension reforms, which can be incorporated in agents' life-cycle consumption path. Announcing reforms in advance may thus be a useful way to reduce shortterm adjustment costs. For instance, announcing a product market reform before it is actually implemented can trigger immediate (but gradual) adjustment by firms, accelerating the upside adjustment in potential supply (Adjémian et al., 2007). A related argument can be made about the impact of government commitment on the short-term effects of reforms. Reforms introduced with broad political support will solicit greater and faster response as they are less likely to be rolled back.

10. It has to be recognised though that such effect can be difficult to identify in the data due to the issue of productivity measurement in public services.

11. For example, recent firm-level empirical work shows that Australia's manufacturing productivity gains in the mid-1990s were mostly accounted for by the reduction in X-inefficiencies through employment shedding in industries experiencing a high degree of trade liberalisation (Palangkaraya and Yong, 2011). 
15. Structural reforms can come with short-term redistributive effects, which is usually the main source of political opposition to the reform process. Designing reforms to address these concerns may strengthen or weaken their short-run effects. For instance, the potential negative short-run aggregate demand impact of reduced duration of unemployment benefits might be dampened if well-designed meanstested transfers are concomitantly introduced. ${ }^{12}$ On the contrary, when political opposition implies compensating losers by implementing incomplete or phased-in reforms, the positive (supply) impact of the reform process will take more time to materialise.

\subsection{The role of structural settings and macroeconomic policies}

16. Structural policy settings are likely to shape the transitional dynamics associated with the reform process. Macroeconomic policies in turn affect the speed at which reforms can deliver their full benefits given the institutional settings. This section discusses the potential mechanisms at play, starting with structural policy settings before turning to macroeconomic policies.

\subsection{The role of structural settings}

17. There is a massive theoretical and empirical literature on the impact of structural policy interactions on long-term outcomes, ${ }^{13}$ but much less is known on the short-run interdependencies. Broadly speaking, the time it takes for the economy to reach its new long-term equilibrium in the aftermath of a reform which boosts potential output or employment is likely to be shaped by nominal and real rigidities, which in turn depend on institutional settings: ${ }^{14}$

- $\quad$ Higher nominal rigidities - stronger price or wage stickiness - are likely to delay the full impact of a reform, ceteris paribus. Price stickiness may delay the adjustment process in the aftermath of productivity-enhancing reforms. For instance, the removal of entry barriers in product markets would yield slower real income gains because it would take longer for producers to react to entry threat by reducing mark-ups. Price and nominal rigidities can result from various institutional settings underpinning imperfect product and labour market competition, such as product market regulations and stringent job protection (Holden, 1994, 2004; Messina et al., 2010).

- $\quad$ Real rigidities (including non-wage rigidities) can also shape the dynamic impact of reforms. For instance, institutional settings that favour labour reallocation such as well-designed active labour market policies (ALMPs) or housing policies might speed the adjustment to long-run equilibrium. Hence, the removal of entry or trade barriers in product markets might boost employment and productivity faster if existing ALMPs improve workers' reallocation and the job matching process. Conversely, the positive impact of job protection reform on productivity (Bassanini et al., 2009) might materialise more slowly in the presence of housing policies that hinder labour mobility (Andrews et al., 2011). To the extent that job protection itself increases

12. Increasing spending on training can also enhance the short-run labour supply effect of the reform by speeding up return to work.

13. Theoretical models include Blanchard and Giavazzi (2003); Fiori et al. (2008). Empirical analyses include Nicoletti and Scarpetta (2003, 2005); Griffith et al. (2007); Amable et al. (2011); and Bassanini and Duval (2009).

14. This section focuses on the role of institutional settings associated with nominal and real rigidities in shaping the dynamic impact of structural reforms, but for simplicity it omits the possible endogenous (postreform) reduction in the nominal or real rigidity driven by the reform considered itself. Moreover, this section does not address the potential interactions between nominal and real wage rigidities themselves (see Duval and Vogel, 2007). 
employment persistence and impedes labour reallocation, it may also slow down the impact of some other reforms.

18. Pre-existing structural policy settings may also affect the short-run demand effects of reforms. In particular, complete financial markets should help speed up adjustment by easing firm and household liquidity constraints (Angeloni et al., 2003; Mishkin, 2007). Indeed, the possible adverse demand effects of certain structural reforms (such as a reduction in unemployment benefits) reflect in part the existence of liquidity-constrained households. In turn, the share of such households among the population is likely to be higher the more incomplete are financial markets. Among the non-liquidity-constrained households, the positive response of consumption to higher expected future income is also likely to be stronger in the presence of more complete financial markets that allow for a larger spectrum of collateral and amplify wealth effects. By allowing households to better diversify risks and insure against the potentially heterogeneous effects of reforms across socioeconomic groups, financial market completeness may also reduce the immediate distributional costs of structural reforms.

19. The short-term effects of structural reforms might also depend on countries' degree of openness through different and conflicting channels: $i$ ) greater trade openness can act as an automatic stabiliser, i.e. changes in imports dampen the aggregate demand impact of any reform-driven change in domestic demand, thereby helping stabilise the economy; ii) openness can also magnify the net external demand gains from reforms that reduce domestic prices and improve external competitiveness, helping crowd in demand more in smaller, more open economies; iii) at the same time, insofar as the real exchange rate depreciates and triggers a terms of trade loss, the associated negative effects on households' consumption may be larger in more open economies, where imports have a larger weight in domestic demand (Gomes et al., 2011).

\subsection{The role of macroeconomic policy}

20. Insofar as structural reforms imply changes in the output gap and inflation, they should in principle trigger a macroeconomic policy response. When reforms primarily boost aggregate demand, for instance by increasing expected income and allowing economic agents to bring forward future consumption gains, macroeconomic policy tightening should be called for. Reforms are often thought to raise supply more than demand though, opening up a negative output gap. ${ }^{15}$ In such cases, macroeconomic policies have the potential to "crowd in" their effects which otherwise would come through gradually as the excess supply in goods or labour markets puts downward pressure on (sticky) prices and wage inflation.

\subsubsection{Monetary policy}

21. The impact of monetary policy on the adjustment path to the new long-term equilibrium depends on the monetary policy reaction function and the strength of the monetary policy transmission channels. Regarding the former, the speed of adjustment to the new steady state associated with structural reforms that increase potential output or employment may be lower when the central bank targets money supply (Werner and Veld, 2002) and conversely increasing with the weight of inflation in its reaction function, the limiting case being a pure inflation targeting regime (Cacciatore et al., 2012, Mourougane and Vogel, 2008). As regards transmission channels, some demand components, especially business investment, are known to be more sensitive to real interest rates in the United States than in the euro area (Angeloni et al., 2003), which would in principle imply that the United States would adjust faster to the new steady state

15. As a matter of fact, widely used macroeconomic models such as GEM at the IMF and QUEST at the European Commission mostly focus on macroeconomic policy response to the potential contractionary effects of some reforms. See Cacciatore et al. (2012) for a short summary. 
than the euro area under a given monetary policy reaction. To some extent, this reflects structural policy settings. For instance, competitive and complete financial markets can strengthen the monetary policy credit channel by making consumption and investment more sensitive to interest rates. Likewise, the effectiveness of monetary policy is typically stronger under labour and product market regulations that are conducive to flexible prices and wages (see e.g. Bayoumi et al., 2004), as well as outside situations of financial market stress. However, stronger transmission of monetary policy does not necessarily need to imply faster convergence to the new post-reform equilibrium to the extent that central banks facing weaker transmission channels can react more strongly.

22. Monetary policy can be limited in various important ways in practice, making it difficult to accompany and smooth the transitional dynamics associated with structural reforms. First of all, reflecting uncertainties about the impact of reforms on potential output, monetary authorities will typically respond only to observed inflation developments - or at best indicators of future inflation - which reflect cyclical conditions only with lags. Second, participation in a fixed exchange rate regime, and in particular in a monetary union, prevents national authorities from using the monetary policy instrument in response to the cyclical impact of structural reforms. In principle, this could call for some degree of cross-country coordination, at least regarding those reforms that are common challenges across the member countries. ${ }^{16}$ Yet another obstacle to an appropriate monetary policy response to reforms is when monetary policy has hit the zero bound and has to rely on unconventional monetary tools. In such a situation, deflationary supply shocks may raise the real interest rate and thereby ultimately depress rather than stimulate the economy (a situation recently labelled the "paradox of toil", see Eggertsson, 2010). ${ }^{17,18}$ Cacciatore et al. (2012) do not find support for this view, however, because no structural reform is found have noticeable deflationary effects.

\subsubsection{Fiscal policy}

23. Fiscal policy can also cushion the short-term effect of a reform shock through both the operation of automatic stabilisers and discretionary intervention. The former is likely to be potent in reaction to structural reforms that can temporarily increase unemployment, for instance through labour shedding triggered e.g. by a reduction in job protection. Given the limitations attached to the use of monetary policy in some cases, a case also can be made for a discretionary fiscal policy response to reform - provided it can be implemented quickly enough, depending on several other factors:

- The more reforms improve public finances, the more they provide room for fiscal policy to mitigate any adverse short-run effects. In cases where the starting point for reforms is characterised by fiscal sustainability, fiscal accommodation is compelling for reforms that reduce the structural rate of unemployment in the long term, since these improve the cyclically-adjusted

16. This would allow the central bank to react as all member countries engage in structural reforms, thus implementing the "two-handed" approach at the union-wide level (Saint-Paul and Bentolila, 2000). Modelbased analyses in Everaert (2007) and Everaert and Schule (2008) confirm that synchronisation of product and labour market reforms across countries can eliminate transition costs because the monetary authority is then able to react more forcefully. Cacciatore et al. (2012) find that the short-run gains for labour market reforms are (marginally) smaller if the reforming country belongs to a large monetary union than if it has a flexible exchange rate regime. Another related argument in favour of cross-country coordination is that it limits the deterioration of relative prices and purchasing power that a country faces when implementing the reforms unilaterally, especially for a small open economy (see e.g. Gomes et al., 2011).

17. See also Laxton et al. (2006) who calibrate the IMF GEM model to the Japanese economy to study the effects of demand and supply shocks contingent on whether or not a zero interest floor is binding.

18. The more inflation expectations are anchored, the less the (expected) real interest rate is affected and the smaller this depressive effect of reforms is. 
budget balance corresponding to a given actual balance and employment rate. Hence, not changing the actual budget balance post-reform and before employment has had the time to adjust would imply an effective tightening of fiscal policy. Likewise, any adverse short-term effects of measures that directly improve the long-term sustainability of public finances, such as efficiency-enhancing public-sector reforms, can in principle be accommodated through fiscal policy.

- A related factor is the soundness of public finances at the time of reform, which can help reform implementation in at least two ways: $i$ ) the stronger the initial fiscal position, the greater the room for fiscal policy to stimulate aggregate demand if needed; ii) fiscal room for manoeuvre allows governments to compensate losers and therefore to increase the political acceptance of the reform. ${ }^{19}$

24. Structural reforms may also have positive feedback effects on the economy via their effect on public finances and long-term interest rates. Structural reforms that reduce fiscal sustainability concerns and therefore the perception of sovereign risk, e.g. pension reforms, reductions in government consumption through enhanced efficiency of public spending in health or education, may lead to a decline in interest rate premia which in turn may boost short-term growth (Giavazzi and Pagano, 1990). While there does not seem to be broad-based support for such "expansionary fiscal contractions" in the data, there is tentative evidence that fiscal retrenchment in countries that face a higher perceived sovereign default risk may be less contractionary (for recent empirical work based on historical episodes of fiscal contractions, see Sutherland et al., 2011, and Chapter 3 of IMF, 2010).

\section{Empirical approach}

25. The variety and complexity of the channels involved suggest that the short-term impact of reforms is ultimately an empirical matter. This section provides new empirical evidence on the short-term impact of product market, labour market, taxation, and pension reforms on aggregate output and labour utilisation. As already stressed in the introduction to this paper, the analysis focuses on the impact of structural reforms on observed outcomes, which makes it impossible to disentangle the contributions of changes in potential output (or employment) and changes in output (or employment) gaps. To overcome the difficulties associated with aggregate data and provide a more accurate assessment of the short-term impact of reforms, an analysis of overall GDP and labour utilisation impacts is complemented by:

1. Some analysis of the short-term impact of structural reforms on various components of aggregate demand, in particular private consumption and investment, in order to better identify the components driving the aggregate effects;

2. Some analysis of reform impacts on specific population groups (youth, prime-aged women, and seniors) and depending on their respective status in the labour market (employed, unemployed, inactive), as these are likely to behave differently in the labour market and thus to be differently affected by structural reforms.

\subsection{Methodology}

\subsubsection{Identification of "reform shocks"}

26. Reform shocks are identified using the following quantitative indicators:

19. For empirical evidence based on past reform experiences, see Duval (2008). 
- Unemployment benefits systems: two measures of benefit replacement rates (first year and average over three different durations of unemployment) and a measure of the average duration of unemployment benefits (calculated as the ratio of average replacement rates over five years to first-year replacement rates, which more precisely captures the extent to which benefits decline throughout the unemployment spell). ${ }^{20}$

- Labour taxes: a national accounts-based measure of the average tax wedge (including consumption taxes).

- Job protection: the summary OECD indexes of employment protection legislation on regular and temporary contracts.

- ALMPs: cyclically-adjusted measures of ALMP spending $^{21}$ (on training and employment incentives).

- Product market regulation: the OECD's summary index of product market regulation in seven non-manufacturing industries.

- Administrative extensions of bargaining agreements: these are captured by a measure of excess coverage of collective agreements, defined as the difference between the share of workers covered by collective agreements (coverage rate) and the share of workers that are members of a union (union density).

- The tax structure: the share of direct taxes (i.e. on income, profits, capital gains, social security contributions, payroll and workforce) in total tax revenues.

- Retirement schemes: the minimum retirement age in the (public or mandatory private) old-age pension system, and a summary measure of the implicit tax on continued work at ages 55-59 that captures deviations from actuarial neutrality.

27. A decline in any of these indicators - except the age of retirement and the cyclically-adjusted measure of spending on ALMPs - is assumed to signal a "reform". This definition is directional, in the sense that large changes in policy indicators in the opposite direction - which roughly speaking would correspond to an increase in the rigidity of labour and product markets - are ignored. It does not imply, however, any normative judgment as to what constitutes appropriate policy settings if a range of (growth and non-growth) policy objectives were to be taken into account.

28. The threshold beyond which the change in a policy indicator is assumed to signal a major policy reform is set as follows. For each policy indicator, the standard deviation of the annual change in the corresponding quantitative indicator is calculated over all available observations. In order to be consistent with the directional approach described above, and to better identify the short-term effect of "reforms", only annual declines in the corresponding quantitative indicators are considered (except for the age of retirement and the cyclically-adjusted measure of spending on ALMPs for which only increases are considered). A major reform is then assumed to have been undertaken when the change in the policy indicator in a given year exceeds 2 standard deviations. For retirement scheme reforms, this procedure is

20. This indicator varies between 0.2 and 1, where one refers to a situation where benefits do not decline during the period spent in unemployment.

21. For each component of ALMP, the amount of spending per unemployed over GDP per capita is adjusted for the economic cycle by considering the residuals of a country-specific regression of the variable on the unemployment gap (defined as the difference between the NAIRU and current unemployment). 
adapted to capture their typical phasing-in by looking at the change in the corresponding policy indicator over several years. For instance, where an increase in the minimum retirement age is observed over two consecutive years, the change in the policy variable used in the regression analysis is the total change in the retirement age over the two consecutive years for the first year of the reform and zero for the second year. ${ }^{22}$ In other policy areas, the general approach may miss certain reforms which are also implemented gradually. This is, however, a price to be paid for looking at impulse responses to reform shocks, which by definition would be inconsistent with an analysis of incremental reforms. Still, it is important to cautiously interpret the associated results as the impact of large structural reforms against the scenario of either no reform or gradual reform. The Annex provides details on the data sources and definitions along with descriptive statistics of reform shocks.

29. Table 1 presents for each country and each policy area the reform shocks identified using the above methodology. ${ }^{23}$ Liberalisation episodes in non-manufacturing industries were the most frequent structural reforms undertaken by OECD countries in the period under consideration, as already highlighted by a number of authors (Duval, 2008; Høj et al., 2006). Welfare reforms (identified here as reductions in unemployment benefit generosity, either through the level of replacement rates or through duration of benefits receipt) were frequent across English-speaking countries (Australia, Canada, the United Kingdom, Ireland, New Zealand, and the United States) as well as Nordic countries (Denmark, Norway, and Sweden) with the latter group also increasing more frequently spending on ALMPs, consistent with the activation principle and the "flexicurity" model. Job protection reforms reducing the protection of regular contracts were rarely undertaken. Reductions in job protection were mostly achieved "at the margin", by increasing flexibility in the use of temporary contracts. The resulting increase in the dualism of labour markets has been discussed in a number of studies evaluating the causes and consequences of two-tier reforms, in particular in European countries (see Boeri, 2010, for a summary). ${ }^{24}$ Reductions in the level of labour tax wedges were more frequent than reforms of the tax structure. Again, Nordic countries were most active in the former area, along with Ireland, the United Kingdom, the Netherlands, and Portugal. Tax reforms were most often not simultaneous with labour tax wedge cuts and were fully implemented over several years, consistent with the gradual reduction of labour taxation in OECD countries over the period under consideration. ${ }^{25}$ Retirement schemes reforms were also typically phased-in.

30. Based on the identification of reform shocks, the econometric approach follows the methodology outlined in Romer and Romer (2010) to estimate fiscal multipliers at various horizons based on measures of fiscal shocks. The following "reform variable" is constructed by country and year: $i$ ) when a reform

22. However, econometric results are qualitatively robust to considering alternative identification criteria for this reform shock.

23. The data on unemployment benefit schemes are available every two years. When reforms are identified, it is not a priori possible to know whether these have occurred over the first or second year (or both). In the following, it has been decided to attribute the reforms to the second year. This procedure implies that some of the effects identified in post-reform years may be lagging one year (i.e. the effects at $t+1$ may in fact reflect effects at $t+2)$.

24. The effects of job protection reforms on temporary contracts are analysed without controlling for the variation in job protection on the permanent contracts, and vice versa. Results are, however, qualitatively the same when including in the regressions the change in the alternative job protection indicator.

25. Mexico and Turkey are excluded from the sample of tax reforms (labour tax wedge and share of income taxes in overall taxes). This is due to the weight of oil-related revenues in tax revenues in the case of Mexico, which could raise the risk of falsely identifying a tax reform in concomitance with oil-related shifts in the tax structure variable. This is also due to the high inflation rates observed in these countries, which could yield large fluctuations in the tax wedge measure in the presence of imperfect indexation. In fact, applying the identification procedure of reform shocks to Mexico and Turkey delivers a suspiciously high number of tax shocks in periods of high inflation. 
shock has been identified for a particular country and year, the reform variable takes the value of the change in the associated policy indicator; ii) if no reform shock has been identified, the reform variable takes a zero value. Allowing the reform variable to take the value of the change in the underlying policy indicator results in a continuous variable that allows quantifying the impact of reform shocks, which would not be possible by considering a simple dummy variable instead. Relying on the constructed structural reform indicator variables, impulse responses to the reforms are then estimated for activity and labour market performance indicators, based on an empirical framework that refines an approach used in recent OECD work on the distributional impact of macroeconomic shocks (Ahrend et al., 2011). This framework (see below for more details) is used to identify effects of reforms up to five years after their occurrence. The analysis is also extended to explore the existence of interactions between reform variables and other structural settings as well as between reform and macroeconomic conditions.

\subsubsection{Empirical framework}

31. The empirical setup used to explore the impact of structural reforms on GDP growth and labour market performance is a simple dynamic regression framework. Dynamic models, which include some lags of the dependent variable as explanatory variables, allow an analysis of changes in economic performance without requiring the construction of a fully fledged structural model of the steady-state determinants of output and labour utilisation. In a comparable context, Cerra and Saxena (2009) and Furceri and Mourougane (2009) apply an autoregressive estimation technique to analyse the effects of financial crises on GDP growth. However, because the so-called impulse-response functions are calculated recursively in this approach, they have been criticised for being sensitive to small specification or estimation errors that always exist in practice. Teulings and Zubanov (2010) therefore suggest a related estimation technique in which the coefficients of the impulse response function are estimated directly for each time horizon, thus making the method more robust. This approach, which has also been applied in recent OECD work (Ahrend et al., 2011), is followed in the present analysis.

32. In the baseline regressions, the following equation is estimated for each of the five years after the occurrence of the reform shock $(k=1 \ldots 5)$,

$$
Y_{i, t+k}-Y_{i, t}=\alpha_{k}+\sum_{j=0}^{j=5} \beta_{k, j} \Delta Y_{i, t-j}+\theta_{k} \text { reform }_{i, t}+\sum_{j=0}^{j=5} \lambda_{h, k, j} \operatorname{crisis}_{h, k, t-j}+\gamma_{i, k}+\gamma_{t, k}+\varepsilon_{i, t, k},
$$

where $Y$ is the variable of interest (employment rate, unemployment rate, or annual growth rate of GDP, private consumption or private fixed capital formation), reform is the structural reform variable equal to the variation of the underlying policy indicator in case a reform has been identified and zero otherwise. The variables denoted crisis, $h$ are four dummies taking value one if the country experienced respectively a bank crisis, a currency crisis, a debt crisis, or a recession. 5 lags of these crisis dummies are introduced. The financial crisis dummies are taken from Laeven and Valencia (2008). The recession dummy is equal to one in years when real GDP growth is negative and zero otherwise. Controlling for recessions in the baseline equation is justified by the finding that economic crises are major facilitators of the reform process (Duval, 2008; OECD, 2009). Because economic crises are also likely to affect the dependent variables while being correlated with the probability to observe a reform shock, this procedure is aimed at reducing the potential associated omitted variable bias. $\gamma_{i k}$ and $\gamma_{t k}$ are respectively country and time fixed effects. The baseline specification however does not include any business cycle variable due to the purpose of the analysis, which is to look at the short-term impact of reforms including through the economic cycle itself. Because this could be problematic for tax-related variables, though, the corresponding regressions include the change in tax revenues over GDP as a control variable.

33. The estimated coefficients $\theta_{\mathrm{k}}$ give the response at horizon $\mathrm{k}$, and together they yield the impulse response function. While the presence of a lagged dependent variable and country fixed effects may in 
principle bias the estimation of the $\beta$ s in short samples (Nickell, 1981), the length of the time dimension mitigates any possible concerns about such bias, given that the finite sample bias is of the order of $1 / T$, where $\mathrm{T}$ is the length of the time dimension (Greene, 2000) ${ }^{26}$ Robust standard errors are clustered at the country level. ${ }^{27}$ Parameter estimates of neither the autoregressive $\beta$ s nor the fixed effects $\gamma$ or the crisis dummies are of particular interest for the analysis. In the discussion of the empirical result, impulse response coefficients $\theta_{1} \ldots \theta_{5}$ are reported in bar charts, with each bar representing the size of the estimated response in years 1 to 5 following the reforms, and statistical significance is indicated by stars in each bar.

34. The empirical analysis also explores whether macroeconomic conditions shape the short-term impact of reforms. This is done in two ways: $i$ ) by extending the baseline specification to explore whether the impact of structural reforms varies depending on the cyclical position of the economy; ii) by introducing indicators of macroeconomic policy settings in the regression framework, both as control variables and in interaction with the reform shock. In practice, indicators of cyclical conditions or macroeconomic policy settings - denoted by $P_{i t}$ - are interacted with the reform shock variables as follows:

$$
\begin{aligned}
& Y_{i, t+k}-Y_{i, t}=\alpha_{k}+\sum_{j=0}^{j=5} \beta_{k j} \Delta Y_{i, t-j}+\theta_{k} \text { reform }_{i t}+\delta_{k} \text { reform }_{i t} \times P_{i t}+\rho_{k} P_{i t} \\
& +\sum_{j=0}^{j=5} \lambda_{h, k, j} \text { crisis }_{h, k, t-j}+\gamma_{i k}+\gamma_{t k}+\varepsilon_{i t k} .
\end{aligned}
$$

35. The cyclical position is measured either by the unemployment gap (for the labour market dependent variables) or by the output gap (for the investment and consumption growth dependent variables) prevailing when the reform is introduced. Macroeconomic policy settings are also measured just prior to the reform. While it would have been relevant to focus on macroeconomic policy responses to the reform shocks, this was not possible in the current econometric setting. Indeed, including measures of coincident or subsequent macroeconomic policy changes in the regression analysis raises a major endogeneity issue. ${ }^{28}$ Against this background, the analysis focuses instead on the potential for macroeconomic policy to react to the reform shock. Specifically, the following measures are considered in $t-1$, where $t$ is the reform year: $i)$ the nature of the de facto exchange rate regime as a measure of the capacity of monetary authorities to respond to a reform shock (taken from the classification of Levy-Yeyati and Sturzenegger, 2005); ii) the capacity of discretionary fiscal policy to respond to a reform shock, measured alternatively by the cyclically-adjusted primary balance or the difference between the cyclicallyadjusted primary balance and the cyclically-adjusted primary balance required to stabilise the debt-to-GDP ratio.

26. Teulings and Zubanov (2010) use specifications with and without the lagged difference terms. These terms were kept in to control for a maximum of unobserved influences that are not related to reform shocks. Results are qualitatively unchanged for a different number of lagged difference terms.

27. The assumption of no cross sectional dependence could be problematic if countries coordinated reforms. In practice, this might be relevant for some EU countries where network sector deregulation might have resulted from the implementation of EU-level directives. However there is no easy way to address this issue, particularly so while still clustering standard errors at the country level as required.

28. This prior is confirmed by an estimated negative effect of monetary expansion -- measured by a decrease in the short-term real interest rates -- on short-run growth. This counter-intuitive result clearly reflects an endogeneity bias, as central banks have historically responded to business cycle fluctuations by implementing counter-cyclical macroeconomic policy. 
Table 1. Overview of the reform database

\begin{tabular}{|c|c|c|c|c|c|c|c|c|c|c|c|c|c|}
\hline Country & $\begin{array}{l}\text { Decline in initial UB } \\
\text { Replacement Rate }\end{array}$ & $\begin{array}{l}\text { Decline in 5-year } \\
\text { Average UB } \\
\text { Replacement Rate } \\
\end{array}$ & $\begin{array}{l}\text { Decline in "UB } \\
\text { Duration" }\end{array}$ & \begin{tabular}{|c} 
Decline in Job \\
Protection on \\
Regular \\
Contracts \\
\end{tabular} & \begin{tabular}{|c|} 
Decline in Job \\
Protection on \\
Temporary \\
Contracts \\
\end{tabular} & $\begin{array}{c}\text { Decline in } \\
\text { excess union } \\
\text { Coverage }\end{array}$ & $\mid \begin{array}{c}\text { Decline in Labour Tax } \\
\text { Wedge }\end{array}$ & $\begin{array}{c}\text { Decline in share } \\
\text { Income tax in tax } \\
\text { revenues }\end{array}$ & $\begin{array}{l}\text { Decline in product } \\
\text { market regulation }\end{array}$ & $\begin{array}{c}\text { Increase in minimum } \\
\text { retirement age }\end{array}$ & $\begin{array}{c}\text { Decline in Implicit tax } \\
\text { rate on continued } \\
\text { work }\end{array}$ & $\begin{array}{l}\text { Increase in Spending } \\
\text { on ALMP in Training }\end{array}$ & $\begin{array}{c}\text { Increase in Spending } \\
\text { on ALMP in } \\
\text { Employment } \\
\text { Incentives }\end{array}$ \\
\hline \begin{tabular}{|l} 
Australia \\
\end{tabular} & & 1983,1993 & & & & & 1989,2006 & 1983 & 1996 & & & & 1996, 1998, 2006 \\
\hline Austria & 1983,1993 & & & & & & & & $1999,2000,2001$ & & & $1986,1999,2006$ & \\
\hline Belgium & & & & & 1997 & & & & 1991, 1995 & & & & \\
\hline Canada & 1997,2005 & & & & & & & & 1988 & & & & \\
\hline Switzerland & & 2003 & & & & 2000 & & 1985 & 1998,2005 & & & 1996,1997 & 1998 \\
\hline & & & & & & & & & & & & & \\
\hline \begin{tabular}{|l} 
Czech Republic \\
\end{tabular} & & & & & & & 1996 & & $2001,2002,2005$ & & & & \\
\hline Germany & & 2005 & 2005 & & 1997 & 2000 & 1986 & & 1990,1999 & & & 1992 & \\
\hline Denmark & 1995 & 2001 & 2001 & & 1995 & & 2001,2006 & & $1989,1995,2001$ & & & $1995,1996,1998$ & $1993,1997,2000$ \\
\hline Spain & 1985, 1993 & & & 1994 & & & 1986 & 1981, 1986 & 1999, 2002, 2005 & & & & $\begin{array}{l}\begin{array}{l}\text { 1986, } 1992,1998, \\
1999\end{array}\end{array}$ \\
\hline Estonia & & & & & & & & & & & & & \\
\hline \begin{tabular}{|l} 
Finland \\
France
\end{tabular} & & & 1985 & & & & $1987,1995,1997$ & & $\begin{array}{l}1986,1994,1995 \\
1989,1999,2002,\end{array}$ & & 1982-1983 & 1997 & \\
\hline $\begin{array}{l}\text { Irrance } \\
\text { United Kingdom }\end{array}$ & 1983,1999 & & & & & \begin{tabular}{|l}
1990,2000 \\
\end{tabular} & 1989 & 1980 & $\begin{array}{l}2003,2005 \\
1990,1993\end{array}$ & & & 1989 & \\
\hline Greece & 1993 & & & & 2003 & & & 1986, 1992, 1996 & $2001,2002,2005$ & & & 1995 & 2001 \\
\hline Hungary & & & & & & & 2002,2003 & 1992,1995 & $2001,2002,2004$ & & & & \\
\hline \begin{tabular}{|l|} 
Ireland \\
\end{tabular} & \begin{tabular}{|l|l|}
$1985,1989,1995$ \\
\end{tabular} & 1995 & & & & & $1989,1995,1998$ & 1989 & 1988,1999 & & & 2001 & 1999 \\
\hline Iceland & & & & & & & & & 2003,2005 & & & & \\
\hline |taly & & & & & & & & 1994,1998 & $\begin{array}{l}\text { 1993, 1999, 2001, } \\
2005\end{array}$ & 1996-1997 & 1996-1997 & 1991 & 2001, 2002 \\
\hline Japan & & & & & & & & & 1988,1990 & & & & \\
\hline Korea & & & & 1998 & & & & $1980,1991,1999$ & 2001 & & & & \\
\hline Luxembourg & & & & & & & & 1980,2004 & 2001,2005 & & & & $1988,1990,2005$ \\
\hline Mexico & & & & & & & & & & & & & \\
\hline \begin{tabular}{|l} 
Netherlands \\
\end{tabular} & & 2005 & 2005 & & 1999 & & $1994,1998,2001$ & 1998 & $1992,1994,1999$ & & & & 1997,1998 \\
\hline Norway & & 2003 & 2003 & & & & $2000,2005,2006$ & 1992 & 1984,1991 & & & $1989,1994,1995$ & \\
\hline New Zealand & & & & & & 2000 & & $1983,1986,1987$ & $\begin{array}{l}1983,1988,1991, \\
1996\end{array}$ & 1990-1999 & & 1986, 1987 & 1988 \\
\hline Poland & & & & & & & & 1992, 1993, 2002 & $\begin{array}{l}1999,2000,2001, \\
2005\end{array}$ & & & & \\
\hline Portualat & & & & & & & 1986 & 1980,1986 & 1987 & & 1994-1995 & $\begin{array}{l}1990,1991,1992, \\
1998\end{array}$ & 19981999 \\
\hline Slovak Republic & 2005 & & & & & & & 2004 & 2005 & & & & 1997 \\
\hline Slovenia & & & & & & & & & & & & & \\
\hline Sweden & 1999 & & & & 1993 & & 2000,2007 & 1987 & 1991, 1992, 1996 & & 1990-1993 & $\begin{array}{l}1987,1988,1998, \\
2001\end{array}$ & $\begin{array}{l}\begin{array}{l}1987,1988,1989, \\
1998,1999,2000, \\
2006\end{array} \\
\end{array}$ \\
\hline Turkey & & & & & & & & & & & & & \\
\hline \begin{tabular}{|l} 
United States \\
\end{tabular} & 1987 & & & & & & 2002 & 2002 & 1980 & & & & \\
\hline
\end{tabular}


36. Similarly, in order to investigate whether the short-term effects of reforms are shaped by other institutional settings, pre-reform institutions (denoted by $Z_{t-1}$ ) are also interacted with reform shocks as follows:

$$
\begin{aligned}
& Y_{i, t+k}-Y_{i, t}=\alpha_{k}+\sum_{j=0}^{j=5} \beta_{k j} \Delta Y_{i, t-j}+\theta_{k} \text { reform }_{i t}+\delta_{k} \text { reform }_{i, t} * Z_{i, t-1}+\rho_{k} Z_{i, t-1} \\
& +\sum_{j=0}^{j=5} \lambda_{h, k, j} \text { crisis }_{h, k, t-j}+\gamma_{i k}+\gamma_{t k}+\varepsilon_{i t k} .
\end{aligned}
$$

37. Due to the lack of time variation of some of the institutional variables analysed, the direct effect of the institutional variables cannot always be included in the associated regressions. The focus is on the coefficients $\theta$ and $\delta$ that measure the response of the outcome variable to the reform shock and its interaction with different institutional and macroeconomic settings, looking up to five years into the future after the occurrence of a macroeconomic shock. ${ }^{29}$

38. This empirical approach is subject to several limitations that require some caution in interpreting the results and extrapolating them into policy conclusions:

- Several of the structural reforms considered here may be found to have limited macroeconomic incidence in the short run due to their relatively small size rather than due to the absence of any effect. Major reforms are rare events. ${ }^{30}$ Also, as recalled above, many reforms have been incremental in nature, a feature which the current empirical approach cannot fully capture. As a result, the approach may be seen as "biased" against finding significant effects; ${ }^{31}$

- The approach does not identify the specific channels through which structural reforms may affect the economy;

- There is in principle the risk that the model fails to properly identify the effect of a particular reform by omitting to control for simultaneous reforms in other fields. This risk appears to be limited in practice, however, since correlations between the various reform variables are very low and statistically insignificant in the vast majority of cases (see Table A.4 in the Annex). ${ }^{32}$

\section{Results}

39. This section presents the baseline results on the short-term effects of labour market, welfare, tax and product market reforms on labour utilisation and growth in output, investment, and private

29. The baseline results are submitted to several sensitivity checks that broadly confirm their robustness (see section 3.4).

30. At the same time, though, the current methodology reduces the potential endogeneity of reforms, as relying on sufficiently stringent criteria to define reform shocks makes it less likely that policy changes are systematically correlated with other developments affecting the outcome (dependent variable) of interest.

31. This is particularly true as regards the effects of product market reforms, which have been historically gradual and for which only industry indicators are available in a time series dimension and for seven nonmanufacturing sectors.

32. Introducing all reform shocks simultaneously is also unwarranted as it substantially reduces the size of the sample and regressions' degrees of freedom. 
consumption. Table 2 provides a summary while Table A5 in the Annex provides detailed regression results.

\subsection{Labour market and welfare reforms}

40. In a nutshell, and in some cases perhaps surprisingly, the analysis suggests that the short-term effects of labour market and welfare reforms are typically positive or (statistically) insignificant, without any supportive evidence of aggregate costs - although there can be distributional consequences which are only briefly and incompletely covered below. It should be noted, however, that positive or null effects could still imply that structural reforms create short-term economic slack insofar as actual output increases less than potential. Detailed findings can be summarised as follows:

- $\quad$ Reductions in unemployment benefit replacement rates appear to have on average fairly quick positive effects on employment. For example, a reduction in the initial unemployment benefit replacement rate of around 8 percentage points (corresponding to the median reform in the estimation sample) would translate into a 0.5 percentage point increase in the employment rate after three years and into an almost 1 percentage point increase after five years (Figure 1). Likewise, a median reduction in the average replacement rate (over three different durations of unemployment) of around 4.5 percentage points leads to a 0.1 percentage point increase in the employment rate after one year. This roughly corresponds to one-tenth of the long-run effect estimated by Bassanini and Duval (2006). Consistent with their employment effects, such reforms are also found to be associated with stronger investment and output growth, raising GDP growth on average by more than 1 percentage point after five years, ceteris paribus.

Figure 1. Change in aggregate employment following a reduction in the initial unemployment benefit replacement rate

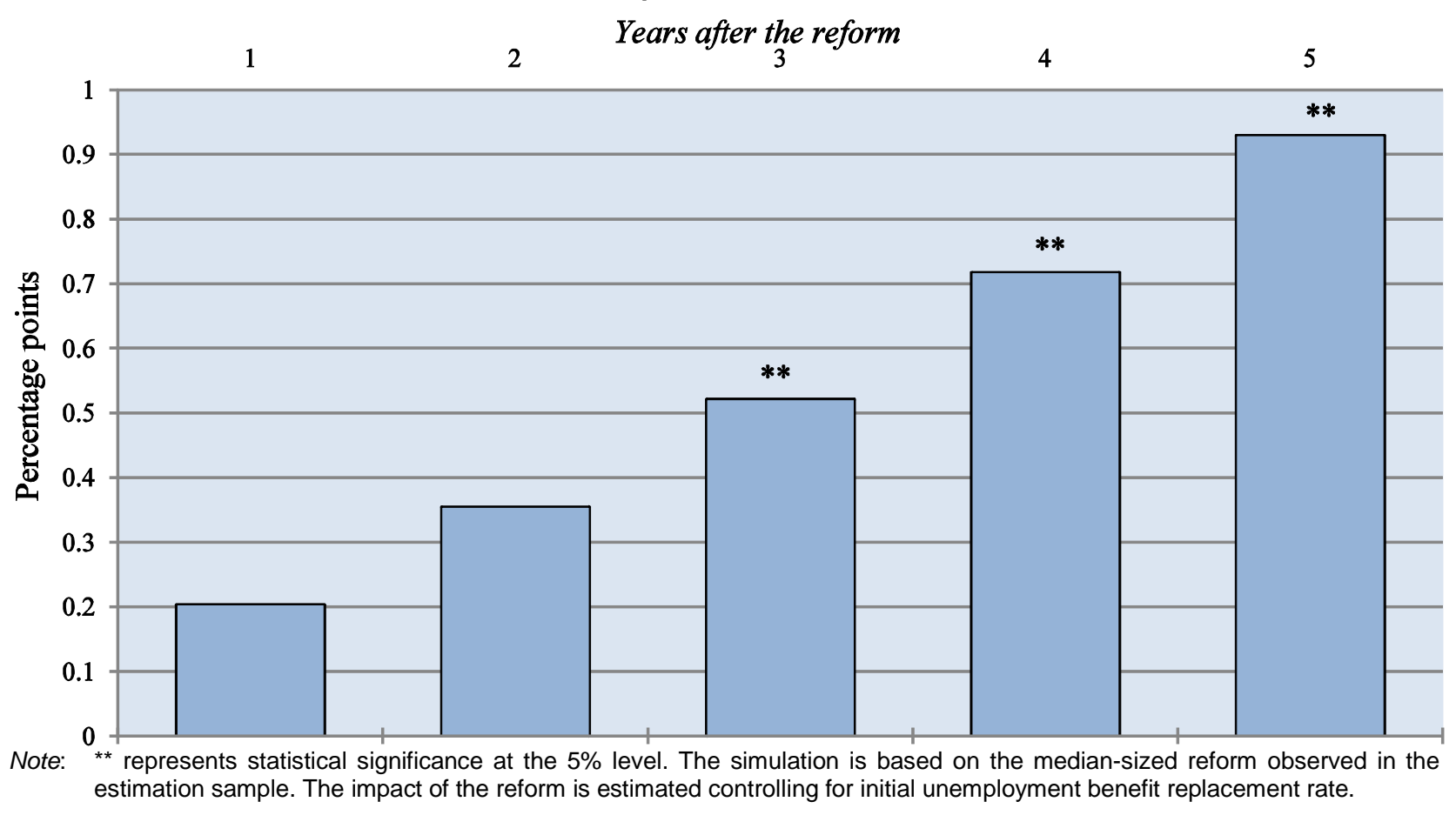

- Reductions in benefit duration - more precisely, steeper declines in benefits throughout the unemployment spell -also have positive employment effects on average over a three-year 
horizon, but these effects are found to disappear after five years. Unemployment is found to decline more quickly than employment increases, and the decline is particularly marked among young people (Figure 2). As an illustrative example, the estimates suggest that a decrease in benefit duration similar to that implemented in Denmark in 2001 - corresponding approximately to the median-sized reform over the three decades - could reduce the unemployment rate of youths by more than $1 \frac{1}{2}$ percentage points after three years.

Figure 2. Change in youth unemployment following a reduction in unemployment benefit duration

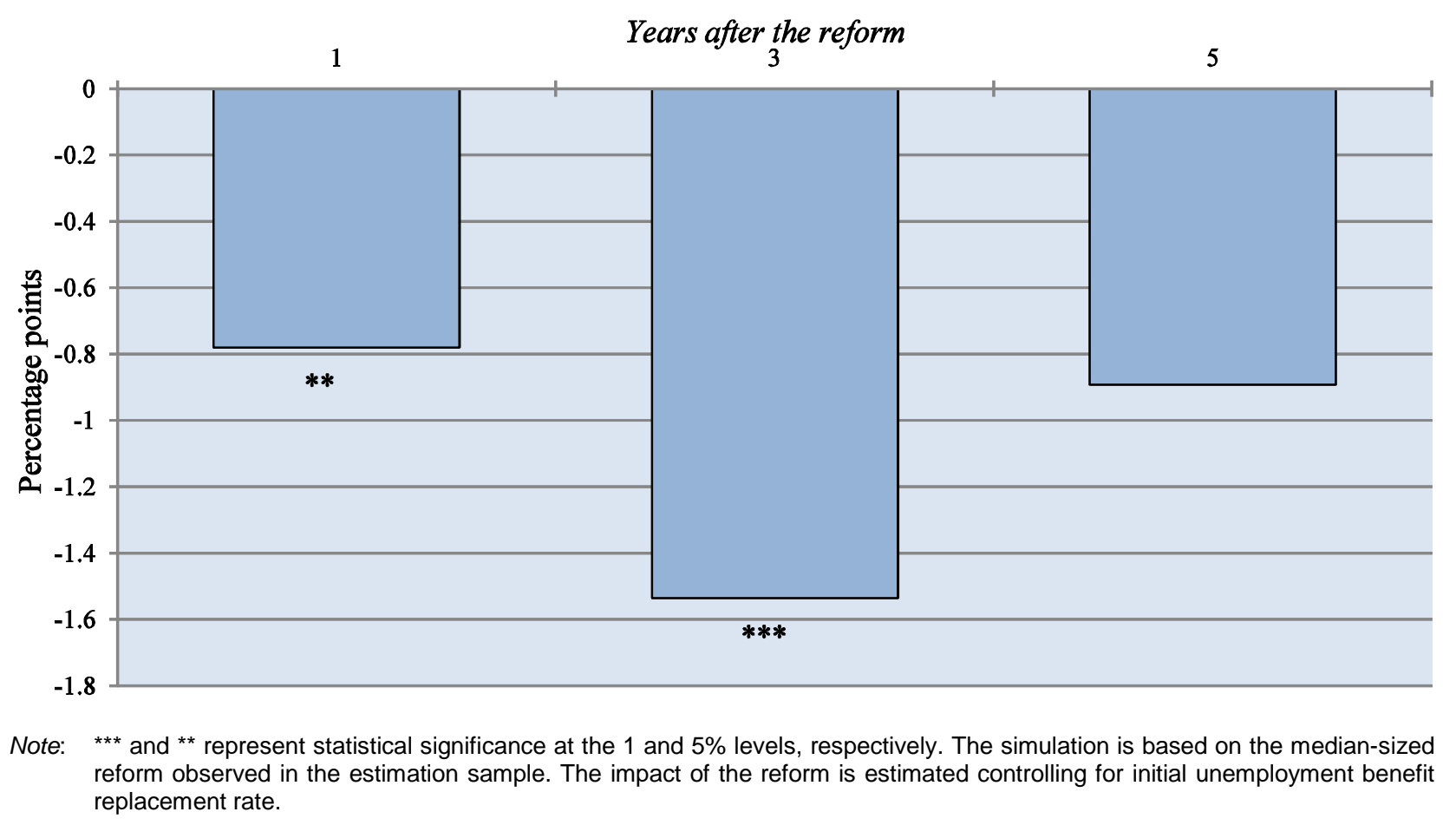

- Unemployment benefit reforms seem to have negative short-term effects on the labour market outcomes of specific groups of the labour force, in particular older workers. For instance, reducing unemployment benefit duration is associated with a reduction in senior employment. To the extent that older age groups are over-represented among the long-term unemployed, this effect may be driven by labour force withdrawal and therefore by discouragement effects possibly coupled with early retirement in countries where this has been possible. Moreover, reducing the initial unemployment benefit replacement rate is found to increase female unemployment, although very temporarily. 
ECO/WKP(2012)26

Table 2. Short-term impact of structural reforms: summary table

\begin{tabular}{|c|c|c|c|c|c|c|c|c|c|c|c|c|c|}
\hline & \multirow{3}{*}{$\begin{array}{c}1 \\
\text { Decline in } \\
5 \text {-year } \\
\text { Average UB } \\
\text { Replacement } \\
\text { Rate }\end{array}$} & \multicolumn{2}{|c|}{2} & 3 & 4 & 5 & 6 & 7 & 8 & 9 & 10 & 11 & 12 \\
\hline & & \multicolumn{2}{|c|}{$\begin{array}{l}\text { Decline in initial UB } \\
\text { Replacement Rate + } \\
\text { Decline in UB Duration" }\end{array}$} & \multirow[t]{2}{*}{$\begin{array}{c}\text { Decline } \\
\text { in Job } \\
\text { Protection } \\
\text { on Regular } \\
\text { Contracts }\end{array}$} & \multirow{2}{*}{$\begin{array}{c}\text { Decline in } \\
\text { Job } \\
\text { Protection } \\
\text { on } \\
\text { Temporary } \\
\text { Contracts } \\
\end{array}$} & \multirow[t]{2}{*}{$\begin{array}{c}\text { Decline } \\
\text { in Labour } \\
\text { Tax } \\
\text { Wedge }\end{array}$} & \multirow[t]{2}{*}{$\begin{array}{l}\text { Decline in the } \\
\text { Share of } \\
\text { Income Tax in } \\
\text { Total Tax } \\
\text { Revenues }\end{array}$} & \multirow{2}{*}{$\begin{array}{c}\text { Increase } \\
\text { in } \\
\text { Spending } \\
\text { on ALMP } \\
\text { in } \\
\text { Training } \\
\end{array}$} & \multirow[t]{2}{*}{$\begin{array}{l}\text { Increase in } \\
\text { Spending on } \\
\text { ALMP in } \\
\text { Employment } \\
\text { Incentives }\end{array}$} & \multirow[t]{2}{*}{$\begin{array}{c}\text { Reduction } \\
\text { of "excess" } \\
\text { coverage of } \\
\text { collective } \\
\text { bargaining }\end{array}$} & \multirow[t]{2}{*}{$\begin{array}{l}\text { Decline in } \\
\text { Product } \\
\text { Market } \\
\text { Regulation }\end{array}$} & \multirow[t]{2}{*}{$\begin{array}{c}\text { Increase in } \\
\text { Minimum } \\
\text { Retirement } \\
\text { Age }\end{array}$} & \multirow[t]{2}{*}{$\begin{array}{c}\text { Decline in } \\
\text { Implicit } \\
\text { Tax on } \\
\text { Continued } \\
\text { Work }\end{array}$} \\
\hline & & $\begin{array}{c}\text { Decline in } \\
\text { initial UB } \\
\text { Replacement } \\
\text { Rate }\end{array}$ & $\begin{array}{l}\text { Decline } \\
\text { in UB } \\
\text { Duration }\end{array}$ & & & & & & & & & & \\
\hline Aggregate employment & + & ++ & + & & -- & & & & ++ & & & & \\
\hline Youth & & ++ & + & & - & & & & + & & & & \\
\hline Women & & +++ & + & & & & & ++ & ++ & & ++ & & \\
\hline Senior & & ++ & - & & & + & & ++ & ++ & ++ & & --- & -- \\
\hline Aggregate unemployment & - & & - & -- & & & - & - & -- & & & & \\
\hline Youth & -- & & -- & -- & & & - & - & & - & & & \\
\hline Women & + & + & & --- & + & & & - & -- & -- & - & & \\
\hline Senior & ++ & -- & & & & & & & & -- & & ++ & \\
\hline Aggregate participation & + & ++ & + & & -- & & & & ++ & + & ++ & & \\
\hline Youth & + & & + & & - & & + & & & + & & & \\
\hline Women & + & ++ & & & - & & ++ & & & & ++ & & \\
\hline Senior & & & & & & + & & ++ & + & ++ & & --- & -- \\
\hline GDP growth rate & & ++ & ++ & & - & & & & & + & - & ++ & ++ \\
\hline Consumption growth rate & + & & ++ & & -- & & & -- & & + & + & ++ & \\
\hline Private Investment growth rate & + & + & + & ++ & - & & + & & & & - & $-\&+$ & + \\
\hline
\end{tabular}

Note: The entries of this table rely on the baseline regressions. + denotes a significant positive short-run impact while - denotes a negative one. +(-), ++ (--) and +++(---) denote a positive (negative) impact which is significant in one year, two to four years, and over the whole period under consideration, respectively. $+\&-$ denotes sign reversals in the estimated effect over the period considered. 
- Only few OECD countries reduced job protection on regular contracts over the sample period. Empirical results in this area are therefore based on a handful of reform experiences and should be interpreted with care. ${ }^{33}$ Keeping this limitation in mind, reducing job protection on regular contracts is not found to have any statistically significant effects on aggregate employment, consistent with theoretical and empirical priors. But in the short run, empirical results tentatively suggest that reforms of job protection on regular contracts reduce unemployment, benefiting primarily youth and women (Figure 3).

Figure 3. Change in female unemployment following a reduction in job protection on regular contracts

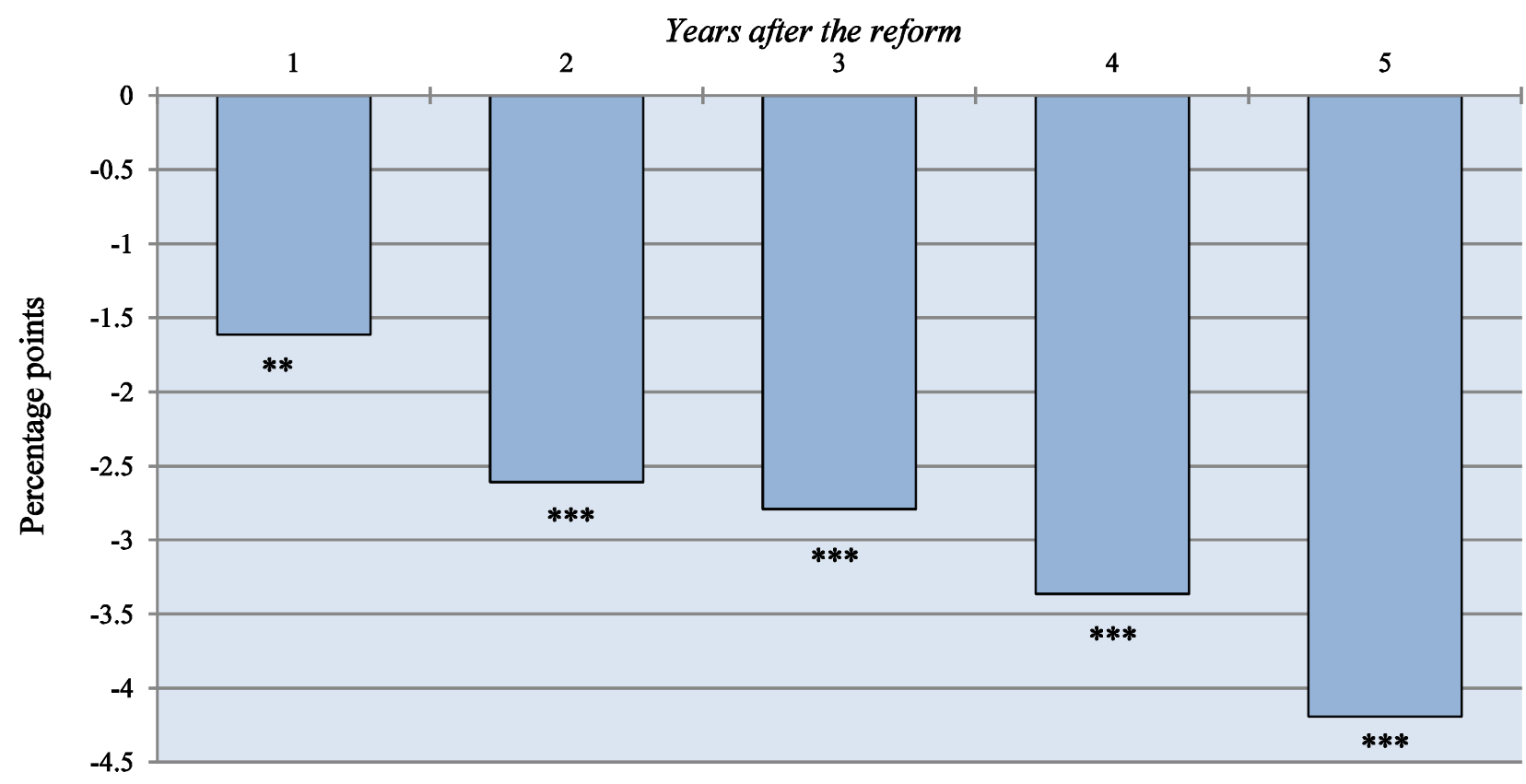

Note: ${ }^{* \star *}$ and ${ }^{* *}$ represent statistical significance at the 1 and $5 \%$ levels, respectively. The simulation is based on the median-sized reform observed in the estimation sample.

- By contrast, reducing job protection on temporary contracts is found to reduce employment in the short to medium term, with a decrease in the overall employment rate of 0.2 percentage points in the year following a median reform and of 2 percentage points five years after (Figure 4). ${ }^{34}$ Hence there seems to be no empirical evidence of "honeymoon effects" (Boeri and Garibaldi, 2007) in these estimates. This result is consistent with recent findings by Blanchard and Landier (2002) and Bentolila et al. (2010), who argue that two-tier reforms of job protection may in fact increase the equilibrium unemployment rate by increasing unemployment turnover. In line with this argument, unreported results indicate that reforms of job protection on temporary contracts do increase unemployment turnover (by raising both entry into and exit from unemployment). This broadly confirms previous analysis, including by the OECD, which already highlighted the

33. At the same time, as presented in section 3.4 below, findings reported here are robust to the use of a less stringent reform identification criterion, and therefore the inclusion of a higher number of (arguably smaller-sized) reforms.

34. The simulation assumes a median-sized reform, i.e. a reduction of 1.7 points in the associated indicator of employment protection legislation on temporary contracts (corresponding roughly to the size of the reform identified for Greece in 2003). 
weaknesses of partial job protection reform strategies. ${ }^{35}$ Consistent with their negative employment effects, such reforms are also associated with lower GDP, consumption, and investment growth rates.

Figure 4. Change in aggregate employment following a reduction in job protection on temporary contracts

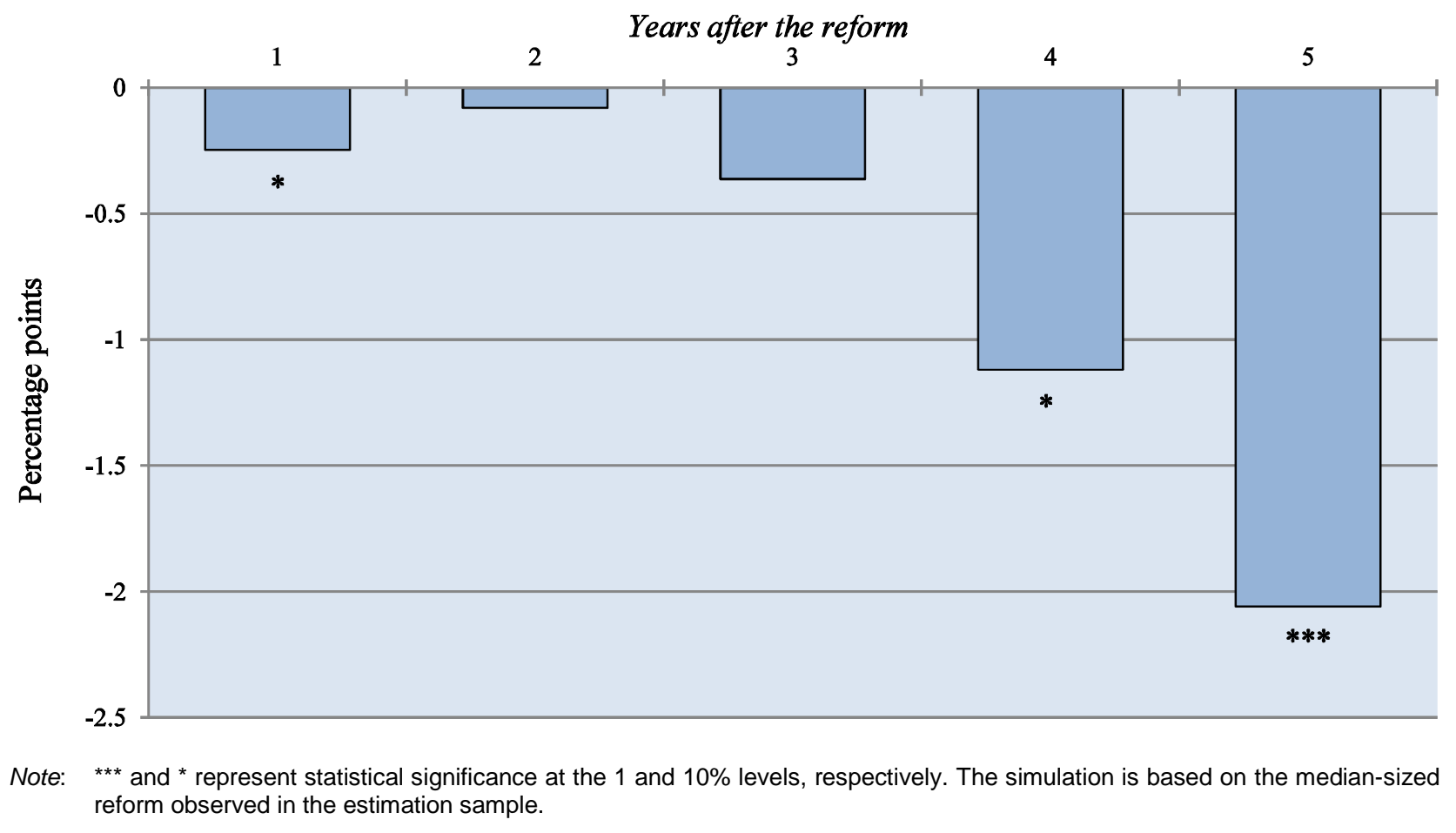

- Reforms of old-age and early retirement schemes have unexpected negative effects on senior employment and participation, at odds with the strong and significant positive long-run impact found in previous OECD work (Duval, 2003). This finding holds for both increases in minimum retirement ages and declines in implicit taxes on continued work. One tentative interpretation could be that such reforms may in the very short term push seniors out of the labour force through anticipation effects. ${ }^{36}$

- The effects of reforms of ALMPs are difficult to identify based on changes in expenditures, largely due to the cyclicality and therefore the endogeneity of the ALMP spending measures. Indeed, econometric analysis carried out for OECD countries over the period 1985-2006 (OECD, 2009) indicates that these expenditure categories typically grow when cyclical unemployment increases. The empirical analysis attempts to address this issue by removing the cyclical

35. See De Serres et al. (2012) for a recent assessment and various editions of the OECD Employment Outlook (for instance OECD, 2010).

36. However this interpretation is difficult to reconcile with an estimated growing (rather than shrinking) negative effect as time goes by. 
component from the policy indicator. ${ }^{37}$ Keeping in mind that this adjustment may be imperfect, the results suggest that increases in spending on employment incentives (Figure 5), as well as on training, increase employment in the short term, particularly among women as regards training measures (Figure 6). By contrast, the overall short-term impact of ALMP spending as well as that of some sub-categories such as spending on public employment services and administration (PES) and direct job creation, is found to be negative on both labour market outcomes and output. These counter-intuitive results (not reported) are probably driven by the fact that these spending categories are relatively more pro-cyclical (especially for the PES category).

Figure 5. Change in aggregate employment following an increase in spending on ALMP employment incentives

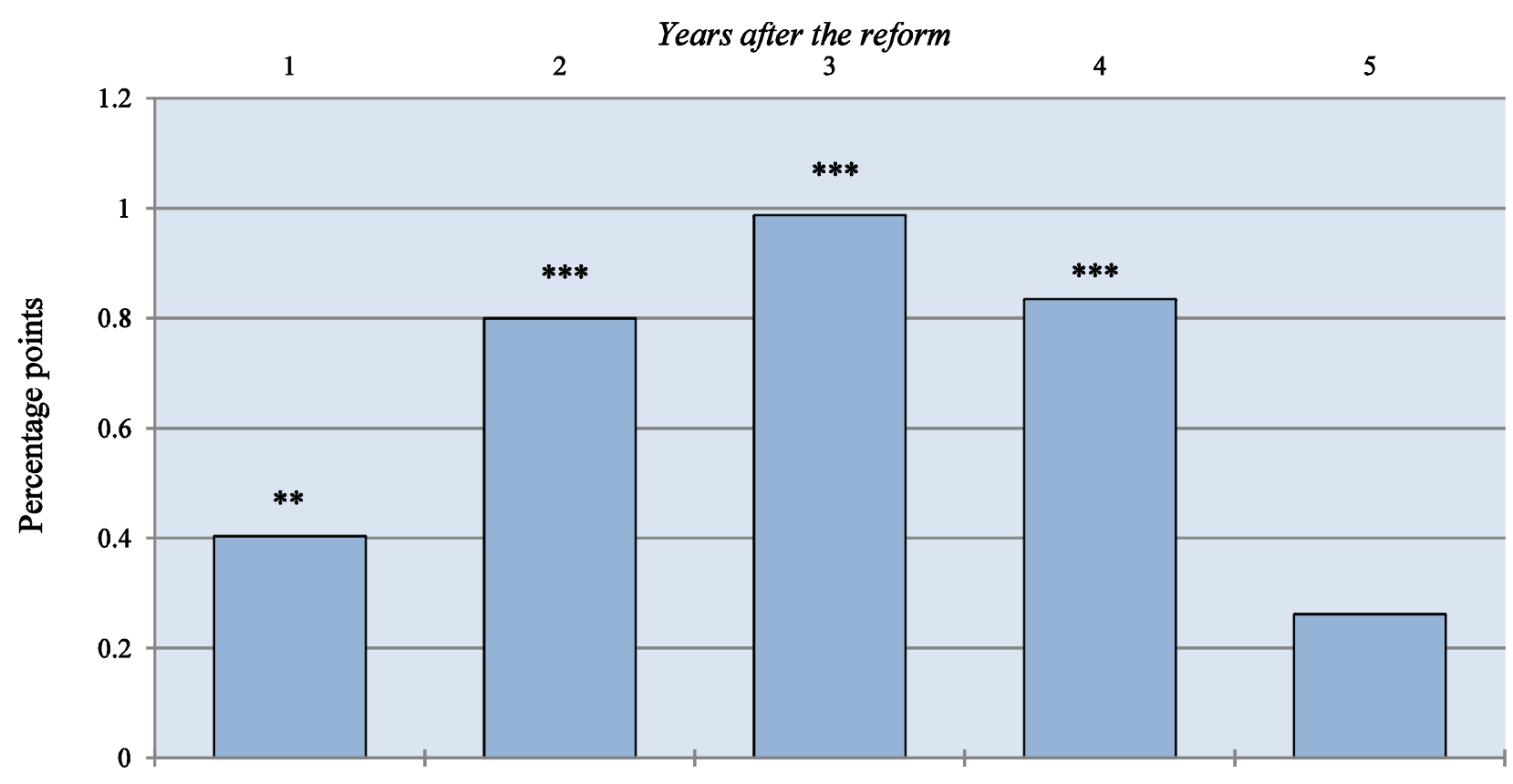

$\star \star \star$ and * represent statistical significance at the 1 and $10 \%$ levels, respectively. The simulation is based on the median-sized reform observed in the estimation sample.

37. In order to remove the cyclical component, the underlying policy indicator is calculated as the residuals from a country-specific regression of spending per unemployed as a share of GDP per capita - the usual spending measure used in the literature - on the unemployment gap and its lag. Variants of this method deliver similar results as those that are presented here. 
Figure 6. Change in female employment following an increase in spending on ALMP in training

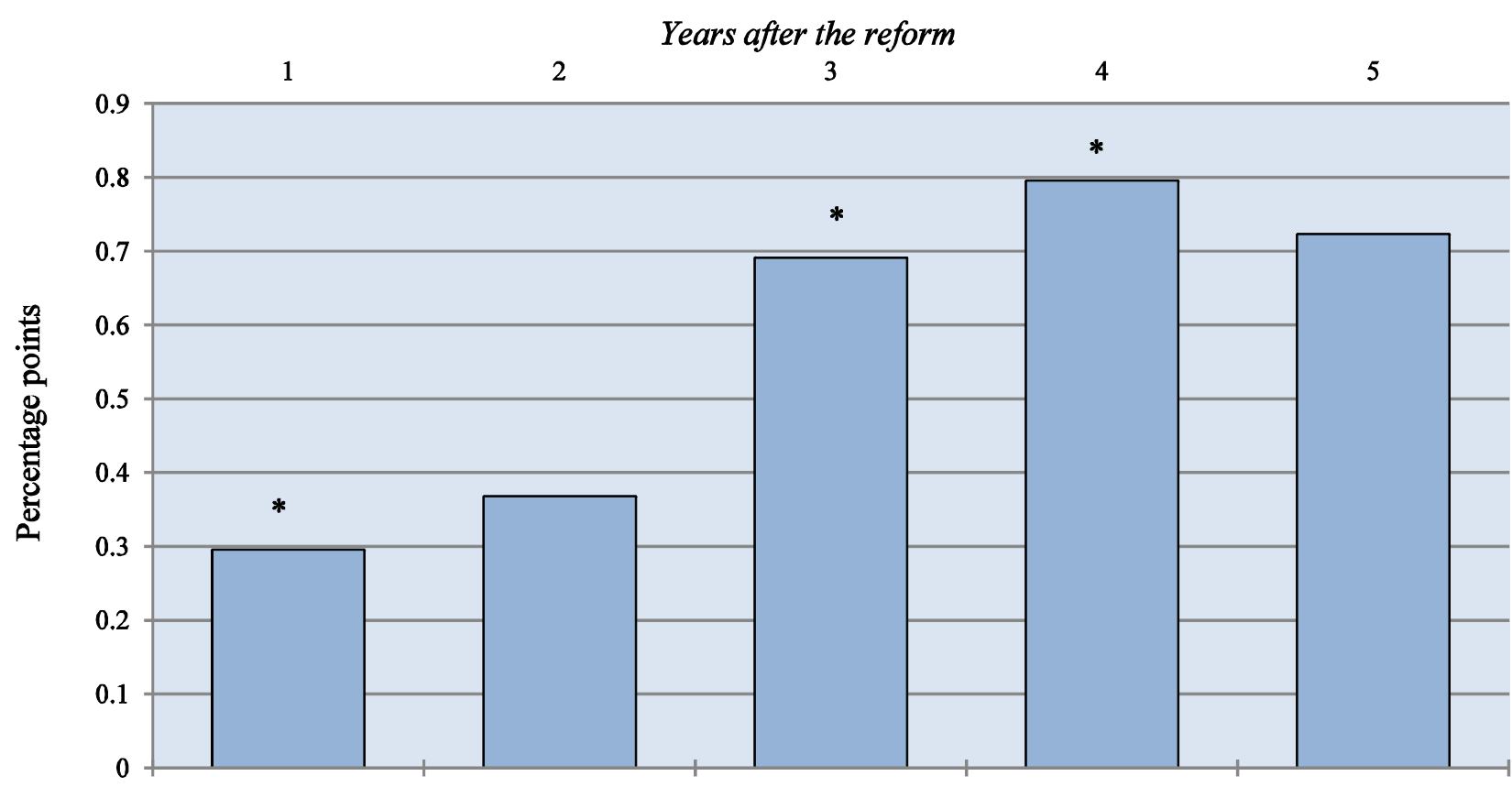

Note: * represents statistical significance at the $10 \%$ level. The simulation is based on the median-sized reform observed in the estimation sample.

- Reductions of "excess" coverage of collective bargaining, which are interpreted here as capturing reductions in administrative extensions of collective agreements, have beneficial effects on unemployment, particularly for females (Figure 7). For example, taken at face value, the results suggest that reducing 'excess" coverage of collective bargaining in Portugal to the level prevailing in Germany - i.e., a reduction of 11.3 percentage points which is equivalent to the median reform over the three decades - might reduce female unemployment by 0.44 percentage points after three years. 
Figure 7. Change in female unemployment following a decline in excess bargaining coverage

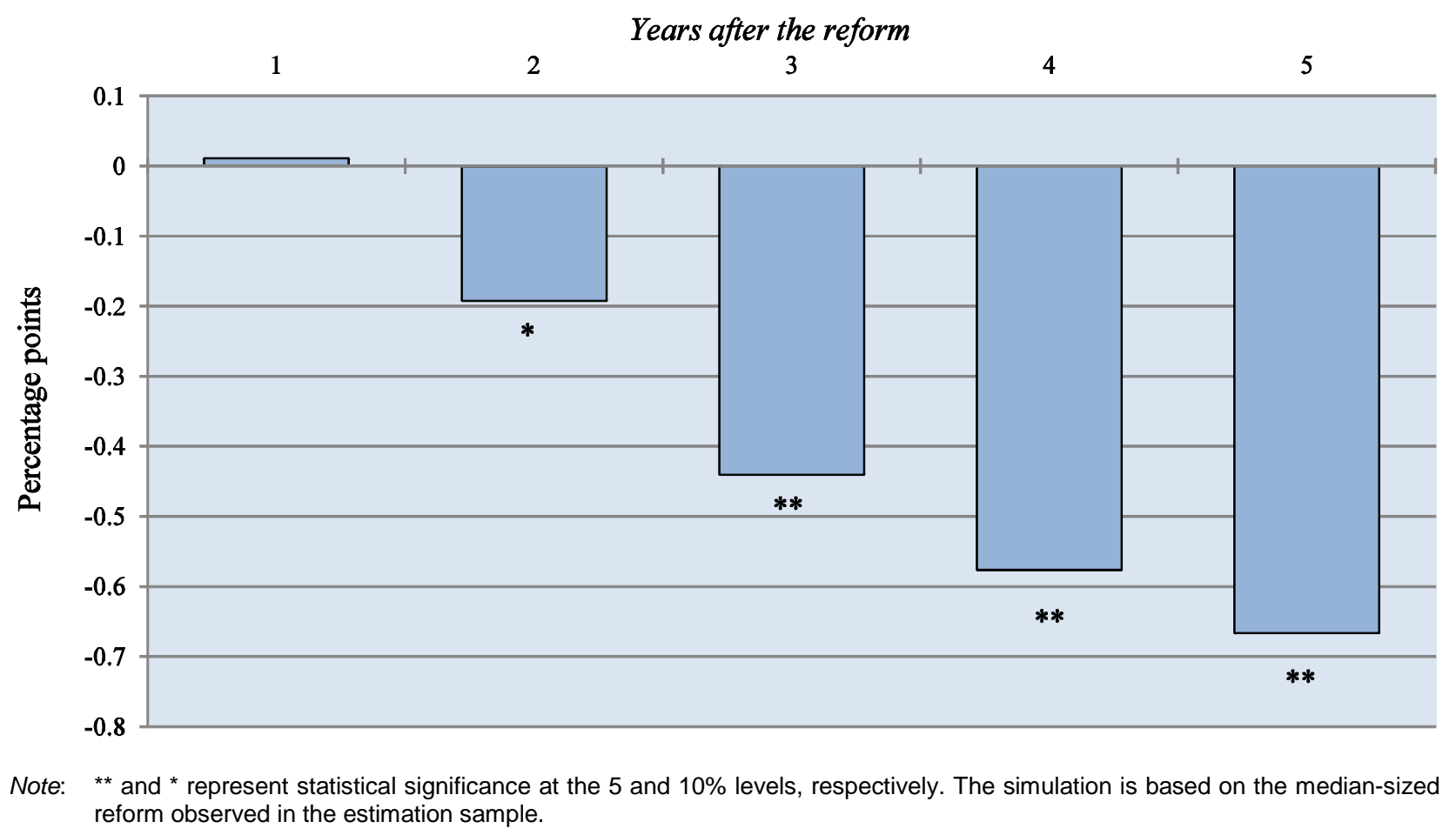

\subsection{Tax reforms}

41. The empirical analysis delivers mixed results on the potential for tax reforms to provide quick gains: ${ }^{38}$

- On the one hand, reducing the share of direct taxes in overall tax revenue is found to quickly reduce unemployment, particularly for youth. In the medium run, such reforms also trigger stronger female (Figure 8) and youth participation, although these effects are eventually found to fade away. Hence, making the tax structure more employment-friendly seems to be associated with positive labour supply and labour demand effects. Moreover, consistent with the view that such reforms make the tax structure more investment-friendly by shifting the tax burden away from labour and capital, they are also associated with higher private investment growth.

38. The baseline regressions featuring tax reforms control for changes in the overall tax burden. However, the results are not sensitive to such control. 
Figure 8. Change in female labour force following a reduction in share of income taxes in total tax revenues

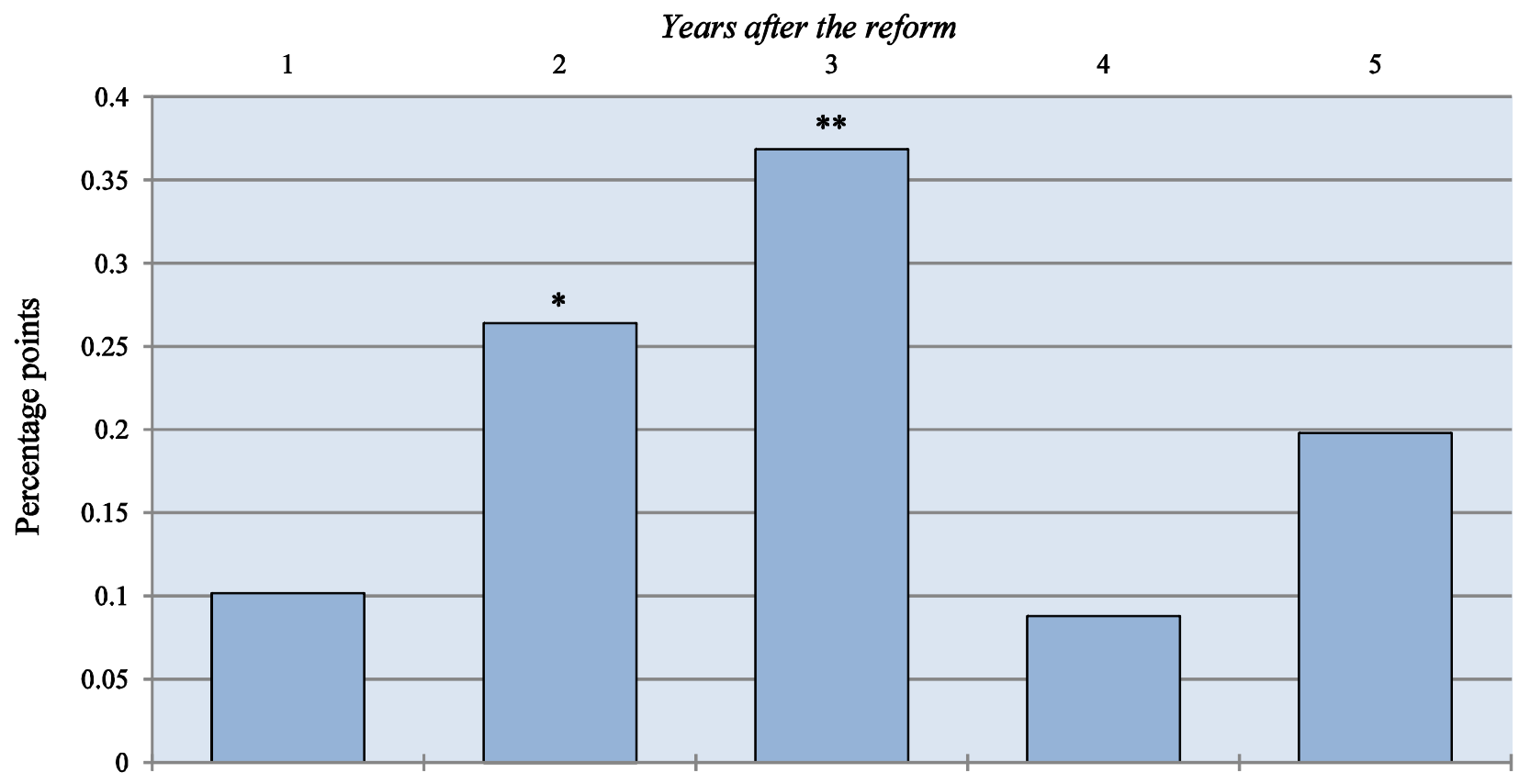

Note: ${ }^{* *}$ and * represent statistical significance at the 5 and $10 \%$ levels, respectively. The simulation is based on the median-sized reform observed in the estimation sample.

- On the other hand, the regression analysis delivers relatively weak results with respect to the impact of labour tax wedge cuts, despite these having been found to strongly and significantly influence long-term employment outcomes in the literature, including previous OECD work (Bassanini and Duval, 2006). Reductions in the labour tax wedge are associated with higher senior employment in the short run, driven by increased participation, but no effect on aggregate employment or unemployment can be detected, perhaps suggesting that the overall effect takes a long time to materialise.

\subsection{Product market reforms}

42. Product market reforms ${ }^{39}$ are found to boost participation in the medium term (Figure 9), especially for women. These reforms are also associated with short-term increases in consumption growth. However, they are also found to reduce investment and GDP growth, at odds with other recent OECD empirical analysis (Kerdrain et al., 2011). This might reflect capital spending cuts by incumbent firms in the wake of the privatisations that have accompanied a number of past reforms in this area.

39. The analysis relies on product market regulation (PMR) reforms in network industries (telecoms, electricity, gas, post, rail, air passenger transport, and road freight). Indeed, the unavailability of time series data on the "overall” PMR indicator makes it impossible to analyse the dynamic impact of economy-wide reforms. 
Figure 9. Change in aggregate labour force following an easing of product market regulation

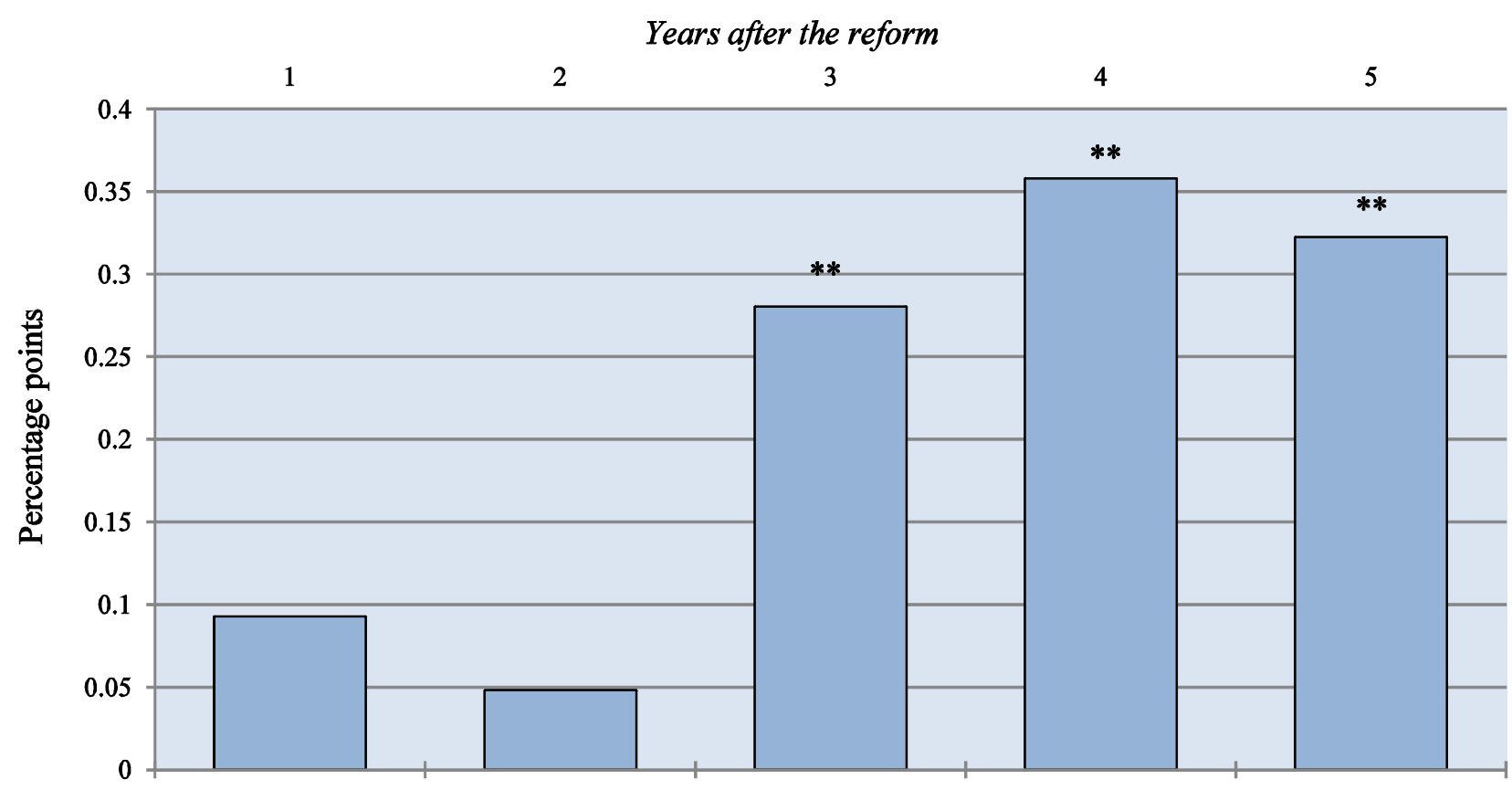

** represents statistical significance at the $5 \%$ level. The simulation is based on the median-sized reform observed in the estimation sample.

\subsection{Interactions between structural reforms and macroeconomic conditions and policies}

43. The previous section assessed the average short-term impact of reforms across past experiences. This impact may, however, vary depending not only on the overall institutional environment - an issue touched upon above - but also on macroeconomic conditions. If structural reforms raise supply more than demand in the short term, their immediate effects may be weaker in bad times, when output is already below potential, because it would take longer for demand to adjust to higher supply when the starting point is low. Another related issue is whether, and if so to what extent, macroeconomic policies should respond to (current or expected) reforms, e.g. to crowd in their otherwise possibly negative short-term effect. For instance, accommodating monetary or fiscal policies may accompany reforms which, under certain conditions - e.g. in bad times - and in the absence of macroeconomic response, would initially depress output.

\subsubsection{The influence of overall economic conditions}

44. The empirical analysis suggests that the short-term impact of structural reforms varies depending on the business cycle position, especially as regards unemployment benefit and job protection reforms. Evaluating the size of these interactions requires calculating marginal effects of reforms for different levels of economic activity (and their corresponding standard errors). Table 3 reports synthetic results on the employment impact of structural reforms calculated at the minimum, median and maximum values of the unemployment gap. While the baseline analysis suggests that on average positive effects of these reforms materialise quite rapidly, interacting reform shock variables with the unemployment gap suggests that short-term gains are stronger during "good" times, and weaker - and in some cases even negative - during "bad" times. 
45. The estimates imply that a median reduction in the initial unemployment benefit replacement rate would bring about a 0.5 percentage point employment gain after three years when the unemployment gap is at its median value of close to zero, but the same reform does not have any statistically significant effect for lower values of the initial unemployment gap and even brings significant employment losses in very depressed labour markets (Figure 10). ${ }^{40}$ This asymmetric effect may reflect the fact that while raising incentives for the unemployed to intensify job search and accept existing offers might be effective at increasing outflows from unemployment when the labour market is tight, it could be ineffective when labour demand is particularly weak, in which case negative effects may dominate.

Figure 10. Change in aggregate employment following a reduction in the initial unemployment benefit replacement rate: the influence of economic conditions

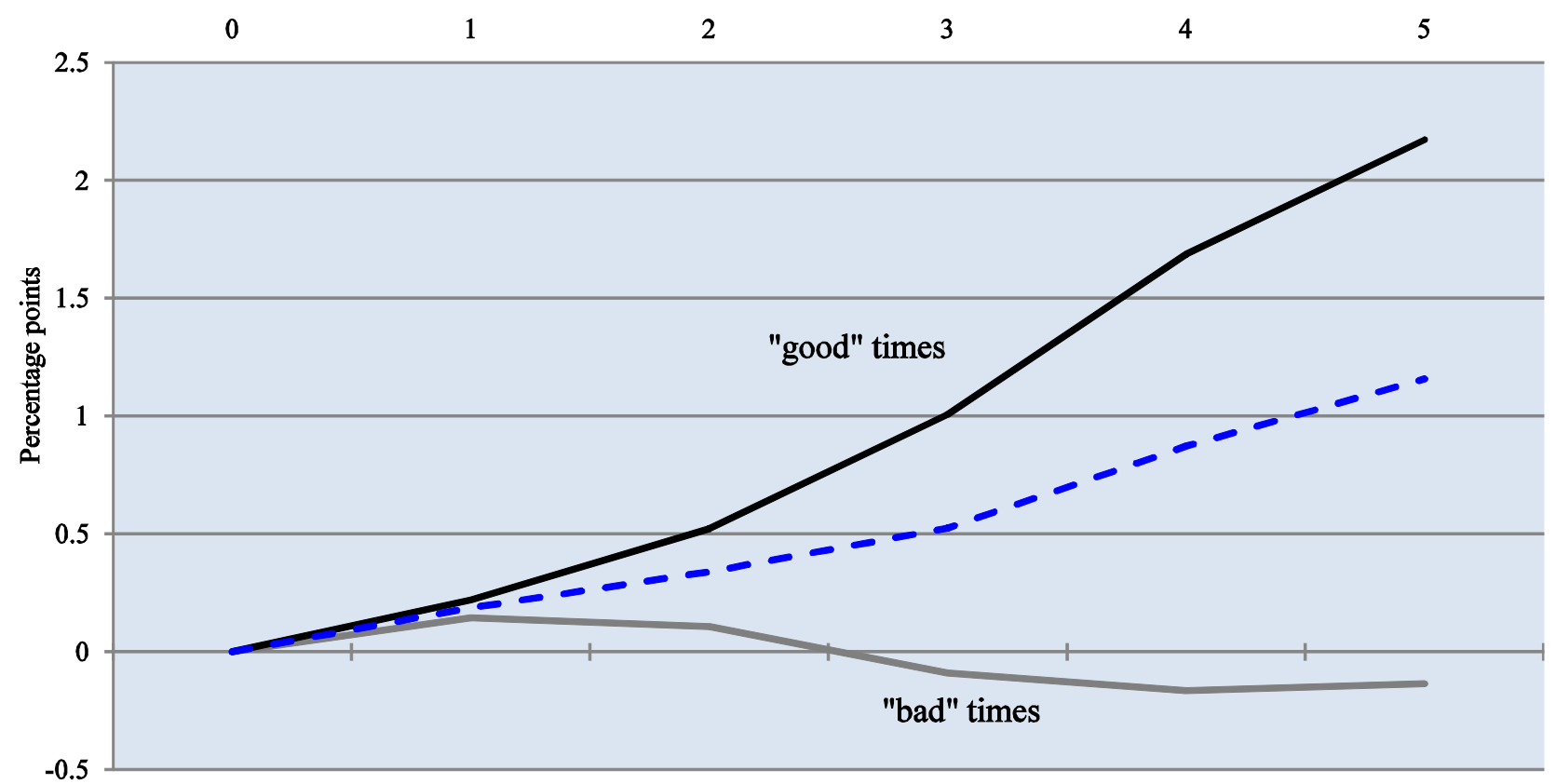

Note: The lower line corresponds to the impact of the reform during "bad" times, while the upper line represents the impact during "good" times, corresponding to the minimum and maximum levels of the unemployment gap, respectively, as observed across the sample (i.e. across all countries and time). The central broken line represents the impact of the reform when the unemployment gap equals its median value. The pre-reform unemployment gap is calculated as the difference between the NAIRU and the observed level of unemployment in the estimation sample.

40. The impact of the reform is found to be statistically insignificant for values of the unemployment gap lower than -1.4 and significantly negative for values of the unemployment gap lower than -5.2 (the minimum level of the unemployment gap is equal to -6.8 in the sample). 
Table 3. Short-term employment effects of structural reforms: the influence of economic conditions

\begin{tabular}{|c|c|c|c|c|c|c|c|c|c|c|c|c|}
\hline & & 1 & 2 & 3 & 4 & 5 & 6 & 7 & 8 & 9 & 10 & 11 \\
\hline & & $\begin{array}{l}\text { Decline in } \\
\text { initial UB } \\
\text { Replacement } \\
\text { Rate }\end{array}$ & $\begin{array}{l}\text { Decline in } \\
5 \text {-year } \\
\text { Average UB } \\
\text { Replacement } \\
\text { Rate }\end{array}$ & $\begin{array}{l}\text { Decline in } \\
\text { "UB } \\
\text { Duration" }\end{array}$ & 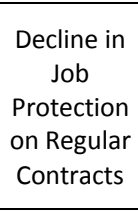 & $\begin{array}{l}\text { Decline in } \\
\text { Job } \\
\text { Protection } \\
\text { on } \\
\text { Temporary } \\
\text { Contracts } \\
\end{array}$ & $\begin{array}{c}\text { Decline in } \\
\text { Labour } \\
\text { Tax } \\
\text { Wedge }\end{array}$ & $\begin{array}{c}\text { Decline in } \\
\text { the Share } \\
\text { of Income } \\
\text { Tax in Total } \\
\text { Tax } \\
\text { Revenues }\end{array}$ & $\begin{array}{l}\text { Increase in } \\
\text { Spending } \\
\text { on ALMP in } \\
\text { Training }\end{array}$ & $\begin{array}{l}\text { Increase in } \\
\text { Spending on } \\
\text { ALMP in } \\
\text { Employment } \\
\text { Incentives }\end{array}$ & $\begin{array}{l}\text { Reduction of } \\
\text { "excess" } \\
\text { coverage of } \\
\text { collective } \\
\text { bargaining }\end{array}$ & $\begin{array}{l}\text { Decline in } \\
\text { Product } \\
\text { Market } \\
\text { Regulation }\end{array}$ \\
\hline \multirow{3}{*}{$\begin{array}{l}\text { Aggregate } \\
\text { employment }\end{array}$} & Unemployment gap Min & -- & $+\&-$ & - & - & NS & + & NS & NS & NS & ++ & NS \\
\hline & Unemployment gap Median & ++ & ++ & ++ & ++ & NS & NS & NS & + & ++ & +++ & NS \\
\hline & Unemployment gap Max & ++ & ++ & + & $+\&-$ & NS & + & NS & NS & ++ & + & NS \\
\hline \multirow{3}{*}{$\begin{array}{l}\text { Youth } \\
\text { employment }\end{array}$} & Unemployment gap Min & -- & $+\&-$ & -- & -- & + & $+\&-$ & -- & + & ++ & + & NS \\
\hline & Unemployment gap Median & + & + & ++ & ++ & - & + & ++ & + & + & +++ & - \\
\hline & Unemployment gap Max & ++ & ++ & ++ & $+\&-$ & -- & NS & ++ & $+\&-$ & -- & + & NS \\
\hline \multirow{3}{*}{$\begin{array}{l}\text { Women } \\
\text { employment }\end{array}$} & Unemployment gap Min & -- & $+\&-$ & ++ & --- & ++ & NS & NS & NS & NS & + & NS \\
\hline & Unemployment gap Med & ++ & ++ & + & +++ & NS & NS & NS & +++ & + & ++ & ++ \\
\hline & Unemployment gap Max & ++ & ++ & ++ & $+\&-$ & - & NS & NS & + & ++ & NS & NS \\
\hline \multirow{3}{*}{$\begin{array}{l}\text { Senior } \\
\text { employment }\end{array}$} & Unemployment gap Min & -- & $+\&-$ & -- & NS & + & + & - & NS & NS & ++ & - \\
\hline & Unemployment gap Med & ++ & ++ & ++ & NS & NS & + & NS & +++ & NS & ++ & NS \\
\hline & Unemployment gap Max & ++ & ++ & + & NS & NS & + & NS & NS & ++ & + & NS \\
\hline
\end{tabular}

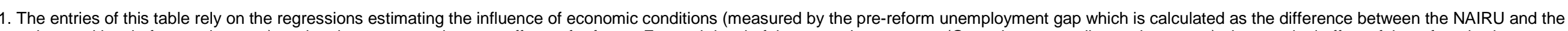

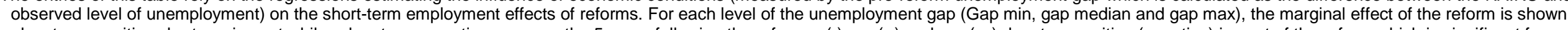

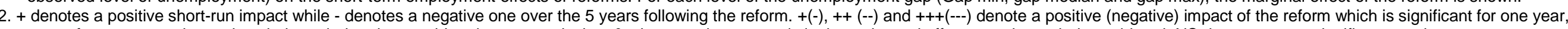
two to four years, and over the whole period under consideration, respectively. $+\&$ - denotes sign reversals in the estimated effect over the period considered. NS denotes a non-significant result. 
46. Likewise, a median decline in employment protection legislation would seem to deliver employment gains in the medium term when the unemployment gap is close to zero - although the magnitude of this interaction looks implausibly large - but to bring employment losses if the same reform is implemented when the unemployment rate is substantially above its structural level. A candidate explanation for this tentative result is that easing job protection mainly stimulates labour market demand and that the associated employment effect depends on the business cycle position. In "good" times, such reform may stimulate hiring by relaxing the hiring irreversibility perceived by employers, but in "bad" times, it may primarily increase inflows into unemployment by making it easier to fire workers.

\subsubsection{The role of institutional settings}

47. The regression analysis delivers some empirical evidence on interactions between structural reforms and institutional settings. These findings should be taken with caution given the difficulty to identify robust interactions between institutions in general, even when focusing only on long-run outcomes (for an extensive discussion focused on labour market outcomes, see Bassanini and Duval, 2009). Main significant results are presented in Table 4. More specifically:

- A reduction in unemployment income support (considering a summary measure of unemployment benefits throughout the unemployment spell) is associated with lower rather than higher employment (and with higher rather than lower unemployment) in the short run under tighter job protection. This suggests that strong job protection might prevent labour demand from responding fully to an increase in effective labour supply and lower reservation wages.

- By contrast, a relaxation of PMR is found to reduce employment and increase unemployment under weak job protection.

Table 4. Short-term employment effects of structural reforms: the influence of job protection

\begin{tabular}{|c|c|c|c|c|}
\hline & & \multicolumn{3}{|c|}{ Reform shocks } \\
\hline & & $\begin{array}{c}\text { Decline in initial } \\
\text { UB } \\
\text { Replacement } \\
\text { Rate }\end{array}$ & $\begin{array}{c}\text { Decline in } \\
\text { 5-year Average } \\
\text { UB } \\
\text { Replacement } \\
\text { Rate }\end{array}$ & $\begin{array}{l}\text { Decline in } \\
\text { product market } \\
\text { regulation }\end{array}$ \\
\hline \multirow{3}{*}{$\begin{array}{l}\text { Aggregate } \\
\text { employment }\end{array}$} & Job protection Min & + & ++ & -- \\
\hline & Job protection Median & NS & - & NS \\
\hline & Job protection Max & NS & - & +++ \\
\hline \multirow{3}{*}{$\begin{array}{l}\text { Youth } \\
\text { employment }\end{array}$} & Job protection Min & NS & ++ & NS \\
\hline & Job protection Median & + & - & NS \\
\hline & Job protection Max & NS & -- & + \\
\hline \multirow{3}{*}{$\begin{array}{l}\text { Women } \\
\text { employment }\end{array}$} & Job protection Min & NS & + & -- \\
\hline & Job protection Median & +++ & - & ++ \\
\hline & Job protection Max & ++ & - & +++ \\
\hline \multirow{3}{*}{$\begin{array}{l}\text { Senior } \\
\text { employment }\end{array}$} & Job protection Min & NS & + & - \\
\hline & Job protection Median & ++ & -- & NS \\
\hline & Job protection Max & + & -- & NS \\
\hline
\end{tabular}

1. The entries of this table rely on the regressions estimating the influence of institutional settings (measured by the level of the indicator of the institution in t-1) on the short-term effects of reforms. For each level of Job protection, the marginal effect of the reform is shown.

2. + denotes a positive short-run impact while - denotes a negative one over the 5 years following the reform. +(), ++ (--) and +++(---) denote a positive (negative) impact which is significant for one year, for two to four years, and over the whole period under consideration, respectively. $+\&$ - denotes sign reversals in the estimated effect over the period considered. NS denotes a non-significant result. 


\subsubsection{The role of macroeconomic policy settings}

48. The empirical analysis of interactions between structural reforms and macroeconomic policy settings does not deliver any compelling results. The baseline results reported above are robust to controlling for macroeconomic conditions prior to the reform in the baseline regressions, as measured by the nature of the exchange rate regime and the sustainability of the public finances. ${ }^{41,}{ }^{42}$ Controlling for coincident changes in macroeconomic policy settings does not affect the baseline results either, which tentatively suggests that the baseline analysis captures the direct effect of structural reforms, as opposed to any indirect impact that may be channelled through macroeconomic policy, in particular changes in the fiscal stance. ${ }^{43}$ No interactions between reform shocks and macroeconomic policy settings are found to be statistically significant. This finding may not come as much as a surprise given that:

- Macroeconomic policy primarily responds to large fluctuations in macroeconomic indicators (prices, output and employment). The macroeconomic effects of most past structural reforms may have been small compared with the impact of various macroeconomic shocks and business cycle fluctuations.

- The baseline results point to positive short-run effects of structural reforms. Insofar as this implies that reforms do not create economic slack in general - an hypothesis that could not be formally tested for here - there may be little need for expansionary macroeconomic policy to accompany

\subsection{Robustness analysis}

49. This section investigates the sensitivity of the baseline results to the following robustness checks: i) the use of alternative thresholds beyond which the change in a policy indicator is identified as a reform shock; ${ }^{44}$ ii) the introduction of "reverse" reforms as control variables in the baseline, measured as large changes in each of the policy indicators in the opposite direction; ${ }^{45}$ iii) the use of an alternative panel approach where the dependent variable is the annual variation of the variable of interest and the coefficients of the five lags of the reform shock are introduced simultaneously in a single equation; iv) the exclusion of the country fixed effects. Results presented below broadly confirm the robustness of the baseline estimates. It is also worth noting that when reforms are interdependent or implemented over the same period, estimating the effects of each reform in separate regressions may lead to an omitted-variable bias. However, the correlation between the reforms shocks is generally low, suggesting that such bias may be small in practice (see Table A4).

41. This incidentally indicates that potential selection bias stemming from the possible positive link between the room for fiscal policy manoeuvre and the probability of undertaking reform may not be a serious concern in practice.

42. Job protection reform stands out as an exception, as it is in this setting found to increase - rather than have no effect on - employment in the short run.

43. If the baseline regressions captured primarily indirect effects stemming from the macroeconomic policy responses to reforms, controlling for the latter should have severely weakened the size and significance of the estimated coefficients of the policy shock variables. No control is made for changes in macroeconomic policy settings in the baseline regressions themselves because of the major associated endogeneity issue (see Box 2).

44. These robustness checks are not applied to the estimates of the impact of changes in the retirement age and implicit taxes as reform shocks in these areas are identified by looking at the change in the corresponding policy indicator over several years in order to capture their typically longer phasing-in period.

45. The associated variable is equal to this large change when it is observed and zero otherwise. 


\subsubsection{Alternative thresholds for the definition of reform shocks}

50. In the baseline approach, a reform shock in a given policy area is identified when the corresponding indicator varies by more than two standard deviations of the annual variation calculated over all available observations. This section tests for the robustness of the baseline results when reducing or increasing the occurrence of reform shocks, i.e. by raising the stringency criterion used to identify them to 2.5 standard deviations or reducing it to 1.5 standard deviations. This comes across as considering "smaller" and "larger" reforms than in the baseline, respectively. Results are reported in Tables 5 and 6, with differences relative to the baseline highlighted in shaded cells. Estimates obtained with a lower number of reform shocks (shocks identified with a threshold of 2.5 standard deviations) are qualitatively similar to those obtained in the baseline (Table 5): only 16\% of the 237 results differ from the baseline, half of which because of a loss in statistical significance; and the other half due to a gain. More specifically:

- As in the baseline approach, a reduction in unemployment benefit replacement rates increases participation and employment as well as GDP and investment growth rates. Such reform is now also found to increase the consumption growth rate, contrary to what was found in the baseline. This result may be surprising given the immediate negative income effect of a cut in unemployment benefits. It is, however, consistent with the finding of increased labour utilisation and hence aggregate income. The negative effects of reforms on seniors and female employment are robust to the increase in the number of reform shocks.

- Results on job protection reforms appear to be fairly robust: reducing job protection on regular contracts is found to reduce unemployment especially for women and youths, while a decline in job protection for temporary contracts reduces youth and senior employment.

- Tax reforms do no longer appear to have a significant impact on labour market and macroeconomic performance: improvements in the tax structure - previously found to reduce aggregate unemployment and to increase youth participation - are now found to be statistically insignificant.

- In contrast, increases in ALMP spending on training appear in this setting to boost aggregate employment, female participation and private investment growth, on top of the beneficial effects identified in the baseline for aggregate unemployment and group-specific employment.

- Along the same lines, reductions of "excess" coverage of collective bargaining are now found to increase aggregate, youth and female employment rates, while these effects were not statistically significant in the baseline.

- Also in this setting, product market reforms are found to have insignificant effects except on aggregate participation, with the latter result being driven by positive effects on prime-age male participation. 
Table 5. Short-term impact of reforms: robustness to the use of a more stringent criterion for the identification of reform shocks (threshold of 2.5 standard deviations)

\begin{tabular}{|c|c|c|c|c|c|c|c|c|c|c|c|}
\hline & 1 & 2 & & 3 & 4 & 5 & 6 & 7 & 8 & 9 & 10 \\
\hline & $\begin{array}{c}\text { Decline in } \\
\text { 5-year Average } \\
\text { UB } \\
\text { Replacement }\end{array}$ & $\begin{array}{r}\text { Decline in } \\
\text { Replacement } \\
\text { in "UB D }\end{array}$ & $\begin{array}{l}\text { itial UB } \\
\text { te + Decline } \\
\text { ation" }\end{array}$ & $\begin{array}{l}\text { Decline in } \\
\text { Job } \\
\text { Protection } \\
\text { on Regular }\end{array}$ & $\begin{array}{l}\text { Decline in } \\
\text { Job } \\
\text { Protection } \\
\text { on }\end{array}$ & $\begin{array}{l}\text { Decline } \\
\text { in } \\
\text { Labour } \\
\text { Tax }\end{array}$ & $\begin{array}{l}\text { Decline in } \\
\text { the Share of } \\
\text { Income Tax } \\
\text { in Total Tax }\end{array}$ & $\begin{array}{l}\text { Increase in } \\
\text { Spending on } \\
\text { ALMP in } \\
\text { Training }\end{array}$ & $\begin{array}{l}\text { Increase in } \\
\text { Spending on } \\
\text { ALMP in } \\
\text { Employment }\end{array}$ & $\begin{array}{l}\text { Reduction of } \\
\text { "excess" coverage } \\
\text { of collective }\end{array}$ & $\begin{array}{l}\text { Decline in } \\
\text { Product } \\
\text { Market }\end{array}$ \\
\hline & & $\begin{array}{c}\text { Decline in } \\
\text { initial UB } \\
\text { Replacement } \\
\text { Rate } \\
\end{array}$ & $\begin{array}{l}\text { Decline in } \\
\text { "UB } \\
\text { Duration" }\end{array}$ & & & & & & & & \\
\hline Aggregate employment & ++ & ++ & -+ & NS & - & NS & NS & ++ & ++ & ++ & NS \\
\hline Youth & NS & + & + & NS & - & NS & NS & NS & + & ++ & NS \\
\hline Women & + & +++ & + & NS & NS & NS & NS & ++ & ++ & ++ & NS \\
\hline Senior & NS & + & - & NS & - & + & NS & ++ & ++ & ++ & NS \\
\hline Aggregate unemployment & -+ & NS & - & -- & NS & NS & NS & - & NS & -- & NS \\
\hline Youth & -- & NS & -- & -- & NS & NS & - & - & NS & -- & NS \\
\hline Women & + & + & NS & --- & NS & NS & NS & - & -- & -- & NS \\
\hline Senior & ++ & -- & NS & NS & NS & NS & NS & NS & NS & - & - \\
\hline Aggregate participation & + & ++ & + & NS & -- & NS & NS & NS & ++ & ++ & ++ \\
\hline Youth & NS & NS & + & NS & + & NS & NS & NS & NS & + & NS \\
\hline Women & ++ & ++ & NS & NS & - & NS & ++ & + & NS & NS & NS \\
\hline Senior & NS & NS & NS & NS & NS & + & NS & ++ & + & ++ & NS \\
\hline GDP growth rate & ++ & ++ & ++ & NS & -- & NS & NS & NS & NS & ++ & NS \\
\hline Consumption growth rate & + & + & ++ & NS & -- & -- & NS & -- & NS & + & NS \\
\hline Private investment growth rate & + & + & + & ++ & NS & - & ++ & + & NS & NS & NS \\
\hline
\end{tabular}

Note: The entries of this table rely on the regressions in which a 2.5 standard deviations threshold is used to identify a reform shock. + denotes a positive short-run impact while - denotes a negative one over the 5 years following the reform. +(-),++(--) and +++(---) denote a positive (negative) impact of the reform which is significant for one year, for two to four years, and over the whole period under consideration, respectively. $+\&$ - denotes sign reversals in the estimated effect over the period considered. NS denotes non-significant results. Shaded cells refer to results that differ from those obtained in the baseline regressions. 
51. Increasing rather than reducing the number of reform shocks (threshold of 1.5 standard deviations) produces results that differ from those of the baseline in more than $25 \%$ of the cases (Table 6), mainly because of a loss in statistical significance. This may not come as a surprise given that relaxing the stringency criterion implies considering relatively minor reforms whose effects are harder to identify, thus implying less significant coefficients over a short horizon. Alleviating this problem is in fact a key motivation for the baseline estimation strategy which focuses on major reform shocks. In particular:

- Some (but not all) of the effects of reforms in the areas of unemployment benefit duration, job protection on temporary contracts, tax structure, ALMPs spending (especially concerning training) and product markets are no longer significant.

- In such a setting, however, a few reforms which did not appear to have any effects in the baseline are now found to bring some significant short-term effects. In particular, a decline in unemployment benefit replacement rates is found to deliver an even greater number of significant employment effects than in the baseline.

\subsubsection{Introducing "reverse" reforms}

52. Results presented in the baseline approach are based on regressions ignoring "reverse" reforms, which can be defined as large changes in the policy indicators in the opposite direction. If these policy changes/"reverse" reforms dampen labour market performance and macroeconomic activity, omitting them from the regressions may lead to an overestimation of the positive effects of reforms. However, this does not seem to be the case in practice since associated regression results are generally consistent with the baseline findings (see Table 7) ${ }^{46}$ Only a few of the previously identified effects become non-significant, among which the impact on senior employment of unemployment benefit and labour tax wedge reforms, the impact of tax structure reforms on aggregate and youth unemployment and the unemployment impact of increased ALMP spending on training. In contrast, a decline in job protection on regular contracts is now associated with higher consumption growth in this setting, unlike in the baseline analysis. This last result would seem consistent with the idea (and the evidence in this paper) that such reforms primarily benefit "marginal” workers, who in turn may display a higher propensity to consume out of income.

\subsubsection{Estimations without country fixed effects}

53. Country fixed effects are aimed at controlling for unobserved cross-country heterogeneity in the change in the dependent variables. This is equivalent to saying that they control for country-specific trends in the level of the dependent variables (GDP growth, employment rate...etc), e.g. for the trend rise in participation in female employment rate equations. Yet, this empirical model might be incorrect if unobserved heterogeneity between countries applies to the level of, rather than the change in the independent variable, in which case a model without fixed effects would better capture the underlying dynamics. This is unlikely to be the case here since the country fixed effects are overall statistically significant in the baseline regressions, but still, as a robustness test, regressions are run without country fixed effects. Results reported in Table 8 are qualitatively similar to those obtained with country fixed effects, ${ }^{47}$ and even reinforce some findings regarding unemployment benefits, regular job protection, and tax structure reforms.

46. Instead of disentangling the effects of positive and negative reform shocks by including a new variable for reverse shocks, an alternative strategy would be to specify a new reform shock variable including simultaneously positive and negative shocks. Results from such approach are also consistent with baseline estimates, but they are generally less robust than those obtained when allowing the coefficient to differ between opposite-signed reforms. This does not come as a surprise as it may suggest that the effects of policy changes are not symmetrical.

47. Approximately one third of results differs from the baseline, half of which because of a loss in statistical significance and the other half due to a gain. 
Table 6. Short-term impact of reforms: Robustness to the use of a less stringent criterion for the identification of shocks

\begin{tabular}{|c|c|c|c|c|c|c|c|c|c|c|c|}
\hline & 1 & \multicolumn{2}{|c|}{2} & \multicolumn{6}{|c|}{5} & 9 & 10 \\
\hline & \multirow[t]{2}{*}{$\begin{array}{c}\text { Decline in } \\
\text { 5-year Average } \\
\text { UB } \\
\text { Replacement } \\
\text { Rate }\end{array}$} & \multicolumn{2}{|c|}{$\begin{array}{l}\text { Decline in initial UB } \\
\text { Replacement Rate + Decline } \\
\text { in "UB Duration" }\end{array}$} & \multirow[t]{2}{*}{$\begin{array}{c}\text { Decline in Job } \\
\text { Protection on } \\
\text { Regular } \\
\text { Contracts }\end{array}$} & \multirow{2}{*}{$\begin{array}{l}\text { Decline in } \\
\text { Job } \\
\text { Protection } \\
\text { on } \\
\text { Temporary } \\
\text { Contracts } \\
\end{array}$} & \multirow[t]{2}{*}{$\begin{array}{c}\text { Decline } \\
\text { in Labour } \\
\text { Tax } \\
\text { Wedge }\end{array}$} & \multirow[t]{2}{*}{$\begin{array}{l}\text { Decline in the } \\
\text { Share of } \\
\text { Income Tax in } \\
\text { Total Tax } \\
\text { Revenues }\end{array}$} & \multirow[t]{2}{*}{$\begin{array}{l}\text { Increase in } \\
\text { Spending } \\
\text { on ALMP in } \\
\text { Training }\end{array}$} & \multirow[t]{2}{*}{$\begin{array}{l}\text { Increase in } \\
\text { Spending on } \\
\text { ALMP in } \\
\text { Employment } \\
\text { Incentives }\end{array}$} & \multirow[t]{2}{*}{$\begin{array}{l}\text { Reduction of } \\
\text { "excess" coverage } \\
\text { of collective } \\
\text { bargaining }\end{array}$} & \multirow[t]{2}{*}{$\begin{array}{c}\text { Decline in } \\
\text { Product } \\
\text { Market } \\
\text { Regulation }\end{array}$} \\
\hline & & $\begin{array}{c}\text { Decline in } \\
\text { initial UB } \\
\text { Replacement } \\
\text { Rate }\end{array}$ & $\begin{array}{l}\text { Decline in } \\
\text { "UB } \\
\text { Duration" }\end{array}$ & & & & & & & & \\
\hline $\begin{array}{l}\text { Aggregate } \\
\text { employment }\end{array}$ & ++ & ++ & + & NS & - & NS & NS & NS & ++ & NS & NS \\
\hline Youth & + & -+ & + & NS & -- & NS & NS & NS & + & NS & NS \\
\hline Women & ++ & +++ & NS & NS & NS & ++ & NS & + & ++ & NS & NS \\
\hline Senior & + & + & -- & NS & NS & + & NS & ++ & ++ & ++ & NS \\
\hline $\begin{array}{l}\text { Aggregate } \\
\text { unemployment }\end{array}$ & - & -- & NS & -- & NS & NS & NS & NS & -- & -- & NS \\
\hline Youth & -- & - & NS & - & NS & NS & NS & NS & NS & -- & NS \\
\hline Women & NS & NS & NS & --- & NS & NS & NS & NS & -- & -- & NS \\
\hline Senior & NS & -- & NS & - & NS & NS & NS & NS & NS & -- & - \\
\hline $\begin{array}{l}\text { Aggregate } \\
\text { participation }\end{array}$ & + & ++ & + & - & NS & + & NS & NS & ++ & NS & NS \\
\hline Youth & NS & + & + & NS & -- & NS & NS & NS & NS & + & NS \\
\hline Women & ++ & +++ & NS & NS & NS & ++ & NS & NS & NS & NS & NS \\
\hline Senior & NS & NS & - & - & NS & NS & NS & ++ & + & ++ & NS \\
\hline GDP growth rate & ++ & ++ & + & + & -- & NS & NS & NS & - & ++ & - \\
\hline $\begin{array}{l}\text { Consumption } \\
\text { growth rate }\end{array}$ & ++ & + & ++ & NS & -- & - & NS & -- & NS & + & + \\
\hline $\begin{array}{l}\text { Private investment } \\
\text { growth rate }\end{array}$ & ++ & + & + & ++ & NS & NS & + & NS & NS & NS & +- \\
\hline
\end{tabular}

Note: The entries of this table rely on the regressions in which a 1.5 standard deviations threshold is used to identify a reform shock. + denotes a positive short-run impact while denotes a negative one over the 5 years following the reform. +(-),++ (--) and +++(---) denote a positive (negative) impact of the reform which is significant for one year, for two to four years, and over the whole period under consideration, respectively. $+\&$ - denotes sign reversals in the estimated effect over the period considered. NS denotes nonsignificant results. Shaded cells refer to results that differ from those obtained in the baseline analysis. 
Table 7. Short-term impact of structural reforms: robustness to controlling for "reverse" reform shocks

\begin{tabular}{|c|c|c|c|c|c|c|c|c|c|c|c|c|c|}
\hline & 1 & \multicolumn{2}{|c|}{2} & 3 & 4 & 5 & 6 & 7 & 8 & 9 & 10 & 11 & 12 \\
\hline & \multirow{2}{*}{$\begin{array}{l}\text { Decline in } \\
5 \text {-year } \\
\text { Average UB } \\
\text { Replacement } \\
\text { Rate }\end{array}$} & \multicolumn{2}{|c|}{$\begin{array}{l}\text { Decline in initial UB } \\
\text { Replacement Rate + Decline } \\
\text { in "UB Duration" }\end{array}$} & \multirow[t]{2}{*}{$\begin{array}{l}\text { Decline in Job } \\
\text { Protection on } \\
\text { Regular } \\
\text { Contracts }\end{array}$} & \multirow{2}{*}{$\begin{array}{c}\text { Decline in } \\
\text { Job } \\
\text { Protection } \\
\text { on } \\
\text { Temporary } \\
\text { Contracts } \\
\end{array}$} & \multirow[t]{2}{*}{$\begin{array}{c}\text { Decline in } \\
\text { Labour } \\
\text { Tax } \\
\text { Wedge }\end{array}$} & \multirow{2}{*}{$\begin{array}{c}\text { Decline in } \\
\text { the Share } \\
\text { of Income } \\
\text { Tax in } \\
\text { Total Tax } \\
\text { Revenues }\end{array}$} & \multirow{2}{*}{$\begin{array}{c}\text { Increase } \\
\text { in } \\
\text { Spending } \\
\text { on ALMP } \\
\text { in } \\
\text { Training } \\
\end{array}$} & \multirow[t]{2}{*}{$\begin{array}{l}\text { Increase in } \\
\text { Spending on } \\
\text { ALMP in } \\
\text { Employment } \\
\text { Incentives }\end{array}$} & \multirow[t]{2}{*}{$\begin{array}{l}\text { Reduction } \\
\text { of "excess" } \\
\text { coverage of } \\
\text { collective } \\
\text { bargaining }\end{array}$} & \multirow[t]{2}{*}{$\begin{array}{l}\text { Decline in } \\
\text { Product Market } \\
\text { Regulation }\end{array}$} & \multirow[t]{2}{*}{$\begin{array}{l}\text { Increase in } \\
\text { Minimum } \\
\text { Retirement } \\
\text { Age }\end{array}$} & \multirow[t]{2}{*}{$\begin{array}{l}\text { Decline in } \\
\text { Implicit Tax } \\
\text { on } \\
\text { Continued } \\
\text { Work }\end{array}$} \\
\hline & & $\begin{array}{c}\text { Decline in } \\
\text { initial UB } \\
\text { Replacement } \\
\text { Rate } \\
\end{array}$ & $\begin{array}{l}\text { Decline in } \\
\text { "UB } \\
\text { Duration" }\end{array}$ & & & & & & & & & & \\
\hline $\begin{array}{l}\text { Aggregate } \\
\text { employment }\end{array}$ & + & + & + & NS & -- & NS & NS & NS & ++ & NS & NS & & \\
\hline Youth & NS & + & + & NS & - & NS & NS & NS & NS & NS & NS & & \\
\hline Women & NS & ++ & ++ & NS & NS & NS & NS & + & ++ & NS & ++ & & \\
\hline Senior & NS & NS & NS & NS & NS & NS & NS & ++ & ++ & ++ & NS & --- & -- \\
\hline $\begin{array}{l}\text { Aggregate } \\
\text { unemployment }\end{array}$ & - & NS & - & -- & NS & NS & NS & NS & - & NS & NS & & \\
\hline Youth & -- & NS & -- & -- & NS & NS & NS & NS & NS & NS & NS & & \\
\hline Women & NS & + & - & -- & + & NS & NS & NS & -- & -- & - & & \\
\hline Senior & NS & -- & NS & NS & NS & + & NS & NS & NS & -- & NS & ++ & NS \\
\hline $\begin{array}{l}\text { Aggregate } \\
\text { participation }\end{array}$ & + & + & + & NS & -- & NS & NS & NS & ++ & ++ & ++ & & \\
\hline Youth & + & NS & + & NS & - & NS & NS & NS & NS & + & NS & & \\
\hline Women & + & ++ & NS & NS & - & NS & + & NS & NS & NS & ++ & & \\
\hline Senior & NS & NS & NS & NS & NS & + & NS & ++ & + & ++ & NS & --- & -- \\
\hline GDP growth rate & + & ++ & ++ & NS & -- & NS & NS & NS & NS & + & - & ++ & ++ \\
\hline $\begin{array}{l}\text { Consumption } \\
\text { growth rate }\end{array}$ & ++ & $+\&-$ & ++ & + & -- & - & NS & -- & NS & + & + & ++ & NS \\
\hline $\begin{array}{l}\text { Private investment } \\
\text { growth rate }\end{array}$ & + & ++ & + & ++ & - & NS & ++ & NS & NS & NS & - & $-1+$ & + \\
\hline
\end{tabular}

Note: The entries of this table rely on regressions controlling for "reverse" reform shocks along with baseline reform shocks + denotes a positive short-run impact while - denotes a negative one over the 5 years following the reform. +(-) ++ (--) and +++(---) denote a positive (negative) impact of the reform which is significant for one year, for two to four years, and over the whole period under consideration, respectively. $+\&$ - denotes sign reversals in the estimated effect over the period considered. NS denotes non-significant results. Shaded cells refer to results that differ from those obtained in the baseline analysis. 
Table 8. Short-term impact of structural reforms: robustness to the exclusion of country fixed effects

\begin{tabular}{|c|c|c|c|c|c|c|c|c|c|c|c|c|c|}
\hline & 1 & \multicolumn{2}{|c|}{2} & 3 & 4 & 5 & 6 & 7 & 8 & 9 & 10 & 11 & 12 \\
\hline & $\begin{array}{c}\text { Decline in 5- } \\
\text { year Average } \\
\text { UB } \\
\text { Replacement }\end{array}$ & \multicolumn{2}{|c|}{$\begin{array}{c}\text { Decline in initial UB } \\
\text { Replacement Rate + Decline } \\
\text { in "UB Duration" }\end{array}$} & $\begin{array}{l}\text { Decline in } \\
\text { Job } \\
\text { Protection } \\
\text { on Regular }\end{array}$ & $\begin{array}{l}\text { Decline in } \\
\text { Job } \\
\text { Protection } \\
\text { on }\end{array}$ & $\begin{array}{l}\text { Decline in } \\
\text { Labour Tax } \\
\text { Wedge }\end{array}$ & $\begin{array}{l}\text { Decline in } \\
\text { the Share of } \\
\text { Income Tax } \\
\text { in Total Tax }\end{array}$ & $\begin{array}{l}\text { Increase in } \\
\text { Spending } \\
\text { on ALMP in }\end{array}$ & $\begin{array}{l}\text { Increase in } \\
\text { Spending on } \\
\text { ALMP in } \\
\text { Employment }\end{array}$ & $\begin{array}{l}\text { Reduction } \\
\text { of "excess" } \\
\text { coverage of } \\
\text { collective }\end{array}$ & $\begin{array}{l}\text { Decline in } \\
\text { Product } \\
\text { Market }\end{array}$ & $\begin{array}{l}\text { Increase in } \\
\text { Minimum } \\
\text { Retirement }\end{array}$ & $\begin{array}{l}\text { Decline in } \\
\text { Implicit Tax } \\
\text { on } \\
\text { Continued }\end{array}$ \\
\hline & & $\begin{array}{c}\text { Decline in } \\
\text { initial UB } \\
\text { Replacement } \\
\text { Rate } \\
\end{array}$ & $\begin{array}{l}\text { Decline in } \\
\text { "UB } \\
\text { Duration" }\end{array}$ & & & & & & & & & & \\
\hline $\begin{array}{l}\text { Aggregate } \\
\text { employment }\end{array}$ & + & +++ & NS & +++ & - & NS & + & NS & ++ & NS & NS & & \\
\hline Youth & + & +++ & + & + & NS & NS & + & NS & NS & NS & NS & & \\
\hline Women & + & +++ & NS & +++ & NS & NS & +++ & NS & NS & NS & NS & & \\
\hline Senior & NS & ++ & -- & ++ & NS & ++ & NS & NS & NS & ++ & NS & --- & -- \\
\hline $\begin{array}{l}\text { Aggregate } \\
\text { unemployment }\end{array}$ & - & --- & - & --- & NS & NS & - & NS & NS & NS & NS & & \\
\hline Youth & -- & -- & -- & --- & NS & NS & -- & NS & NS & NS & NS & & \\
\hline Women & NS & NS & NS & --- & + & NS & NS & NS & NS & NS & NS & & \\
\hline Senior & NS & -- & NS & -- & NS & NS & NS & NS & NS & -- & NS & ++ & ++ \\
\hline $\begin{array}{l}\text { Aggregate } \\
\text { participation }\end{array}$ & + & ++ & - & + & NS & NS & ++ & - & NS & NS & NS & & \\
\hline Youth & + & ++ & + & NS & + & NS & NS & NS & NS & NS & NS & & \\
\hline Women & NS & ++ & NS & NS & NS & NS & ++ & NS & NS & NS & NS & & \\
\hline Senior & NS & + & - & NS & NS & ++ & NS & NS & NS & ++ & NS & --- & -- \\
\hline $\begin{array}{l}\text { GDP growth } \\
\text { rate }\end{array}$ & + & ++ & NS & + & -- & NS & NS & NS & - & + & NS & ++ & - \\
\hline $\begin{array}{l}\text { Consumption } \\
\text { growth rate }\end{array}$ & ++ & + & ++ & ++ & -- & NS & NS & -- & - & + & + & ++ & - \\
\hline $\begin{array}{l}\text { Private } \\
\text { investment } \\
\text { growth rate }\end{array}$ & ++ & + & + & + & - & NS & + & NS & NS & NS & - & -+ & ++ \\
\hline
\end{tabular}

Note: The entries of this table rely on regressions excluding the country fixed effects from the baseline specification. + denotes a positive short-run impact while - denotes a negative one over the 5 years following the reform. $+(-),++(--)$ and $+++(--)$ denote a positive (negative) impact of the reform which is significant for one year, for two to four years, and over the whole period under consideration, respectively. $+\&$ - denotes sign reversals in the estimated effect over the period considered. NS denotes non-significant results. Shaded cells refer to results that diffe from those obtained in the baseline analysis. 


\subsubsection{An alternative dynamic model}

54. Instead of estimating the effects of a given structural reform on the one- to five-year changes in the dependent variable, the short-term effects of reforms can also be assessed by investigating how the annual change in the dependent variable reacts to reforms that occurred one to five years before. Formally, the following equation is estimated:

$$
\Delta Y_{i, t+1}=\alpha+\sum_{j=0}^{j=5} \beta_{j} \Delta Y_{i, t-j}+\sum_{l=0}^{l=4} \phi_{l} \text { reform }_{i, t-l}+\sum_{j=0}^{j=5} \lambda_{h, j} \text { crisis }_{h, t-j}+\gamma_{i}+\gamma_{t}+\varepsilon_{i, t} \text {, }
$$

where the variables $Y$, reform and crisis $h_{h}$ are defined as in the baseline, and $\gamma_{i}$ and $\gamma_{t}$ are respectively country and time fixed effects. The coefficients of interest are the estimated $\varnothing_{l}$ (with $l=0 \ldots 4$ ). The results reported in Table 9 are broadly consistent with the baseline, although some of them tend to be less significant.

\subsubsection{Assessing the overall robustness of the results}

55. Table 10 provides an overall assessment of the robustness of the baseline results by reporting significant findings that are common to the baseline specification, the specification using a more stringent criterion to identify the reform shocks, and that controlling for "reverse" reform shocks. These specifications are chosen because they are the most closely related to the estimated model and because they can be considered as the most meaningful sensitivity checks. The following effects appear to be significant regardless of the specification:

- Declines in unemployment benefit replacement rates are found to have raised aggregate employment and participation, reduced youth unemployment and increased female participation and employment. Also, in all specifications, investment growth has increased following a decline in average and initial unemployment benefit replacement rates. Also, a decline in initial (average) replacement rates has resulted in a rise in the GDP and consumption growth rates.

- Declines in the duration of unemployment benefits appear to have stimulated participation and employment (notably for youths and women) and reduced unemployment.

- The decrease in aggregate and youth unemployment associated to a decline in job protection on regular contracts appears fairly robust to alternative specifications. The same holds true as regards the negative impact of a decline in job protection on temporary contracts on employment, participation and the growth rates of investment, consumption and GDP.

- Reductions in the labour tax wedge and reforms of the tax structure have had robust effects only on female and senior participation, consistent with the view that such groups are generally more responsive to changes in taxes. The investment-enhancing effect of a shift from direct to indirect taxes is also robust to the use of alternative specifications.

- A decline in "excess" coverage of collective bargaining is found to have raised senior employment as well as aggregate, youth and senior participation. It has also reduced female and senior unemployment.

- The same holds true as regards a rise in ALMP spending on training and employment incentives, which is found to have boosted participation and employment of women and seniors.

- Product market reforms are estimated to have robustly increased aggregate labour force participation. 
Table 9. Short-term impact of structural reforms: robustness to using an alternative dynamic model

\begin{tabular}{|c|c|c|c|c|c|c|c|c|c|c|c|c|c|}
\hline & 1 & \multicolumn{2}{|c|}{2} & 3 & 4 & 5 & 6 & 7 & 8 & 9 & 10 & 11 & 12 \\
\hline & \multirow[t]{2}{*}{$\begin{array}{l}\text { Decline in 5-year } \\
\text { Average UB } \\
\text { Replacement } \\
\text { Rate }\end{array}$} & \multicolumn{2}{|c|}{$\begin{array}{c}\text { Decline in initial UB } \\
\text { Replacement Rate + Decline in } \\
\text { "UB Duration" }\end{array}$} & \multirow[t]{2}{*}{$\begin{array}{c}\text { Decline in } \\
\text { Job } \\
\text { Protection } \\
\text { on Regular } \\
\text { Contracts }\end{array}$} & \multirow{2}{*}{$\begin{array}{l}\text { Decline in } \\
\text { Job } \\
\text { Protection } \\
\text { on } \\
\text { Temporary } \\
\text { Contracts }\end{array}$} & \multirow[t]{2}{*}{$\begin{array}{l}\text { Decline } \\
\text { in } \\
\text { Labour } \\
\text { Tax } \\
\text { Wedge }\end{array}$} & \multirow{2}{*}{$\begin{array}{l}\text { Decline } \\
\text { in the } \\
\text { Share of } \\
\text { Income } \\
\text { Tax in } \\
\text { Total Tax } \\
\text { Revenues }\end{array}$} & \multirow{2}{*}{$\begin{array}{l}\text { Increase } \\
\text { in } \\
\text { Spending } \\
\text { on ALMP } \\
\text { in } \\
\text { Training }\end{array}$} & \multirow[t]{2}{*}{$\begin{array}{l}\text { Increase in } \\
\text { Spending on } \\
\text { ALMP in } \\
\text { Employment } \\
\text { Incentives }\end{array}$} & \multirow[t]{2}{*}{$\begin{array}{l}\text { Reduction of } \\
\text { "excess" } \\
\text { coverage of } \\
\text { collective } \\
\text { bargaining }\end{array}$} & \multirow[t]{2}{*}{$\begin{array}{l}\text { Decline in } \\
\text { Product } \\
\text { Market } \\
\text { Regulation }\end{array}$} & \multirow[t]{2}{*}{$\begin{array}{l}\text { Increase in } \\
\text { Minimum } \\
\text { Retirement } \\
\text { Age }\end{array}$} & \multirow[t]{2}{*}{$\begin{array}{l}\text { Decline in } \\
\text { Implicit Tax } \\
\text { on } \\
\text { Continued } \\
\text { Work }\end{array}$} \\
\hline & & $\begin{array}{c}\text { Decline in } \\
\text { initial UB } \\
\text { Replacement } \\
\text { Rate } \\
\end{array}$ & $\begin{array}{l}\text { Decline in } \\
\text { "UB } \\
\text { Duration" }\end{array}$ & & & & & & & & & & \\
\hline Aggregate employment & + & ++ & + & ++ & NS & NS & NS & - & + & + & NS & & \\
\hline Youth & + & + & NS & + & - & - & NS & -- & - & NS & NS & & \\
\hline Women & ++ & + & ++ & + & NS & NS & NS & NS & + & + & NS & & \\
\hline Senior & + & + & - & $-\&+$ & NS & + & - & + & NS & ++ & NS & + & -- \\
\hline $\begin{array}{l}\text { Aggregate } \\
\text { unemployment }\end{array}$ & -- & NS & -- & -- & + & NS & - & NS & NS & - & NS & & \\
\hline Youth & -- & -- & -- & -- & + & + & - & NS & NS & -- & + & & \\
\hline Women & $-\&+$ & NS & -- & -- & $-\&+$ & NS & - & NS & - & - & NS & & \\
\hline Senior & - & - & -- & - & NS & NS & + & NS & NS & $-\&+$ & NS & --- & + \\
\hline Aggregate participation & NS & NS & NS & NS & - & NS & NS & - & - & NS & + & & \\
\hline Youth & NS & + & NS & NS & NS & NS & -- & NS & - & + & NS & & \\
\hline Women & + & ++ & NS & - & NS & + & + & + & NS & NS & + & & \\
\hline Senior & NS & + & - & $-\&+$ & NS & NS & NS & ++ & NS & + & - & NS & -- \\
\hline GDP growth rate & NS & ++ & ++ & + & - & - & + & NS & - & NS & - & - & NS \\
\hline $\begin{array}{l}\text { Consumption growth } \\
\text { rate }\end{array}$ & + & + & + & + & NS & NS & NS & - & + & $-\&+$ & NS & ++ & NS \\
\hline $\begin{array}{l}\text { Private investment } \\
\text { growth rate }\end{array}$ & + & + & ++ & ++ & - & $-\&+$ & NS & + & NS & NS & - & + & $-1+$ \\
\hline
\end{tabular}

Note: The entries of this table are based on an alternative dynamic model where the annual change in the dependant variable is regressed on contemporaneous and lagged reform shocks. No attempt has been made at directly comparing these results with the baseline (Table 1) by shading cells as the number of reported signs in Table 1 refers to the number of time the coefficient of reform shock is significant when running five regressions (see equation [1] in the text) whereas the number of reported signs in this table refers to the number of reform shock coefficients that are significant among the contemporaneous and lagged terms of the dynamic model (see equation [4] in the text). + denotes a positive short-run impact while - denotes a negative one. +(-),++ (--) and +++(---), indicate that one, two to four, and all five coefficients of reform shocks are significant, respectively. $+\&$ - denotes sign reversals in the estimated effect. NS denotes non-significant results. 
Table 10. Short-term impact of structural reforms: assessing the overall robustness of the results

\begin{tabular}{|c|c|c|c|c|c|c|c|c|c|c|c|}
\hline & 1 & 2 & & 3 & 4 & 5 & 6 & 7 & 8 & 9 & 10 \\
\hline & $\begin{array}{l}\text { Decline in 5-year } \\
\text { Average UB } \\
\text { Replacement } \\
\text { Rate }\end{array}$ & $\begin{array}{r}\text { Decline in } \\
\text { Replacement R } \\
\text { "UB Du }\end{array}$ & $\begin{array}{l}\text { itial UB } \\
\text { + Decline in } \\
\text { con" }\end{array}$ & $\begin{array}{c}\text { Decline in } \\
\text { Job } \\
\text { Protection } \\
\text { on Regular } \\
\text { Contracts }\end{array}$ & $\begin{array}{c}\text { Decline in Job } \\
\text { Protection on } \\
\text { Temporary } \\
\text { Contracts }\end{array}$ & $\begin{array}{c}\text { Decline in } \\
\text { Labour } \\
\text { Tax } \\
\text { Wedge }\end{array}$ & $\begin{array}{c}\text { Decline in the } \\
\text { Share of } \\
\text { Income Tax in } \\
\text { Total Tax } \\
\text { Revenues }\end{array}$ & $\begin{array}{l}\text { Increase in } \\
\text { Spending on } \\
\text { ALMP in Training }\end{array}$ & $\begin{array}{l}\text { Increase in } \\
\text { Spending on ALMP } \\
\text { in Employment } \\
\text { Incentives }\end{array}$ & $\begin{array}{l}\text { Reduction of } \\
\text { "excess" } \\
\text { coverage of } \\
\text { collective } \\
\text { bargaining }\end{array}$ & $\begin{array}{c}\text { Decline in } \\
\text { Product } \\
\text { Market } \\
\text { Regulation }\end{array}$ \\
\hline & & $\begin{array}{c}\text { Decline in } \\
\text { initial UB } \\
\text { Replacement } \\
\text { Rate } \\
\end{array}$ & $\begin{array}{l}\text { Decline in } \\
\text { "UB } \\
\text { Duration" }\end{array}$ & & & & & & & & \\
\hline $\begin{array}{l}\text { Aggregate } \\
\text { employment }\end{array}$ & + & ++ & & NS & -- & NS & NS & & ++ & & NS \\
\hline Youth & NS & & + & & - & NS & NS & NS & & & NS \\
\hline Women & & +++ & + & NS & NS & NS & NS & ++ & ++ & & \\
\hline Senior & NS & & & NS & & & NS & ++ & ++ & ++ & NS \\
\hline $\begin{array}{l}\text { Aggregate } \\
\text { unemployment }\end{array}$ & & NS & - & -- & NS & NS & & & & & NS \\
\hline Youth & -- & NS & -- & -- & NS & NS & & & NS & & NS \\
\hline Women & & + & & --- & & NS & NS & & -- & -- & \\
\hline Senior & & & NS & NS & NS & & NS & NS & NS & -- & \\
\hline $\begin{array}{l}\text { Aggregate } \\
\text { participation }\end{array}$ & + & ++ & + & NS & -- & NS & NS & NS & ++ & + & ++ \\
\hline Youth & & NS & + & NS & - & NS & & NS & NS & + & NS \\
\hline Women & + & ++ & NS & NS & - & NS & ++ & & NS & NS & \\
\hline Senior & & NS & NS & NS & NS & + & NS & ++ & + & ++ & NS \\
\hline GDP growth rate & & ++ & ++ & NS & -- & NS & NS & NS & NS & + & \\
\hline $\begin{array}{l}\text { Consumption } \\
\text { growth rate }\end{array}$ & + & & ++ & & -- & & NS & -- & NS & + & \\
\hline $\begin{array}{l}\text { Private investment } \\
\text { growth rate }\end{array}$ & + & + & + & ++ & - & & + & & NS & NS & \\
\hline
\end{tabular}

Note: The entries of this table report results that are common to the baseline specification, to the specification using more stringent criteria to identify reform shocks and to the specification controlling for "reverse" reform shocks. + denotes a positive short-run impact while - denotes a negative one over the 5 years following the reform. +(-), ++ (--) and $+++(--)$ denote a positive (negative) impact of the reform which is significant for one year, for two to four years, and over the whole period under consideration, respectively. $+++(--)$ denote a positive (negative) impact of the reform which is significant for one year, for two to four years, ar 


\section{Conclusion}

56. Drawing on empirical analysis of 30 years of structural reforms across the OECD, this paper has shed light on the dynamic impact of structural reforms, an issue which has been little researched so far. One important finding which fits theoretical priors is that the gains from reforms typically take time to fully materialise. A bit more surprisingly, no type of reform is found on average to involve significant aggregate economic losses, and indeed a number of them appear to deliver some benefits already in the short run. The absence of major depressing effects does not lend support to the view that reforms should be accompanied by substantial macroeconomic policy easing in order to deliver some short-term gains. Nevertheless, there is tentative evidence that some labour market reforms (of unemployment benefit systems and job protection) pay off more quickly in good times than in bad times, and can even entail short-term losses in severely depressed economies. 


\section{BIBLIOGRAPHY}

Abiad, A., E. Detragiache, and T. Tressel (2008), “A New Database of Financial Reforms”, IMF Working Paper, No. 266.

Acemoglu, D. and R. Shimer (2000), “Productivity Gains from Unemployment Insurance”, European Economic Review, Vol. 44, pp. 1195-1224.

Adjémian, S., C. Cahn, A. Devulder, and N. Maggiar (2007), “Variantes en Univers Incertain”, Économie et Prévision, Special Issue "Développements récents des DSGE”.

Aghion, P., R. Blundell, R. Griffith, P. Howitt, and S. Prantl (2004), "Entry and Productivity Growth: Evidence from Microlevel Panel Data." Journal of the European Economic Association, April-May, 2(2-3). pp. 265-276.

Aghion, P. and P. Howitt (1998), Endogenous Growth Theory, The MIT Press.

Ahrend, R., J. Arnold, and C. Moser (2011), “The Sharing of Macroeconomic Risk: Who Losses (and Gains) from Macroeconomic Shocks”, OECD Economics Department Working Papers, No. 877.

Alesina, A., S. Ardagna, G. Nicoletti, and F. Schiantarelli (2005), "Regulation and Investment,” Journal of the European Economic Association 3, 791-825.

Amable, B., L. Demmou, D. Gatti (2011), “The Effect of Employment Protection and Product Market Regulation on Labour Market Performance: Substitution or Complementarity?”, Applied Economics, 43: 4, pp. 449-464.

Andrews, D., A. Caldera-Sanchez, and A. Johansson (2011), "Housing Markets and Structural Policies in OECD countries,” OECD Economics Department Working Papers, No. 836, OECD Publishing.

Angeloni, I., A. Kashyap, B. Mojon, and D. Terlizzese (2003), "The Output Composition Puzzle: A Difference in the Monetary Transmission Mechanism in the Euro Area and United States”, Journal of Money, Credit, and Banking, Vol. 35, No. 6, pp. 1265-1306.

Arnold, J. (2008), "Do Tax Structures Affect Aggregate Economic Growth?: Empirical Evidence from a Panel of OECD Countries", OECD Economics Department Working Papers, No.643, OECD Publishing.

Arnold, J., B. S. Javorcik, M. Lipscomb, and A. Mattoo (2010), "Services Reform and Manufacturing Performance: Evidence from India”, CEPR Discussion Paper, No. 8011.

Arnold, J., Javorcik B. S., and A. Mattoo (2011), "Does Services Liberalisation Benefit Manufacturing Firms? Evidence from the Czech Republic”, Journal of International economics, forthcoming.

Arpaia, A., R. Werner, J. Varga, and J. in’t Veld (2007), “Quantitative Assessment of Structural Reforms: Modeling the Lisbon Strategy”, European Commission Economic Papers, No. 282.

Bayoumi, T. (2004), “GEM: a New International Macroeconomic Model”, IMF Occasional Paper No. 239.

Bassanini, A. and R. Duval (2006), "Employment Patterns in OECD Countries: Reassessing the Role of Policies and Institutions”, OECD Economics Department Working Papers, No. 486. 
Bassanini, A. and R. Duval, (2009), "Unemployment, Institutions, and Reform Complementarities: Reassessing the Aggregate Evidence for OECD Countries”, Oxford Review of Economic Policy 25, 40-59, Spring.

Bassanini, A., L. Nunziata, and D. Venn (2009), "Job Protection Legislation and Productivity Growth in OECD Countries”, Economic Policy, Vol. 24, No. 58, pp. 349-402, April.

Bayoumi, T., D. Laxton, and P. Pesenti (2004), "Benefits and Spillovers of Greater Competition in Europe: a Macroeconomic Assessment”, Board of Governors of the Federal Reserve System, International Finance Discussion paper, No. 803.

Bentolila, S., P. Cahuc, J.J. Dolado, and T. Le Barbanchon (2010), “Two-tier Labor Markets in the Great Recession: France vs. Spain,” IZA Discussion Paper series, No. 5340.

Bertrand, M. and F. Kramarz (2002), "Does Entry Regulation Hinder Job Creation? Evidence from the French Retail Industry,” Quarterly Journal of Economics 117, 1369-1413.

Black, D.A., J.A Smith, M.C. Berger, and J.N Brett (2003), "Is the Threat of Reemployment Services More Effective than the Services Themselves? Evidence from a Random Assignment in the UI System", American Economic Review, Vol. 93, pp. 1313-1327.

Blanchard, O. and F. Giavazzi (2003), "Macroeconomic Effects of Regulation and Deregulation in Goods and Labor Markets”, Quarterly Journal of Economics, August 2003, pp. 879-907.

Blanchard, O. and A. Landier (2002), "The Perverse Effects of Partial Labour Market Reform: Fixed-Term Contracts in France”, Economic Journal 112, pp. F214-F244, June.

Boeri (2010), "Institutional Reforms in European Labor Markets”, Università Bocconi e Fondazione Rodolfo Debenedetti, mimeo.

Boeri, T., and P. Garibaldi (2007), "Two-tier Reforms of Employment Protection: a Honeymoon Effect?”, The Economic Journal, 117 (June), F357-385.

Botmain, D., P. Karam, D. Laxton, and D. Rose (2007), 'DSGE Modeling at the Fund: Applications and Further Developments”, IMF Working Paper, No. 200.

Bourlès, R., G. Cette, J. Lopez, J. Mairesse, and G. Nicoletti (2010), "Do Product Market Regulations in Upstream Sectors Curb Productivity Growth?: Panel Data Evidence for OECD Countries”, OECD Economics Department Working Papers, No. 791.

Branstetter, L.G., F. Lima, L.J. Taylor, and A. Venacio (2010), "Do Entry Regulation Deter Entrepreneurship and Job Creation? Evidence from Recent Reforms in Portugal,” NBER Working Paper, No. 16473.

Braun, M. (2002), “Financial Contractibility and Asset Hardness”, mimeo.

Cacciatore, M. and G. Fiori (2010), "Macroeconomic Effects of Product and Labor Market (de) Regulation: the Long and Short of Reforming Europe”, mimeo.

Cacciatore, M. R. Duval, and G. Fiori (2012), "Short-term pain or GAIN? A DSGE model-based analysis of the short-term effects of structural reforms in labour and product markets", OECD Economics Department Working Papers, No.948.

Cerra, V. and S.C. Saxena (2009), "Growth Dynamics: The Myth of Economic Recovery”, American Economic Review, No. 98, pp. 439-457. 
Conway, P. and G. Nicoletti (2006), "Product Market Regulation in the Non-Manufacturing Sectors of OECD Countries: Measurement and Highlights”, OECD Economics Department Working Papers, No. 530.

De Bandt, O. and O. Vigna (2008), “The Macroeconomic Impact of Structural Reforms”, Banque de France Bulletin Digest, No.0169, January 2008.

De Serres, A. F. Murtin, and C. De la Maisonneuve, (2012), "Policies to Facilitate the Return to Work", OECD Economics Department Working Papers, forthcoming.

Duval, R. (2003), “The Retirement Effects of Old-Age Pension and Early Retirement Schemes in OECD Countries”, OECD Economics Department Working Papers, No. 370, OECD Publishing.

Duval, R. (2008), "Is There a Role for Macroeconomic Policy in Fostering Structural Reforms? Panel Evidence from OECD Countries Over the Past Two Decades”, European Journal of Political Economy, Vol. 24, No. 2, pp. 491-502, June.

Duval, R., J. Elmeskov and L. Vogel (2007), "Structural Policies and Economic Resilience to Shocks", OECD Economics Department Working Papers, No. 567.

Duval, R. and L. Vogel (2007), "How do Nominal and Real Rigidities Interact? A Tale of Second Best”, MPRA Paper No. 27362, Munich.

Eggertsson, G. (2010), ”The Paradox of Toil”, Federal Reserve Staff of New York Reports, No. 433.

Everaert, L. (2007), "Does it Pay to Synchronize Structural Reforms Across Markets and Countries? Insights from the Global Economic Model”, International Monetary Fund.

Everaert, L. and W. Schule (2008), "Why it Pays to Synchronize Structural Reforms in the Euro Area across Markets and Countries”, IMF Staff papers, Vol. 55, No. 2.

Fernandez-Villaverde, J. , P.A. Guerron-Quintana, and J. Rubio-Ramirez (2011), 'Supply-Side Policies and the Zero Lower Bound'’, NBER Working Paper, No. 17543.

Fiori, G., G. Nicoletti, and S. Scarpetta (2008), "Employment Outcomes and the Interaction between Product and Labor Market Deregulation: Are they Substitutes or Complements?”Paper presented at the IMF conference on the "Causes and Consequences of Structural Reforms", February 28-29, 2008.

Furceri, D. and A. Mourougane (2009), "The Effect of Financial Crisis on Potental Output”, OECD Economics Department Working Papers, No. 699.

Geerdsen, L.P and A. Holms (2007), "Duration of UI Periods and the Perceived Threat Effect from Labour Market Programmes”, Labour Economics, Vol. 14, pp. 639-652.

Gemmell, No., R. Kneller and I. Sanz (2011), "The Timing and Persistence of Fiscal Policy Impacts on Growth: Evidence from OECD Countries”, The Economic Journal, No. 121, pp. 33-58.

Giavazzi, F. and M. Pagano (1990), "Can Severe Fiscal Contractions be Expansionary? Tales of Two Small European Countries”, NBER Macro Annual 5, pp. 75-111.

Gomes, S., P. Jacquinot, M. Mohr, and M. Pisani (2011), "Structural Reforms and Macroeconomic Performance in the Euro Area Countries : a model-base assessment”, ECB Working Paper Series, No. 1323.

Greene, W. (2000), Econometric Analysis, Prentice Hall edition. 
Griffith, R., R. Harrison, and G. Macartney (2007), "Product Market Reforms, Labour Market Institutions and Unemployment, Economic Journal, 117, March, pp. 142-166.

Griffith, R., R. Harrison and H. Simpson (2006), "Product Market Reform and Innovation in the EU”, CEPR Discussion Paper, No. 5849.

Hobza, A. and G. Mourre (2010), "Quantifying the Potential Macroeconomic Effects of the Europe 2020 Strategy: Stylized Scenarios”, European Commission Economic Papers 424.

Høj, J., V. Galasso, G. Nicoletti and T.T. Dang (2006), “The Political Economy of Structural Reform: Empirical Evidence from OECD Countries”, OECD Economics Department Working Papers, No. 501.

Holden, S. (1994). Wage Bargaining and Nominal Rigidities, European Economic Review, Vol. 38, pp. 1021-1039.

Holden (2004), “The Costs of Price Stability: Downward Nominal Wage Rigidity in Europe”, Economica, Vol. 71, Issue 82, pp. 183-208.

IMF (2010), “Will it hurt? Macroeconomic Effects of Fiscal Consolidation”, Chapter 3 of World Economic Outlook, October 2010.

Kerdrain, C., I. Koske, and I. Wanner (2010), “The Impact of Structural Policies on Saving, Investment and Current Accounts”, OECD Economics Department Working Papers, No. 615.

Kluve, J. (2010), “The Effectiveness of European Active Labour Market Programs”, Labour Economics, Vol. 17, Issue 6, pp. 904-918.

Laeven, L. and F. Valencia (2008), "Systemic Banking Crises: A New Database”, IMF Working Paper, No. 224.

Levy-Yeyati, E. and F. Sturzenegger (2005), "Classifying Exchange Rate Regimes: Deeds vs. Words,” European Economic Review, Vol. 49(6), pp. 1603-1635.

Messina, J., P. Du Caju, C.F. Duarte, N. Lynggard Hansen, and M. Izquierdo (2010), "The Incidence of Nominal and Real Wage Rigidity: an Individual-based Sectoral Approach”, Documentos de Trabajo, No. 1022, Banco de Espana.

Mishkin, F. (2007), "Housing and the Monetary Transmission Mechanism”, NBER Working Paper, No. 13518.

Mortensen, D T and C. A. Pissarides (1994), "Job Creation and Job Destruction in the Theory of Unemployment”, Review of Economic Studies, No. 61, Vol. 3, pp. 397-415.

Mourougane, A. and L. Vogel (2008), "Speed of Adjustment to Selected Labour and Tax Reforms", OECD Economics Department Working Papers, No. 647, OECD Publishing.

Nickell, S. (1981), "Biases in Dynamic Models with Fixed Effects”, Econometrica, Vol. 49, pp. 14171426.

Nicoletti, G. and S. Scarpetta (2003), "Regulation, Productivity and Growth: OECD Evidence”, Economic Policy, 36 (April).

Nicoletti, G. and S. Scarpetta (2005), Product Market Reforms and Employment in OECD Countries," OECD Economics Department Working Papers, No. 472, OECD Publishing. 
OECD (2007), “Activating the Unemployed: What Countries Do”, Chapter 5 in OECD Employment Outlook 7, OECD Publishing.

OECD (2009), OECD Employment Outlook 2009: Tackling the Job Crisis, OECD Publishing.

OECD (2010), OECD Employment Outlook 2010: Moving Beyond the Job Crisis, OECD Publishing.

Palangkaraya, A. and J. Yong (2011), "Trade Liberalisation, Exit, and Output and Employment Adjustments of Australian Manufacturing Establishments,” The World Economy (2011).

Rajan, R. and L. Zingales (1998), "Financial Dependence and Growth,” American Economic Review, Vol. 88(3), pp. 559-86.

Romer, C. and D. H. Romer (2010), “The Macroeconomic Effects of Tax Changes: Estimates Based on a New Measure of Fiscal Shocks”, American Economic Review, No. 100, pp. 763-801.

Saint-Paul, G. and S. Bentolila (2000), “Will EMU increase Eurosclerosis?”, CEPR Discussion Paper, No. 2423.

Sutherland, D., P. Hoeller, B. Egert, and O. Rohn (2010), "Counter-cyclical Economic Policy”, OECD Economics Department Working Papers, No. 760.

Sutherland, D., P. Hoeller, R. Merola, M. Molnar, and R. Hagemann (2011), "Fiscal Consolidation”, OECD Economics Department Working Papers, forthcoming.

Teulings, C. and N. Zubanov (2010), "Is Economic Recovery a Myth? Robust Estimation of Impulse Responses,” CEPR Discussion Paper, No. 7800.

Werner, R. and J. in't Veld (2002), “Some Selected Simulation Experiments with the European Commission's QUEST Model”, European Commission, Directorate-General for Economic and Financial Affairs, Economic Papers, No. 178.

Wooldridge (2005), Econometric Analysis of Cross-section and Panel Data, MIT Press. 


\section{ANNEX - SOURCES, DEFINITION, AND COVERAGE OF VARIABLES}

Table A1. Sources, definition, and coverage of dependent variables

\begin{tabular}{|c|c|c|c|}
\hline Dependent variable & Definition & $\begin{array}{l}\text { Country and } \\
\text { time coverage }\end{array}$ & Source \\
\hline GDP growth & Annual growth rate of GDP, constant prices & OECD countries & $\begin{array}{l}\text { OECD, Economic } \\
\text { Outlook database }\end{array}$ \\
\hline Investment growth & $\begin{array}{l}\text { Annual growth rate of private total fixed } \\
\text { capital formation, volume }\end{array}$ & OECD countries & $\begin{array}{l}\text { OECD, Economic } \\
\text { Outlook database }\end{array}$ \\
\hline Consumption growth & $\begin{array}{l}\text { Annual growth rate of final consumption } \\
\text { expenditure of households, constant prices, } \\
\text { OECD base year }\end{array}$ & OECD countries & $\begin{array}{l}\text { OECD, Economic } \\
\text { Outlook database }\end{array}$ \\
\hline Aggregate employment rate & $\begin{array}{l}\text { Employment rate of population aged 15-64 } \\
\text { (employment/population), in \%. }\end{array}$ & OECD countries & $\begin{array}{l}\text { OECD, Database on } \\
\text { Labour Force Statistics; } \\
\text { OECD, Annual Labour } \\
\text { Force Statistics }\end{array}$ \\
\hline Youth employment rate & $\begin{array}{l}\text { Employment rate of population aged 15-24 } \\
\text { (in \%) }\end{array}$ & OECD countries & $\begin{array}{l}\text { OECD, Database on } \\
\text { Labour Force Statistics; } \\
\text { OECD, Annual Labour } \\
\text { Force Statistics }\end{array}$ \\
\hline Female employment rate & $\begin{array}{l}\text { Employment rate of female population aged } \\
15-64 \text { (in \%) }\end{array}$ & OECD countries & $\begin{array}{l}\text { OECD, Database on } \\
\text { Labour Force Statistics; } \\
\text { OECD, Annual Labour } \\
\text { Force Statistics }\end{array}$ \\
\hline Senior employment rate & $\begin{array}{l}\text { Employment rate of population aged 55-64 } \\
\text { (in \%) }\end{array}$ & OECD countries & $\begin{array}{l}\text { OECD, Database on } \\
\text { Labour Force Statistics; } \\
\text { OECD, Annual Labour } \\
\text { Force Statistics }\end{array}$ \\
\hline Aggregate unemployment rate & $\begin{array}{l}\text { Unemployment rate of population aged 15-64 } \\
\text { (in \%) }\end{array}$ & OECD countries & $\begin{array}{l}\text { OECD, Database on } \\
\text { Labour Force Statistics; } \\
\text { OECD, Annual Labour } \\
\text { Force Statistics }\end{array}$ \\
\hline Youth unemployment rate & $\begin{array}{l}\text { Unemployment rate of population aged 15-24 } \\
\text { (in \%) }\end{array}$ & OECD countries & $\begin{array}{l}\text { OECD, Database on } \\
\text { Labour Force Statistics; } \\
\text { OECD, Annual Labour } \\
\text { Force Statistics }\end{array}$ \\
\hline Female unemployment rate & $\begin{array}{l}\text { Unemployment rate of female population } \\
\text { aged 15-64 (in \%) }\end{array}$ & OECD countries & $\begin{array}{l}\text { OECD, Database on } \\
\text { Labour Force Statistics; } \\
\text { OECD, Annual Labour } \\
\text { Force Statistics }\end{array}$ \\
\hline Senior unemployment rate & $\begin{array}{l}\text { Unemployment rate of population aged 55-64 } \\
\text { (in \%) }\end{array}$ & OECD countries & $\begin{array}{l}\text { OECD, Database on } \\
\text { Labour Force Statistics; } \\
\text { OECD, Annual Labour } \\
\text { Force Statistics }\end{array}$ \\
\hline Aggregate participation rate & $\begin{array}{l}\text { Participation rate of population aged 15-64 } \\
\text { (in \%) }\end{array}$ & OECD countries & $\begin{array}{l}\text { OECD, Database on } \\
\text { Labour Force Statistics; } \\
\text { OECD, Annual Labour } \\
\text { Force Statistics }\end{array}$ \\
\hline Youth participation rate & $\begin{array}{l}\text { Participation rate of population aged 15-24 } \\
\text { (in \%) }\end{array}$ & OECD countries & $\begin{array}{l}\text { OECD, Database on } \\
\text { Labour Force Statistics; } \\
\text { OECD, Annual Labour } \\
\text { Force Statistics }\end{array}$ \\
\hline Female participation rate & $\begin{array}{l}\text { Participation rate of female population aged } \\
15-64 \text { (in \%) }\end{array}$ & OECD countries & $\begin{array}{l}\text { OECD, Database on } \\
\text { Labour Force Statistics; } \\
\text { OECD, Annual Labour } \\
\text { Force Statistics }\end{array}$ \\
\hline Senior participation rate & $\begin{array}{l}\text { Participation rate of population aged 55-64 } \\
\text { (in \%) }\end{array}$ & OECD countries & $\begin{array}{l}\text { OECD, Labour Force } \\
\text { Statistics database; } \\
\text { OECD, Annual Labour } \\
\text { Force Statistics }\end{array}$ \\
\hline
\end{tabular}


ECO/WKP(2012)26

Table A2. Sources, definition, and coverage of policy indicators

\begin{tabular}{|c|c|c|c|}
\hline Policy Indicator & Definition & Country and time coverage & Source \\
\hline $\begin{array}{l}\text { Unemployment } \\
\text { benefit } \\
\text { replacement rate, } \\
1^{\text {st }} \text { year }\end{array}$ & $\begin{array}{l}\text { Initial gross unemployment } \\
\text { benefit replacement rate (in } \\
\%)\end{array}$ & $\begin{array}{l}\text { 1982-2007 for all OECD countries except Chile } \\
\text { (na), Czech Republic (2001-2007), Greece (1985- } \\
\text { 1997), Estonia (na), Hungary (2001-2007), Iceland } \\
\text { (na), Korea (2001-2007), Luxembourg (2001-2007), } \\
\text { Mexico (na), Poland (2001-2007), Slovak Republic } \\
\text { (2001-2007) }\end{array}$ & $\begin{array}{l}\text { OECD, Benefits and } \\
\text { Wages database }\end{array}$ \\
\hline $\begin{array}{l}\text { Unemployment } \\
\text { benefit } \\
\text { replacement rate, } \\
5 \text { years }\end{array}$ & $\begin{array}{l}\text { Average of the gross } \\
\text { unemployment benefit } \\
\text { replacement rates for two } \\
\text { earnings levels, three family } \\
\text { situations and three durations } \\
\text { of unemployment, summary } \\
\text { measure of benefit } \\
\text { entitlements, 1961-2007 (in } \\
\% \text { ) }\end{array}$ & $\begin{array}{l}\text { 1961-2007 for all OECD countries, except Chile } \\
\text { (na), Czech Republic (na), Estonia (na), Hungary } \\
\text { (na), Iceland (2001-2007), Korea (na), Luxembourg } \\
\text { (na), Mexico (na), Poland (2001-2007), Slovak } \\
\text { Republic (na), Slovenia (na), Turkey (na). }\end{array}$ & $\begin{array}{l}\text { OECD, Benefits and } \\
\text { Wages database }\end{array}$ \\
\hline $\begin{array}{l}\text { Duration of } \\
\text { unemployment } \\
\text { benefits }\end{array}$ & $\begin{array}{l}\text { Indicator of the evolution of } \\
\text { the unemployment benefit } \\
\text { replacement rate across } \\
\text { unemployment spell (ratio of } \\
\text { average unemployment } \\
\text { replacement rates over the } \\
\text { five first years of } \\
\text { unemployment to benefit } \\
\text { replacement rate for the first } \\
\text { year of unemployment) }\end{array}$ & $\begin{array}{l}\text { 1982-2007 for all OECD countries except Chile } \\
\text { (na), Czech Republic (2001-2007), Greece (1985- } \\
\text { 1997), Estonia (na), Hungary (2001-2007), Iceland } \\
\text { (na), Korea (2001-2007), Luxembourg (2001-2007), } \\
\text { Mexico (na), Poland (2001-2007), Slovak Republic } \\
\text { (2001-2007), Slovenia (na), Turkey (na). }\end{array}$ & $\begin{array}{l}\text { OECD, Benefits and } \\
\text { Wages database and } \\
\text { authors' calculations }\end{array}$ \\
\hline $\begin{array}{l}\text { Job protection on } \\
\text { temporary } \\
\text { workers }\end{array}$ & $\begin{array}{l}\text { Strictness of Employment } \\
\text { Protection of temporary } \\
\text { employment, 1985/2008 } \\
\text { (index from } 0 \text { to 6) }\end{array}$ & $\begin{array}{l}\text { 1985-2008 for all OECD countries, except Chile } \\
\text { (2008), Czech Republic (1993-2008), Estonia } \\
\text { (2008), Hungary (1990-2008), Iceland (2008), } \\
\text { Korea (1990-2008), Luxembourg (2008), Mexico } \\
\text { (1990-2008), New Zealand (1990-2008), Poland } \\
\text { (1990-2008), Slovak Republic (1993-2008), } \\
\text { Slovenia (2008), Turkey (1990-2008) }\end{array}$ & $\begin{array}{l}\text { OECD, Labour Force } \\
\text { Statistics database }\end{array}$ \\
\hline $\begin{array}{l}\text { Job protection on } \\
\text { regular workers }\end{array}$ & $\begin{array}{l}\text { Strictness of Employment } \\
\text { Protection of regular } \\
\text { employment, 1985/2008 } \\
\text { (index from } 0 \text { to 6) }\end{array}$ & $\begin{array}{l}\text { 1985-2008 for all OECD countries, except Chile } \\
\text { (2008), Czech Republic (1993-2008), Estonia } \\
\text { (2008), Hungary (1990-2008), Iceland (2008), } \\
\text { Korea (1990-2008), Luxembourg (2008), Mexico } \\
\text { (1990-2008), New Zealand (1990-2008), Poland } \\
\text { (1990-2008), Slovak Republic (1993-2008), } \\
\text { Slovenia (2008), Turkey (1990-2008) }\end{array}$ & $\begin{array}{l}\text { OECD, Labour Force } \\
\text { Statistics database }\end{array}$ \\
\hline $\begin{array}{l}\text { Labour tax } \\
\text { wedge }\end{array}$ & $\begin{array}{l}\text { Combined labour and } \\
\text { consumption tax rate derived } \\
\text { from National Accounts }\end{array}$ & $\begin{array}{l}\text { 1985-2007 for all OECD countries, except Czech } \\
\text { Republic (1993-2007), Estonia (2008), Greece } \\
\text { (1995-1997), Hungary (1995-2007), Iceland (n.a.), } \\
\text { Japan (1990-2007), Korea (2000-2007), } \\
\text { Luxembourg (n.a.), Mexico (n.a.), New Zealand } \\
\text { (n.a.), Poland (1996-2008), Slovak Republic (1998- } \\
\text { 2007), Slovenia (n.a.), Switzerland (1991-2007), } \\
\text { Turkey (n.a.). }\end{array}$ & $\begin{array}{l}\text { OECD, Taxing Wages } \\
\text { database }\end{array}$ \\
\hline $\begin{array}{l}\text { Product market } \\
\text { regulation in } \\
\text { seven non- } \\
\text { manufacturing } \\
\text { industries }\end{array}$ & $\begin{array}{l}\text { OECD summary indicator of } \\
\text { regulatory impediments to } \\
\text { product market competition } \\
\text { in seven non-manufacturing } \\
\text { industries. This indicator } \\
\text { covers regulations and market } \\
\text { conditions in seven energy } \\
\text { and service industries: gas, } \\
\text { electricity, post, telecoms } \\
\text { (mobile and fixed services), } \\
\text { passenger air transport, }\end{array}$ & $\begin{array}{l}24 \text { OECD countries (1975-2007) with missing data } \\
\text { for Czech Republic (data n.a. over 1991-1997), } \\
\text { Germany (1991-1997), Hungary (1991-1997), } \\
\text { Norway (1999-2002), Poland (1991-1997), Portugal } \\
\text { (1999-2002), Slovak Republic (1991-2002), Spain } \\
\text { (1988-1997). Other OECD countries are Austria } \\
\text { (data over 1990-2007), Iceland (1998-2007), Korea } \\
\text { (1998-2007), Luxembourg (1998-2007), Mexico } \\
\text { (1998-2007), Turkey (1998-2007). }\end{array}$ & $\begin{array}{l}\text { OECD, Product } \\
\text { Market Regulation } \\
\text { database } \\
\text { www.oecd.org/eco/pmr } \\
\text { described in Conway, } \\
\text { P., D. De Rosa, G. } \\
\text { Nicoletti, and F. } \\
\text { Steiner (2006), } \\
\text { "Regulation, } \\
\text { competition, and } \\
\text { productivity }\end{array}$ \\
\hline
\end{tabular}




\begin{tabular}{|c|c|c|c|}
\hline & $\begin{array}{l}\text { railways (passenger and } \\
\text { freight services) and road } \\
\text { freight (index from } 0 \text { to 6). }\end{array}$ & & $\begin{array}{l}\text { convergence", OECD } \\
\text { Economics Department } \\
\text { Working Paper No. } \\
509 .\end{array}$ \\
\hline $\begin{array}{l}\text { Standard } \\
\text { retirement age }\end{array}$ & $\begin{array}{l}\text { Standard age of eligibility to } \\
\text { old-age pension benefits (in } \\
\text { years) }\end{array}$ & $\begin{array}{l}\text { 1967-1999 for all OECD countries, except Australia } \\
\text { (1967-2008), Austria (1999), Belgium (1995-2008), } \\
\text { Chile (n.a.), Czech Republic (n.a.), Denmark (n.a.), } \\
\text { Estonia (2008), Greece (n.a.), Hungary (n.a.), } \\
\text { Iceland (1995-1999), Japan (1993-1999), Korea } \\
\text { (n.a.), Luxembourg (1993-1999), Mexico (n.a.), } \\
\text { New Zealand (1977-1999), Poland (n.a.), Slovak } \\
\text { Republic (n.a.), Slovenia (n.a.), Switzerland (1989- } \\
\text { 1999), Turkey (n.a.). }\end{array}$ & $\begin{array}{l}\text { Duval R. (2004), } \\
\text { "Retirement Behaviour } \\
\text { in OECD Countries: } \\
\text { Impact of Old-age } \\
\text { Pension Schemes and } \\
\text { Other Social Transfer } \\
\text { Programmes", OECD } \\
\text { Economic Studies, No. } \\
37 .\end{array}$ \\
\hline $\begin{array}{l}\text { Minimum } \\
\text { retirement age }\end{array}$ & $\begin{array}{l}\text { Minimum age of eligibility to } \\
\text { old-age pension benefits (in } \\
\text { years) }\end{array}$ & $\begin{array}{l}\text { 1967-1999 for all OECD countries, except Australia } \\
\text { (1967-2008), Austria (1999), Belgium (1995-2008), } \\
\text { Chile (n.a.), Czech Republic (n.a.), Denmark (n.a.), } \\
\text { Estonia (2008), Greece (n.a.), Hungary (n.a.), } \\
\text { Iceland (1995-1999), Japan (1993-1999), Korea } \\
\text { (n.a.), Luxembourg (1993-1999), Mexico (n.a.), } \\
\text { New Zealand (1977-1999), Poland (n.a.), Slovak } \\
\text { Republic (n.a.), Slovenia (n.a.), Switzerland (1989- } \\
\text { 1999), Turkey (n.a.). }\end{array}$ & $\begin{array}{l}\text { Duval R. (2004), } \\
\text { "Retirement Behaviour } \\
\text { in OECD Countries: } \\
\text { Impact of Old-age } \\
\text { Pension Schemes and } \\
\text { Other Social Transfer } \\
\text { Programmes", OECD } \\
\text { Economic Studies, No. } \\
37 .\end{array}$ \\
\hline $\begin{array}{l}\text { Implicit tax rate } \\
\text { on continued } \\
\text { work in early } \\
\text { retirement } \\
\text { pathway }\end{array}$ & $\begin{array}{l}\text { Implicit tax rates on } \\
\text { continued work between age } \\
55 \text { and } 60 \text { in early retirement } \\
\text { pathways. }\end{array}$ & $\begin{array}{l}\text { 1967-1999 for all OECD countries, except Austria } \\
\text { (1999), Belgium (1995-1999), Chile (n.a.), Czech } \\
\text { Republic (n.a.), Denmark (n.a.), Estonia (2008), } \\
\text { Greece (n.a.), Hungary (n.a.), Iceland (1995-1999), } \\
\text { Japan (1993-1999), Korea (1987-1999), } \\
\text { Luxembourg (1993-1999), Mexico (n.a.), New } \\
\text { Zealand (1977-1999), Poland (n.a.), Slovak } \\
\text { Republic (n.a.), Slovenia (n.a.), Switzerland (1989- } \\
\text { 1999), Turkey (n.a.). }\end{array}$ & $\begin{array}{l}\text { Original data on } \\
\text { implicit taxes on } \\
\text { continued work for } \\
\text { various age groups in } \\
\text { both early retirement } \\
\text { pathways and old-age } \\
\text { pension schemes are } \\
\text { described in detail in } \\
\text { Duval R. (2004), } \\
\text { "Retirement Behaviour } \\
\text { in OECD Countries: } \\
\text { Impact of Old-age } \\
\text { Pension Schemes and } \\
\text { Other Social Transfer } \\
\text { Programmes, OECD } \\
\text { Economic Studies, No. } \\
\text { 37. }\end{array}$ \\
\hline $\begin{array}{l}\text { Summary } \\
\text { implicit tax rate } \\
\text { on continued } \\
\text { work }\end{array}$ & $\begin{array}{l}\text { Weighted average of implicit } \\
\text { tax rates on continued work } \\
\text { between age } 55 \text { and } 60 \text { in } \\
\text { early retirement pathways } \\
\text { (50\%) and between age } 60 \\
\text { and } 65 \text { in both early } \\
\text { retirement pathways (25\%) } \\
\text { and old-age pension schemes } \\
(25 \%) \text {. This variable can be } \\
\text { interpreted as a summary } \\
\text { measure of retirement } \\
\text { incentives facing the age } \\
\text { group } 55-64 \text { (in \%). }\end{array}$ & $\begin{array}{l}\text { 1967-1999 for all OECD countries, except Austria } \\
\text { (1999), Belgium (1995-1999), Chile (n.a.), Czech } \\
\text { Republic (n.a.), Denmark (n.a.), Estonia (2008), } \\
\text { Greece (n.a.), Hungary (n.a.), Iceland (1995-1999), } \\
\text { Japan (1993-1999), Korea (1987-1999), } \\
\text { Luxembourg (1993-1999), Mexico (n.a.), New } \\
\text { Zealand (1977-1999), Poland (n.a.), Slovak } \\
\text { Republic (n.a.), Slovenia (n.a.), Switzerland (1989- } \\
\text { 1999), Turkey (n.a.). }\end{array}$ & $\begin{array}{l}\text { Original data on } \\
\text { implicit taxes on } \\
\text { continued work for } \\
\text { various age groups in } \\
\text { both early retirement } \\
\text { pathways and old-age } \\
\text { pension schemes are } \\
\text { described in detail in } \\
\text { Duval R. (2004), } \\
\text { "Retirement Behaviour } \\
\text { in OECD Countries: } \\
\text { Impact of Old-age } \\
\text { Pension Schemes and } \\
\text { Other Social Transfer } \\
\text { Programmes", OECD } \\
\text { Economic Studies, No. } \\
\text { 37. }\end{array}$ \\
\hline Tax structure & $\begin{array}{l}\text { Ratio of taxes on income, } \\
\text { profits and capital gains, } \\
\text { social security contributions, } \\
\text { and taxes on payroll and } \\
\text { workforce (OECD categories } \\
\text { 1000, 2000, and 3000, } \\
\end{array}$ & $\begin{array}{l}\text { 1965-2007/2008 for all OECD countries except } \\
\text { Chile (n.a.), Czech Republic (1993-2008), Hungary } \\
\text { (1991-2008), Iceland (1980-2008), Korea (1972- } \\
\text { 2008), Mexico (1980-2008), Poland (1991-2007), } \\
\text { Slovak Republic (1998-2008), Slovenia (n.a.). }\end{array}$ & $\begin{array}{l}\text { OECD, Tax Revenue } \\
\text { Statistics database }\end{array}$ \\
\hline
\end{tabular}


ECO/WKP(2012)26

\begin{tabular}{|c|c|c|c|}
\hline & $\begin{array}{l}\text { respectively) in total tax } \\
\text { revenues (in \%). }\end{array}$ & & \\
\hline $\begin{array}{l}\text { Total tax } \\
\text { revenue }\end{array}$ & $\begin{array}{l}\text { Ratio of total tax revenue to } \\
\text { GDP (in \%). }\end{array}$ & $\begin{array}{l}\text { 1965-2007/2008 for all OECD countries except } \\
\text { Chile (n.a.), Czech Republic (1993-2008), Hungary } \\
\text { (1991-2008), Iceland (1980-2008), Korea (1972- } \\
\text { 2008), Mexico (1980-2008), Poland (1991-2007), } \\
\text { Slovak Republic (1998-2008), Slovenia (n.a.). }\end{array}$ & $\begin{array}{l}\text { OECD, Tax Revenue } \\
\text { Statistics database }\end{array}$ \\
\hline $\begin{array}{l}\text { Active labour } \\
\text { market policy } \\
\text { spending, } \\
\text { training }\end{array}$ & $\begin{array}{l}\text { Active labour market policy } \\
\text { spending on training per } \\
\text { unemployed over GDP per } \\
\text { capita, adjusted for the } \\
\text { unemployment gap (in \%) }\end{array}$ & $\begin{array}{l}\text { 1985-2007 for all OECD countries, except Chile } \\
\text { (n.a.), Czech Republic (1994-2007), Denmark } \\
\text { (1986-2007), Greece (1995-1997), Hungary (1995- } \\
\text { 2007), Iceland (n.a.), Italy (2004-2007), Japan } \\
\text { (1990-2007), Korea (2000-2007), Luxembourg } \\
\text { (1985-1997 and 2002-2007), Mexico (n.a.), Poland } \\
\text { (1995-2007), Slovak Republic (1994-2007), } \\
\text { Slovenia (n.a.), Switzerland (1991-2007), Turkey } \\
\text { (n.a.). }\end{array}$ & $\begin{array}{l}\text { OECD calculations } \\
\text { based on OECD } \\
\text { Employment Outlook } \\
\text { database }\end{array}$ \\
\hline $\begin{array}{l}\text { Active labour } \\
\text { market policy } \\
\text { spending, } \\
\text { employment } \\
\text { incentives }\end{array}$ & $\begin{array}{l}\text { Active labour market policy } \\
\text { spending on employment } \\
\text { incentives per unemployed } \\
\text { over GDP per capita, adjusted } \\
\text { for the unemployment gap (in } \\
\%)\end{array}$ & $\begin{array}{l}\text { 1985-2007 for all OECD countries, except Chile } \\
\text { (n.a.), Czech Republic (1994-2007), Denmark } \\
\text { (1986-2007), Greece (1995-1997), Hungary (1995- } \\
\text { 2007), Iceland (n.a.), Italy (2004-2007), Japan } \\
\text { (1990-2007), Korea (2000-2007), Luxembourg } \\
\text { (1985-1997 and 2002-2007), Mexico (n.a.), Poland } \\
\text { (1995-2007), Slovak Republic (1994-2007), } \\
\text { Slovenia (n.a.), Switzerland (1991-2007), Turkey } \\
\text { (n.a.). }\end{array}$ & $\begin{array}{l}\text { OECD calculations } \\
\text { based on OECD } \\
\text { Employment Outlook } \\
\text { database }\end{array}$ \\
\hline $\begin{array}{l}\text { "Excess" } \\
\text { coverage of } \\
\text { collective } \\
\text { bargaining }\end{array}$ & $\begin{array}{l}\text { Difference between trade } \\
\text { union coverage (defined as } \\
\text { the percentage of employees } \\
\text { covered by collective } \\
\text { bargaining provisions) and } \\
\text { trade union density (defined } \\
\text { as the percentage of } \\
\text { employees who are members } \\
\text { of a trade-union), in \%. }\end{array}$ & $\begin{array}{l}\text { OECD countries except Chile, Estonia, Greece, } \\
\text { Iceland, Italy, Mexico, Slovenia, and Turkey. }\end{array}$ & $\begin{array}{l}\text { OECD, Employment } \\
\text { Outlook database }\end{array}$ \\
\hline $\begin{array}{l}\text { Primary fiscal } \\
\text { balance }\end{array}$ & $\begin{array}{l}\text { Cyclically-adjusted } \\
\text { government primary balance, } \\
\text { as a percentage of GDP (in } \\
\%)\end{array}$ & OECD countries except Chile, Mexico, and Turkey. & $\begin{array}{l}\text { OECD, Economic } \\
\text { Outlook database }\end{array}$ \\
\hline $\begin{array}{l}\text { Real short-term } \\
\text { interest rate }\end{array}$ & $\begin{array}{l}\text { Difference between the short- } \\
\text { term interest rate and inflation }\end{array}$ & $\begin{array}{l}\text { OECD countries except Chile, Estonia, and } \\
\text { Slovenia. }\end{array}$ & $\begin{array}{l}\text { OECD, Economic } \\
\text { Outlook database }\end{array}$ \\
\hline $\begin{array}{l}\text { Underlying } \\
\text { primary fiscal } \\
\text { balance }\end{array}$ & $\begin{array}{l}\text { Underlying general } \\
\text { government primary fiscal } \\
\text { balance (as a share of } \\
\text { potential GDP) }\end{array}$ & $\begin{array}{l}\text { OECD countries except Chile, Estonia, Mexico, and } \\
\text { Turkey. }\end{array}$ & $\begin{array}{l}\text { OECD, Economic } \\
\text { Outlook database }\end{array}$ \\
\hline $\begin{array}{l}\text { Exchange rate } \\
\text { regime }\end{array}$ & $\begin{array}{l}\text { Exchange Rate Classification } \\
\text { (de facto), index from } 1 \text { to } 5 \\
\text { (from floating to fixed } \\
\text { regime) }\end{array}$ & OECD countries. & $\begin{array}{l}\text { Levy-Yeyati and } \\
\text { Sturzenegger (LYS) de } \\
\text { facto classification of } \\
\text { exchange rate regimes } \\
\text { database described in } \\
\text { Levy-Yeyati and } \\
\text { Sturzenegger (2005), } \\
\text { "Deeds vs. Words: } \\
\text { Classifying Exchange } \\
\text { Rate Regimes", } \\
\text { European Economic } \\
\text { Review 49, pp. 1603- } \\
\text { 1635. }\end{array}$ \\
\hline
\end{tabular}


Table A3. Descriptive statistics of the reform shocks

\begin{tabular}{|c|c|c|c|c|c|}
\hline Reform area & $\begin{array}{l}\text { Number of } \\
\text { reform } \\
\text { shocks }\end{array}$ & Mean & $\begin{array}{l}\text { Standard } \\
\text { deviation }\end{array}$ & Minimum & Maximum \\
\hline $\begin{array}{l}\text { Decline in unemployment benefit replacement } \\
\text { rate, } 1^{\text {st }} \text { year }(\%)\end{array}$ & 16 & 8.55 & 2.93 & 5.50 & 14.75 \\
\hline $\begin{array}{l}\text { Decline in unemployment benefit replacement } \\
\text { rate, } 5 \text { years (\%) }\end{array}$ & 8 & 7.60 & 4.75 & 4.38 & 17.31 \\
\hline Decline in duration of unemployment benefits & 5 & 0.16 & 0.05 & 0.13 & 0.24 \\
\hline Decline in job protection on regular workers & 2 & 0.99 & 0.18 & 0.86 & 1.11 \\
\hline Decline in job protection on temporary workers & 6 & 1.68 & 0.31 & 1.19 & 2.00 \\
\hline Decline in labour tax wedge (\%) & 25 & 2.91 & 0.90 & 1.89 & 5.55 \\
\hline $\begin{array}{l}\text { Decline in the share of income tax in total tax } \\
\text { revenues (\%) }\end{array}$ & 31 & 3.56 & 1.81 & 2.28 & 10.03 \\
\hline $\begin{array}{l}\text { Decline in cyclically adjusted active labour } \\
\text { market policy spending, training (\%) }\end{array}$ & 27 & 5.33 & 1.97 & 3.30 & 10.78 \\
\hline $\begin{array}{l}\text { Increase in cyclically adjusted active labour } \\
\text { market policy spending, employment } \\
\text { incentives (\%) }\end{array}$ & 31 & 2.77 & 0.99 & 1.78 & 5.86 \\
\hline $\begin{array}{l}\text { Increase in "excess" coverage of collective } \\
\text { bargaining (\%) }\end{array}$ & 5 & 19.04 & 12.13 & 9.80 & 35.70 \\
\hline $\begin{array}{l}\text { Decline in product market regulation in seven } \\
\text { non-manufacturing industries }\end{array}$ & 68 & 0.49 & 0.14 & 0.40 & 0.90 \\
\hline $\begin{array}{l}\text { Decline in implicit tax rate on continued work } \\
(\%)\end{array}$ & 4 & 21.14 & 7.62 & 10.04 & 28.90 \\
\hline Increase in minimum retirement age (years) & 2 & 2.04 & 0.41 & 1.50 & 2.50 \\
\hline
\end{tabular}


ECO/WKP(2012)26

Table A4. Correlations between the reform shock variables

\begin{tabular}{|c|c|c|c|c|c|c|c|c|c|c|c|c|c|}
\hline & $\begin{array}{l}\text { Decline in } \\
\text { initial UB } \\
\text { Replacement } \\
\text { Rate }\end{array}$ & $\begin{array}{c}\text { Decline in 5- } \\
\text { year Average } \\
\text { UB } \\
\text { Replacement } \\
\text { Rate }\end{array}$ & $\begin{array}{l}\text { Decline in } \\
\text { "UB } \\
\text { Duration" }\end{array}$ & $\begin{array}{c}\text { Decline in } \\
\text { Job } \\
\text { Protection } \\
\text { on } \\
\text { Regular } \\
\text { Contracts } \\
\end{array}$ & $\begin{array}{c}\text { Decline in } \\
\text { Job } \\
\text { Protection } \\
\text { on } \\
\text { Temporary } \\
\text { Contracts } \\
\end{array}$ & $\begin{array}{c}\text { Decline } \\
\text { in } \\
\text { Labour } \\
\text { Tax } \\
\text { Wedge } \\
\end{array}$ & $\begin{array}{c}\text { Decline in } \\
\text { the Share } \\
\text { of Income } \\
\text { Tax in } \\
\text { Total Tax } \\
\text { Revenues }\end{array}$ & $\begin{array}{l}\text { Reduction } \\
\text { of "excess" } \\
\text { coverage of } \\
\text { collective } \\
\text { bargaining }\end{array}$ & $\begin{array}{l}\text { Decline in } \\
\text { Product } \\
\text { Market } \\
\text { Regulation }\end{array}$ & $\begin{array}{l}\text { Increase in } \\
\text { Spending } \\
\text { on ALMP } \\
\text { in Training }\end{array}$ & $\begin{array}{l}\text { Increase in } \\
\text { Spending } \\
\text { on ALMP in } \\
\text { Employmen } \\
\text { t Incentives }\end{array}$ & $\begin{array}{c}\text { Increase } \\
\text { in } \\
\text { Minimum } \\
\text { Retireme } \\
\text { nt Age }\end{array}$ & $\begin{array}{c}\text { Decline in } \\
\text { Implicit Tax } \\
\text { on } \\
\text { Continued } \\
\text { Work } \\
\end{array}$ \\
\hline $\begin{array}{l}\text { Decline in initial } \\
\text { UB Replacement } \\
\text { Rate }\end{array}$ & 1 & & & & & & & & & & & & \\
\hline $\begin{array}{l}\text { Decline in 5-year } \\
\text { Average UB } \\
\text { Replacement Rate }\end{array}$ & $0.09 *$ & 1 & & & & & & & & & & & \\
\hline $\begin{array}{l}\text { Decline in "UB } \\
\text { Duration" }\end{array}$ & -0.01 & $0.86^{*}$ & 1 & & & & & & & & & & \\
\hline $\begin{array}{l}\text { Decline in Job } \\
\text { Protection on } \\
\text { Regular Contracts }\end{array}$ & -0.01 & -0.00 & -0.00 & 1 & & & & & & & & & \\
\hline $\begin{array}{l}\text { Decline in Job } \\
\text { Protection on } \\
\text { Temporary } \\
\text { Contracts } \\
\end{array}$ & 0.08 & -0.01 & -0.01 & -0.01 & 1 & & & & & & & & \\
\hline $\begin{array}{l}\text { Decline in Labour } \\
\text { Tax Wedge }\end{array}$ & 0.09 & 0.07 & 0.05 & -0.01 & -0.03 & 1 & & & & & & & \\
\hline $\begin{array}{l}\text { Decline in the } \\
\text { Share of Income } \\
\text { Tax in Total Tax } \\
\text { Revenues }\end{array}$ & 0.01 & -0.02 & -0.02 & -0.01 & -0.02 & $0.27^{\star}$ & 1 & & & & & & \\
\hline $\begin{array}{l}\text { Reduction of } \\
\text { "excess"coverage } \\
\text { of collective } \\
\text { bargaining }\end{array}$ & -0.01 & -0.01 & -0.01 & -0.00 & -0.01 & -0.02 & -0.01 & 1 & & & & & \\
\hline $\begin{array}{l}\text { Decline in Product } \\
\text { Market Regulation }\end{array}$ & 0.01 & 0.03 & 0.02 &.$^{*}$ & 0.07 & 0.05 & -0.04 & 0.08 & 1 & & & & \\
\hline $\begin{array}{l}\text { Increase in } \\
\text { Spending on } \\
\text { ALMP in Training }\end{array}$ & 0.03 & -0.02 & -0.02 & -0.01 & $0.10^{\star}$ & -0.01 & $0.15^{\star}$ & -0.02 & -0.02 & 1 & & & \\
\hline $\begin{array}{l}\text { Increase in } \\
\text { Spending on } \\
\text { ALMP in } \\
\text { Employment } \\
\text { Incentives }\end{array}$ & -0.00 & -0.03 & -0.02 & -0.01 & -0.03 & 0.03 & 0.04 & -0.02 & $0.10^{*}$ & $0.16^{\star}$ & 1 & & \\
\hline $\begin{array}{l}\text { Increase in } \\
\text { Minimum } \\
\text { Retirement Age }\end{array}$ & -0.02 & -0.01 & -0.01 & -0.01 & -0.02 & .* & -0.03 & -0.02 & 0.02 & -0.04 & -0.04 & 1 & \\
\hline $\begin{array}{l}\text { Decline in Implicit } \\
\text { Tax on Continued } \\
\text { Work }\end{array}$ & -0.03 & -0.01 & -0.01 & -0.02 & $0.20^{\star}$ & -0.04 & -0.03 & -0.01 & 0.05 & -0.05 & -0.05 & $0.20^{\star}$ & 1 \\
\hline
\end{tabular}

Note: A reform shock is identified when the variation in the associated policy indicator exceeds 2 standard deviations of the annual decrease calculated over all available observations. Exceptions are retirement scheme reforms for which the procedures take phasing-in into account (see text). 
Table A5. Short-term impact of structural reforms (baseline specification)

\begin{tabular}{|c|c|c|c|c|c|c|c|c|c|c|c|c|c|c|c|}
\hline \multirow{2}{*}{$\begin{array}{l}\text { Reform shocks } \\
\text { Years after the Reform }\end{array}$} & \multicolumn{5}{|c|}{ Decline in 5-year Average UB Replacement Rate } & \multicolumn{5}{|c|}{ Decline in initial UB Replacement Rate } & \multicolumn{5}{|c|}{ Decline in "UB Duration" } \\
\hline & Y1 & Y2 & Y3 & Y4 & Y5 & $\mathrm{Y} 1$ & Y2 & Y3 & Y4 & Y5 & $\mathrm{Y} 1$ & $\mathrm{Y} 2$ & Y3 & Y4 & Y5 \\
\hline \multicolumn{16}{|l|}{ Dependent variables } \\
\hline \multirow[t]{2}{*}{ Aggregate employment } & $0.028^{* *}$ & 0.023 & 0.006 & 0.036 & 0.196 & 0.028 & 0.047 & $0.068^{* *}$ & $0.096^{* *}$ & $0.125^{* *}$ & 1.598 & 0.991 & -4.876 & 2.630 & $12.186^{*}$ \\
\hline & $(2.38)$ & $(0.66)$ & $(0.08)$ & $(0.37)$ & $(1.35)$ & $(1.61)$ & $(1.34)$ & $(2.11)$ & $(2.20)$ & $(2.65)$ & $(1.20)$ & $(0.29)$ & $(-1.38)$ & $(0.48)$ & $(1.87)$ \\
\hline \multirow[t]{2}{*}{ Youth } & 0.018 & -0.061 & 0.029 & 0.037 & 0.318 & 0.012 & 0.075 & $0.092^{*}$ & $0.131^{* *}$ & $0.179 *$ & 1.110 & -3.630 & -8.411 & 4.982 & $24.893^{*}$ \\
\hline & $(0.37)$ & $(-0.83)$ & $(0.15)$ & $(0.18)$ & $(1.56)$ & $(0.50)$ & $(1.17)$ & (1.79) & $(2.12)$ & (2.05) & $(0.32)$ & $(-0.64)$ & $(-0.84)$ & $(0.37)$ & $(1.94)$ \\
\hline \multirow[t]{2}{*}{ Women } & 0.038 & 0.023 & 0.055 & 0.124 & 0.261 & $0.043^{*}$ & $0.059 * *$ & $0.094^{* *}$ & $0.118^{*}$ & $0.176^{* * *}$ & 1.520 & 0.203 & -1.821 & 5.113 & 7.704* \\
\hline & (1.54) & $(0.57)$ & $(0.66)$ & (1.24) & $(1.47)$ & $(2.00)$ & (2.11) & (2.35) & (2.02) & (2.98) & $(0.99)$ & $(0.07)$ & $(-0.57)$ & $(1.63)$ & (1.95) \\
\hline Senior & $(1.07)$ & $(1.21)$ & $(-0.41)$ & $(-0.69)$ & $(-0.16)$ & $(-0.35)$ & (1.31) & (1.63) & (2.33) & (2.03) & $(0.00)$ & $(0.41)$ & $(-1.13)$ & $(-1.83)$ & $(-1.49)$ \\
\hline \multirow[t]{2}{*}{ Aggregate unemployment } & $-0.030^{*}$ & -0.019 & -0.000 & -0.014 & 0.006 & -0.024 & -0.021 & -0.035 & -0.059 & -0.067 & $-1.954^{*}$ & -1.756 & 0.833 & -2.954 & -5.725 \\
\hline & $(-2.03)$ & $(-0.54)$ & $(0.00)$ & $(-0.15)$ & $(0.05)$ & $(-1.46)$ & $(-0.76)$ & $(-1.23)$ & $(-1.47)$ & $(-1.25)$ & $(-1.92)$ & $(-0.63)$ & $(0.21)$ & $(-0.49)$ & $(-0.53)$ \\
\hline \multirow[t]{2}{*}{ Youth } & $-0.117^{* *}$ & -0.046 & $-0.228 * *$ & -0.153 & -0.073 & -0.034 & -0.064 & -0.064 & -0.110 & -0.130 & $-5.454 * *$ & -1.976 & $-10.731 * * *$ & -8.142 & -6.245 \\
\hline & $(-2.44)$ & $(-0.83)$ & $(-2.06)$ & $(-1.16)$ & $(-0.45)$ & $(-1.11)$ & $(-1.06)$ & $(-0.85)$ & $(-1.06)$ & $(-1.05)$ & $(-2.06)$ & $(-0.57)$ & $(-3.47)$ & $(-1.70)$ & $(-0.75)$ \\
\hline \multirow[t]{2}{*}{ Women } & -0.023 & -0.010 & 0.031 & -0.005 & 0.014 & 0.003 & $0.052^{*}$ & 0.064 & 0.051 & 0.060 & -1.585 & -1.182 & 2.834 & -2.395 & -5.860 \\
\hline & $(-1.53)$ & $(-0.22)$ & $(0.36)$ & $(-0.07)$ & $(0.15)$ & (0.15) & $(1.80)$ & (1.41) & $(1.01)$ & (1.13) & $(-1.53)$ & $(-0.40)$ & $(0.62)$ & $(-0.43)$ & $(-0.56)$ \\
\hline \multirow[t]{2}{*}{ Senior } & -0.024 & -0.002 & 0.028 & 0.046 & -0.030 & -0.043 & $-0.074^{*}$ & $-0.102 * * *$ & $-0.087^{*}$ & $-0.081^{* *}$ & -1.271 & -2.662 & 0.764 & -0.714 & -12.750 \\
\hline & $(-1.01)$ & $(-0.07)$ & $(0.34)$ & $(0.55)$ & $(-0.25)$ & $(-1.35)$ & $(-2.03)$ & $(-3.16)$ & $(-1.96)$ & $(-2.35)$ & $(-0.99)$ & $(-0.68)$ & $(0.14)$ & $(-0.10)$ & $(-0.87)$ \\
\hline Aggregate participation & $(0.01)$ & $(-0.05)$ & $(0.01)$ & $(0.09)$ & $(2.60)$ & $(0.43)$ & $(1.06)$ & $(2.50)$ & (3.06) & $(2.85)$ & $(-0.01)$ & $(-0.31)$ & $(-0.76)$ & $(-0.32)$ & $(2.07)$ \\
\hline \multirow[t]{2}{*}{ Youth } & -0.063 & -0.105 & -0.119 & -0.084 & $0.310^{*}$ & -0.015 & 0.059 & 0.075 & 0.100 & 0.136 & -2.446 & -5.468 & -16.819 & -0.727 & $23.369 * *$ \\
\hline & $(-1.37)$ & $(-1.61)$ & $(-0.55)$ & $(-0.41)$ & $(1.81)$ & $(-0.47)$ & (0.99) & (1.64) & (1.59) & (1.43) & $(-0.83)$ & $(-1.20)$ & $(-1.25)$ & $(-0.05)$ & $(2.29)$ \\
\hline \multirow[t]{2}{*}{ Women } & 0.017 & 0.017 & 0.081 & 0.091 & $0.312^{* * *}$ & 0.032 & $0.068^{* *}$ & $0.113^{* * *}$ & $0.132^{* * *}$ & $0.197^{* * *}$ & 0.375 & -0.448 & 0.206 & 1.194 & 4.556 \\
\hline & $(0.83)$ & $(0.90)$ & $(1.56)$ & $(1.68)$ & $(3.43)$ & $(1.45)$ & $(2.67)$ & (3.13) & $(3.07)$ & $(4.34)$ & $(0.36)$ & $(-0.25)$ & $(0.04)$ & $(0.25)$ & $(0.37)$ \\
\hline \multirow[t]{2}{*}{ Senior } & 0.019 & 0.100 & -0.043 & -0.073 & -0.000 & -0.035 & 0.004 & 0.003 & 0.043 & 0.043 & -0.788 & 1.598 & -15.714 & -16.785 & -15.446 \\
\hline & $(0.56)$ & $(1.20)$ & $(-0.18)$ & $(-0.40)$ & $(0.00)$ & $(-1.36)$ & $(0.09)$ & $(0.06)$ & $(0.96)$ & $(0.70)$ & $(-0.24)$ & $(0.19)$ & $(-0.86)$ & $(-1.27)$ & $(-1.24)$ \\
\hline \multirow[t]{2}{*}{ GDP growth rate } & 0.028 & 0.064 & 0.010 & 0.054 & 0.098 & -0.004 & $0.106^{* * *}$ & 0.052 & 0.074 & $0.153^{* * *}$ & $4.882^{*}$ & $4.278^{* *}$ & 2.007 & $4.903^{* *}$ & -2.489 \\
\hline & $(0.60)$ & $(1.33)$ & (0.19) & $(0.62)$ & $(1.47)$ & $(-0.12)$ & (3.03) & $(1.25)$ & $(1.28)$ & (3.62) & $(1.88)$ & $(2.15)$ & $(0.65)$ & (2.29) & $(-0.27)$ \\
\hline \multirow[t]{2}{*}{ Consumption growth rate } & -0.009 & -0.016 & $0.201 *$ & 0.176 & 0.216 & -0.052 & 0.018 & 0.043 & 0.045 & 0.087 & 0.414 & 0.133 & $16.854^{* * *}$ & $15.594 * * *$ & -2.037 \\
\hline & $(-0.10)$ & $(-0.30)$ & $(1.94)$ & $(1.57)$ & $(1.26)$ & $(-1.37)$ & $(0.34)$ & $(0.72)$ & $(0.53)$ & $(1.40)$ & $(0.09)$ & $(0.07)$ & $(5.46)$ & (8.88) & $(-0.14)$ \\
\hline \multirow[t]{2}{*}{$\begin{array}{l}\text { Private investment growth } \\
\text { rate }\end{array}$} & $0.438^{* *}$ & 0.315 & 0.153 & 0.317 & 0.292 & 0.064 & 0.269 & 0.261 & 0.090 & $0.453^{* * *}$ & $26.370^{* *}$ & 20.802 & 20.513 & 46.540 & 13.793 \\
\hline & $(2.61)$ & $(1.56)$ & $(0.52)$ & $(0.77)$ & $(0.69)$ & $(0.24)$ & $(1.60)$ & (1.50) & $(0.65)$ & (2.92) & (2.19) & (1.68) & $(1.02)$ & $(1.28)$ & $(0.37)$ \\
\hline
\end{tabular}

${ }^{* \star *},{ }^{\star *}$, and * indicate statistical significance respectively at the $1 \%, 5 \%$, and $10 \%$ levels. Robust $t$-stat in parentheses. 
Table A5. Short-term impact of structural reforms (baseline specification) (cont.)

\begin{tabular}{|c|c|c|c|c|c|c|c|c|c|c|c|c|c|c|c|}
\hline \multirow{2}{*}{$\begin{array}{l}\text { Reform shocks } \\
\text { Years after the Reform }\end{array}$} & \multicolumn{5}{|c|}{ Decline in Job Protection on Regular Contracts } & \multicolumn{5}{|c|}{ Decline in Job Protection on Temporary Contracts } & \multicolumn{5}{|c|}{ Decline in Labour Tax Wedge } \\
\hline & Y1 & Y2 & Y3 & Y4 & Y5 & $\mathrm{Y1}$ & $\mathrm{Y} 2$ & Y3 & Y4 & Y5 & Y1 & Y2 & Y3 & Y4 & Y5 \\
\hline \multicolumn{16}{|l|}{ Dependent variables } \\
\hline \multirow[t]{2}{*}{ Aggregate employment } & 0.711 & 1.108 & 1.460 & 1.925 & 2.167 & $-0.147^{*}$ & -0.047 & -0.215 & $-0.665^{*}$ & $-1.222 * * *$ & 0.035 & 0.116 & 0.011 & -0.061 & -0.121 \\
\hline & $(0.89)$ & $(0.81)$ & $(0.82)$ & $(0.94)$ & $(1.49)$ & $(-1.78)$ & $(-0.37)$ & $(-0.80)$ & $(-2.01)$ & $(-2.96)$ & $(0.54)$ & $(0.83)$ & $(0.07)$ & $(-0.42)$ & $(-0.71)$ \\
\hline \multirow[t]{2}{*}{ Youth } & 1.092 & 1.036 & 1.400 & 1.329 & 2.298 & 0.121 & 0.171 & -0.411 & $-1.175^{* *}$ & -1.337 & 0.085 & 0.210 & 0.168 & -0.025 & -0.200 \\
\hline & $(0.83)$ & (0.44) & $(0.52)$ & $(0.45)$ & (1.02) & $(0.49)$ & $(0.52)$ & $(-0.91)$ & $(-2.24)$ & $(-1.55)$ & $(0.69)$ & $(0.80)$ & $(0.58)$ & $(-0.09)$ & $(-0.63)$ \\
\hline \multirow[t]{2}{*}{ Women } & 0.380 & 1.068 & 1.607 & 1.949 & 1.573 & -0.134 & 0.064 & -0.017 & -0.609 & -1.024 & 0.070 & 0.119 & 0.034 & 0.042 & 0.103 \\
\hline & $(0.56)$ & $(0.94)$ & $(0.87)$ & $(0.83)$ & $(1.03)$ & $(-0.85)$ & $(0.26)$ & $(-0.05)$ & $(-1.44)$ & $(-1.61)$ & $(1.12)$ & $(0.96)$ & $(0.22)$ & $(0.24)$ & $(0.47)$ \\
\hline \multirow[t]{2}{*}{ Senior } & -0.145 & 0.798 & 1.515 & 2.623 & 1.371 & -0.357 & 0.130 & 0.117 & -0.001 & 0.096 & 0.021 & $0.229 * * *$ & 0.115 & 0.066 & -0.044 \\
\hline & $(-0.33)$ & $(1.18)$ & $(1.26)$ & $(1.69)$ & $(1.40)$ & $(-1.10)$ & $(0.39)$ & $(0.27)$ & $(0.00)$ & $(0.16)$ & $(0.24)$ & $(3.13)$ & $(1.24)$ & $(0.47)$ & $(-0.23)$ \\
\hline \multirow[t]{2}{*}{ Aggregate unemployment } & $-1.583^{* *}$ & -1.902 & -1.962 & -2.372 & $-2.728^{* *}$ & 0.231 & 0.070 & 0.009 & 0.262 & 0.635 & -0.025 & -0.032 & 0.081 & 0.068 & 0.133 \\
\hline & $(-2.22)$ & $(-1.70)$ & $(-1.39)$ & $(-1.41)$ & $(-2.37)$ & $(1.44)$ & $(0.27)$ & $(0.03)$ & $(0.62)$ & $(1.53)$ & $(-0.51)$ & $(-0.30)$ & $(0.55)$ & $(0.44)$ & $(0.85)$ \\
\hline \multirow{2}{*}{ Youth } & $-3.034^{* *}$ & -2.720 & -2.835 & -2.691 & $-3.350^{* *}$ & -0.072 & -0.260 & -0.487 & 0.206 & 0.574 & -0.057 & -0.013 & 0.217 & 0.188 & 0.293 \\
\hline & $(-2.31)$ & $(-1.42)$ & $(-1.36)$ & $(-0.91)$ & $(-2.35)$ & $(-0.32)$ & $(-0.45)$ & $(-1.14)$ & $(0.30)$ & $(1.07)$ & $(-0.46)$ & $(-0.05)$ & $(0.66)$ & $(0.59)$ & $(0.91)$ \\
\hline \multirow[t]{2}{*}{ Women } & $-1.637^{* *}$ & $-2.647^{* * *}$ & $-2.835^{* * *}$ & $-3.415^{* * *}$ & $-4.255^{* * *}$ & $0.318^{*}$ & 0.027 & 0.002 & 0.008 & 0.618 & -0.029 & -0.038 & 0.052 & -0.029 & 0.070 \\
\hline & $(-2.63)$ & $(-3.86)$ & $(-2.82)$ & $(-2.92)$ & $(-5.43)$ & $(1.89)$ & $(0.13)$ & $(0.01)$ & $(0.02)$ & $(1.20)$ & $(-0.65)$ & $(-0.40)$ & $(0.37)$ & $(-0.19)$ & $(0.44)$ \\
\hline \multirow[t]{2}{*}{ Senior } & -0.494 & -1.872 & -2.253 & -2.521 & -1.832 & -0.015 & -0.100 & -0.211 & -0.138 & -0.155 & 0.081 & 0.020 & 0.064 & 0.037 & 0.170 \\
\hline & $(-0.76)$ & $(-1.42)$ & $(-1.20)$ & $(-1.39)$ & $(-1.41)$ & $(-0.05)$ & $(-0.24)$ & $(-0.55)$ & $(-0.26)$ & $(-0.25)$ & $(1.00)$ & $(0.22)$ & $(0.54)$ & $(0.22)$ & $(0.90)$ \\
\hline \multirow[t]{2}{*}{ Aggregate participation } & -0.220 & -0.070 & 0.192 & 0.305 & 0.032 & -0.007 & -0.031 & -0.228 & $-0.424 * * *$ & $-0.703 * *$ & -0.001 & 0.060 & 0.044 & 0.006 & 0.005 \\
\hline & $(-0.67)$ & $(-0.13)$ & $(0.27)$ & $(0.31)$ & $(0.04)$ & $(-0.07)$ & $(-0.19)$ & $(-1.02)$ & $(-2.82)$ & $(-2.67)$ & $(-0.03)$ & $(0.86)$ & $(0.58)$ & $(0.07)$ & $(0.04)$ \\
\hline \multirow[t]{2}{*}{ Youth } & -0.100 & 0.090 & 0.334 & -0.347 & -0.268 & 0.244 & -0.007 & -0.658 & $-1.023^{*}$ & -1.043 & 0.001 & 0.201 & 0.263 & 0.133 & 0.023 \\
\hline & $(-0.09)$ & $(0.04)$ & $(0.13)$ & $(-0.13)$ & $(-0.11)$ & $(1.01)$ & $(-0.03)$ & $(-1.22)$ & $(-1.90)$ & $(-1.39)$ & $(0.01)$ & $(1.00)$ & $(1.33)$ & $(0.62)$ & $(0.08)$ \\
\hline \multirow[t]{2}{*}{ Women } & 0.019 & 0.271 & 0.951 & 1.018 & -0.034 & 0.050 & -0.036 & -0.093 & $-0.602^{* *}$ & -0.684 & 0.064 & 0.078 & 0.053 & 0.069 & 0.251 \\
\hline & $(0.07)$ & $(0.61)$ & $(1.15)$ & $(0.82)$ & $(-0.04)$ & $(0.27)$ & $(-0.13)$ & $(-0.43)$ & $(-2.38)$ & $(-1.48)$ & $(1.09)$ & $(0.77)$ & $(0.36)$ & $(0.43)$ & $(1.43)$ \\
\hline \multirow[t]{2}{*}{ Senior } & -0.473 & -0.380 & 0.079 & 1.005 & 0.025 & -0.420 & 0.062 & 0.007 & 0.014 & 0.036 & 0.042 & $0.210^{* *}$ & 0.135 & 0.060 & -0.101 \\
\hline & $(-1.53)$ & $(-0.93)$ & $(0.12)$ & $(1.29)$ & $(0.03)$ & $(-1.12)$ & $(0.15)$ & $(0.01)$ & $(0.02)$ & $(0.05)$ & $(0.49)$ & $(2.32)$ & $(1.57)$ & $(0.47)$ & $(-0.55)$ \\
\hline \multirow[t]{2}{*}{ GDP growth rate } & 2.926 & 0.834 & 1.142 & 2.145 & 0.589 & $-0.679 * *$ & $-0.747^{*}$ & -0.426 & $-0.799 * *$ & -0.107 & 0.031 & 0.056 & -0.011 & -0.007 & 0.033 \\
\hline & $(1.13)$ & $(0.49)$ & $(0.75)$ & $(1.57)$ & $(1.50)$ & $(-2.06)$ & $(-1.78)$ & $(-1.29)$ & $(-2.77)$ & $(-0.37)$ & $(0.25)$ & $(0.51)$ & $(-0.12)$ & $(-0.03)$ & $(0.19)$ \\
\hline \multirow[t]{2}{*}{ Consumption growth rate } & 5.628 & 1.634 & 1.498 & 3.003 & -0.678 & -0.512 & -0.675 & -0.110 & $-0.822 * *$ & $-1.108^{* *}$ & -0.201 & -0.130 & -0.325 & -0.102 & -0.225 \\
\hline & $(1.20)$ & $(0.69)$ & $(1.20)$ & $(1.63)$ & $(-0.55)$ & $(-1.52)$ & $(-1.35)$ & $(-0.26)$ & $(-2.14)$ & $(-2.35)$ & $(-1.44)$ & $(-0.60)$ & $(-1.58)$ & $(-0.45)$ & $(-1.14)$ \\
\hline \multirow[t]{2}{*}{ Private investment growth rate } & 3.620 & -0.891 & -1.909 & $7.228^{* *}$ & $6.282^{* *}$ & $-3.444 * *$ & -2.312 & -0.204 & -0.915 & -1.983 & 0.496 & 0.015 & -0.437 & -0.191 & 0.665 \\
\hline & $(1.36)$ & $(-0.39)$ & $(-1.28)$ & $(2.40)$ & $(2.58)$ & $(-2.37)$ & $(-0.92)$ & $(-0.16)$ & $(-0.59)$ & $(-1.15)$ & $(0.91)$ & $(0.02)$ & $(-1.67)$ & $(-0.33)$ & $(1.18)$ \\
\hline
\end{tabular}

${ }^{* * *},{ }^{* *}$, and * indicate statistical significance respectively at the $1 \%, 5 \%$, and $10 \%$ statistical levels. Robust $t$-stat in parentheses. 
Table A5. Short-term impact of structural reforms (baseline specification) (cont.)

\begin{tabular}{|c|c|c|c|c|c|c|c|c|c|c|c|c|c|c|c|}
\hline \multirow{2}{*}{$\begin{array}{l}\text { Reform shocks } \\
\text { Years after the Reform }\end{array}$} & \multicolumn{5}{|c|}{$\begin{array}{c}\text { Decline in the Share of Income Tax in Total Tax } \\
\text { Revenues }\end{array}$} & \multicolumn{5}{|c|}{ Increase in Spending on ALMP in Training } & \multicolumn{5}{|c|}{ Increase in Spending on ALMP in Employment Incentives } \\
\hline & Y1 & $\mathrm{Y} 2$ & Y3 & Y4 & Y5 & Y1 & Y2 & Y3 & Y4 & Y5 & Y1 & Y2 & Y3 & Y4 & Y5 \\
\hline \multicolumn{16}{|l|}{ Dependent variables } \\
\hline \multirow[t]{2}{*}{ Aggregate employment } & 0.057 & 0.095 & 0.070 & 0.006 & -0.006 & 0.033 & 0.056 & 0.081 & 0.094 & 0.039 & $0.153^{* *}$ & $0.303^{* * *}$ & $0.374^{* * *}$ & $0.316^{* * *}$ & 0.099 \\
\hline & $(1.07)$ & $(1.14)$ & $(0.56)$ & $(0.04)$ & $(-0.04)$ & $(1.70)$ & $(1.02)$ & $\begin{array}{l}(0.97) \\
\end{array}$ & $(0.90)$ & $(0.37)$ & $(2.64)$ & (3.27) & (3.33) & $(3.22)$ & $(0.98)$ \\
\hline \multirow[t]{2}{*}{ Youth } & 0.086 & 0.208 & 0.132 & -0.035 & -0.155 & -0.005 & 0.053 & 0.041 & 0.038 & -0.094 & 0.315 & $0.517 *$ & 0.487 & 0.301 & -0.134 \\
\hline & $(0.86)$ & $(1.66)$ & $(0.74)$ & $(-0.18)$ & $(-0.67)$ & $(-0.09)$ & $(0.37)$ & $(0.21)$ & $(0.19)$ & $(-0.51)$ & $(1.10)$ & $(1.86)$ & (1.43) & $(0.94)$ & $(-0.43)$ \\
\hline \multirow[t]{2}{*}{ Women } & 0.065 & 0.115 & 0.163 & 0.095 & 0.143 & $0.065^{*}$ & 0.081 & $0.152^{*}$ & 0.175 & 0.159 & 0.087 & $0.241 * *$ & $0.254^{* *}$ & $0.233^{* *}$ & 0.043 \\
\hline & $(1.18)$ & $(1.38)$ & $(1.34)$ & $(0.59)$ & $(0.74)$ & $(1.85)$ & $(1.57)$ & $(1.87)$ & $(1.71)$ & $(1.27)$ & $(1.06)$ & $(2.08)$ & $(2.09)$ & $(2.33)$ & $(0.32)$ \\
\hline \multirow[t]{2}{*}{ Senior } & -0.034 & 0.002 & -0.048 & -0.010 & -0.059 & 0.045 & 0.089 & 0.105 & $0.216^{* *}$ & $0.175^{*}$ & -0.026 & 0.137 & $0.376^{* *}$ & $0.283^{*}$ & 0.163 \\
\hline & $(-0.57)$ & $(0.01)$ & $(-0.32)$ & $(-0.06)$ & $(-0.32)$ & $(0.96)$ & $(1.11)$ & $(1.05)$ & $(2.34)$ & $(1.85)$ & $(-0.36)$ & $(0.98)$ & (2.51) & $(1.87)$ & $(1.11)$ \\
\hline \multirow[t]{2}{*}{ Aggregate unemployment } & $-0.073 *$ & -0.063 & -0.004 & 0.041 & 0.005 & -0.002 & $-0.075 *$ & -0.072 & -0.051 & $\begin{array}{l}-0.033 \\
\end{array}$ & -0.035 & $-0.105^{*}$ & -0.191* & -0.173 & -0.126 \\
\hline & $(-1.80)$ & $(-0.77)$ & $(-0.03)$ & $(0.32)$ & $(0.03)$ & $(-0.06)$ & $(-1.71)$ & $(-1.21)$ & $(-0.57)$ & $(-0.33)$ & $(-0.73)$ & $(-1.99)$ & $(-1.83)$ & $(-1.53)$ & $(-0.91)$ \\
\hline \multirow[t]{2}{*}{ Youth } & $-0.168 *$ & -0.190 & -0.145 & -0.016 & -0.051 & 0.010 & $-0.162 *$ & -0.136 & -0.098 & -0.052 & -0.007 & -0.127 & -0.326 & -0.308 & -0.059 \\
\hline & $(-1.91)$ & $(-1.54)$ & $(-0.75)$ & $(-0.07)$ & $(-0.20)$ & $(0.16)$ & $(-2.00)$ & $(-1.19)$ & $(-0.65)$ & $(-0.35)$ & $(-0.06)$ & $(-0.77)$ & $(-1.14)$ & $(-1.20)$ & $(-0.17)$ \\
\hline \multirow[t]{2}{*}{ Women } & -0.054 & -0.046 & -0.003 & 0.021 & -0.035 & 0.003 & $-0.067 *$ & -0.066 & -0.062 & -0.065 & -0.043 & $-0.163 * *$ & $-0.215^{*}$ & -0.211 & $-0.229 *$ \\
\hline & $(-1.05)$ & $(-0.48)$ & $(-0.02)$ & $(0.13)$ & $(-0.20)$ & $(0.09)$ & $(-1.82)$ & $(-0.99)$ & $(-0.61)$ & $(-0.58)$ & $(-1.53)$ & $(-2.75)$ & $(-1.82)$ & $(-1.62)$ & $(-1.71)$ \\
\hline \multirow[t]{2}{*}{ Senior } & 0.031 & -0.076 & 0.036 & 0.055 & 0.112 & -0.015 & -0.034 & -0.033 & -0.040 & -0.046 & 0.047 & 0.017 & -0.048 & -0.159 & -0.162 \\
\hline & $(0.68)$ & $(-0.87)$ & $(0.36)$ & $(0.56)$ & $(0.99)$ & $(-0.25)$ & $(-0.50)$ & $(-0.49)$ & $(-0.49)$ & $(-0.57)$ & $(0.82)$ & $(0.21)$ & $(-0.41)$ & $(-1.31)$ & $(-1.13)$ \\
\hline \multirow[t]{2}{*}{ Aggregate participation } & 0.000 & 0.041 & 0.047 & -0.020 & -0.050 & 0.016 & -0.024 & 0.005 & 0.028 & -0.016 & 0.086 & $0.170^{* *}$ & $0.183^{* *}$ & $0.163^{* *}$ & 0.024 \\
\hline & $(0.00)$ & $(1.05)$ & $(0.85)$ & $(-0.29)$ & $(-0.57)$ & $(0.80)$ & $(-0.48)$ & $(0.09)$ & $(0.45)$ & $(-0.25)$ & $(1.36)$ & (2.12) & (2.16) & (2.15) & $(0.38)$ \\
\hline \multirow[t]{2}{*}{ Youth } & 0.053 & $0.207^{*}$ & 0.144 & -0.016 & -0.177 & -0.012 & -0.069 & -0.037 & -0.007 & -0.129 & 0.247 & 0.399 & 0.311 & 0.208 & -0.067 \\
\hline & $(0.68)$ & $(1.74)$ & $(1.00)$ & $(-0.10)$ & $(-0.99)$ & $(-0.15)$ & $(-0.45)$ & $(-0.18)$ & $(-0.04)$ & $(-0.65)$ & $(0.93)$ & $(1.63)$ & $(1.04)$ & $(0.62)$ & $(-0.23)$ \\
\hline \multirow[t]{2}{*}{ Women } & 0.037 & $0.096^{*}$ & $0.134^{* *}$ & 0.032 & 0.072 & 0.026 & -0.003 & 0.068 & 0.087 & 0.071 & 0.008 & 0.063 & 0.034 & 0.044 & -0.110 \\
\hline & $(0.81)$ & (1.72) & $(2.17)$ & $(0.39)$ & $(0.68)$ & $(0.95)$ & $(-0.07)$ & $(0.97)$ & $(1.22)$ & $(0.87)$ & $(0.11)$ & $(0.60)$ & $(0.30)$ & $(0.54)$ & $(-0.74)$ \\
\hline \multirow[t]{2}{*}{ Senior } & -0.022 & -0.026 & -0.020 & 0.005 & -0.007 & 0.049 & 0.071 & 0.085 & $0.182^{* *}$ & $0.146^{*}$ & -0.031 & 0.132 & $0.326 * *$ & 0.217 & 0.128 \\
\hline & $(-0.37)$ & $(-0.28)$ & $(-0.16)$ & $(0.03)$ & $(-0.04)$ & $(1.48)$ & $(1.15)$ & $(0.95)$ & $(2.48)$ & $(1.87)$ & $(-0.35)$ & $(0.95)$ & (2.19) & $(1.27)$ & $(0.91)$ \\
\hline \multirow[t]{2}{*}{ GDP growth rate } & 0.052 & 0.045 & 0.113 & -0.021 & 0.026 & -0.016 & -0.074 & -0.084 & -0.052 & -0.040 & 0.037 & -0.014 & 0.065 & -0.171 & -0.124 \\
\hline & $(0.59)$ & $(0.39)$ & $(0.98)$ & $(-0.20)$ & $(0.21)$ & $(-0.29)$ & $(-0.71)$ & $(-0.89)$ & $(-0.57)$ & $(-0.54)$ & $(0.35)$ & $(-0.14)$ & $(0.62)$ & $(-1.43)$ & $(-0.80)$ \\
\hline \multirow[t]{2}{*}{ Consumption growth rate } & 0.052 & 0.094 & -0.058 & 0.009 & -0.013 & -0.004 & -0.094 & $-0.183^{* *}$ & -0.116 & $-0.167^{* *}$ & 0.131 & -0.129 & 0.011 & -0.050 & 0.030 \\
\hline & $(0.87)$ & $(0.82)$ & $(-0.51)$ & $(0.08)$ & $(-0.11)$ & $(-0.07)$ & $(-1.00)$ & $(-2.29)$ & $(-1.19)$ & $(-2.56)$ & $(0.91)$ & $(-1.29)$ & $(0.08)$ & $(-0.59)$ & $(0.28)$ \\
\hline \multirow[t]{2}{*}{ Private investment growth rate } & 0.484 & $0.536^{* *}$ & 0.428 & 0.241 & 0.277 & -0.069 & 0.312 & 0.084 & 0.588 & -0.090 & -0.007 & 0.068 & -0.325 & -0.766 & -0.420 \\
\hline & $(1.03)$ & $(2.31)$ & $(1.12)$ & $(1.01)$ & $(0.53)$ & $(-0.36)$ & $(1.36)$ & $(0.38)$ & $(1.55)$ & $(-0.43)$ & $(-0.02)$ & $(0.14)$ & $(-0.51)$ & $(-0.95)$ & $(-1.06)$ \\
\hline
\end{tabular}

$* \star *, * *$, and * indicate statistical significance respectively at the $1 \%, 5 \%$, and $10 \%$ statistical levels. Robust $t$-stat in parentheses. 
Table A5. Short-term impact of structural reforms (baseline specification) (cont.)

\begin{tabular}{|c|c|c|c|c|c|c|c|c|c|c|}
\hline \multirow{2}{*}{$\begin{array}{l}\text { Reform shocks } \\
\text { Years after the Reform }\end{array}$} & \multicolumn{5}{|c|}{ Reduction of "excess" coverage of collective bargaining } & \multicolumn{5}{|c|}{ Decline in Product Market Regulation } \\
\hline & Y1 & Y2 & Y3 & Y4 & Y5 & Y1 & Y2 & Y3 & Y4 & Y5 \\
\hline \multicolumn{11}{|l|}{ Dependent variables } \\
\hline \multirow[t]{2}{*}{ Aggregate employment } & 0.007 & 0.016 & 0.021 & 0.034 & 0.036 & 0.187 & 0.309 & 0.664 & 0.988 & 0.958 \\
\hline & $(0.47)$ & $(0.62)$ & $(0.84)$ & $(1.37)$ & $(1.34)$ & $(0.83)$ & $(0.86)$ & $(0.96)$ & $(1.30)$ & $(1.36)$ \\
\hline \multirow[t]{2}{*}{ Youth } & 0.016 & 0.024 & 0.030 & 0.041 & 0.022 & 0.048 & 0.243 & 1.024 & 1.470 & 1.261 \\
\hline & $(0.73)$ & $(0.58)$ & $(0.68)$ & $(0.97)$ & $(0.62)$ & $(0.11)$ & $(0.37)$ & $(0.89)$ & $(1.03)$ & $(0.96)$ \\
\hline \multirow[t]{2}{*}{ Women } & 0.005 & 0.024 & 0.028 & 0.031 & 0.027 & 0.425 & 0.623 & 1.056 & $1.413^{* *}$ & $1.397^{*}$ \\
\hline & $(0.24)$ & $(1.27)$ & (1.42) & (1.41) & $(0.71)$ & $(1.35)$ & $(1.48)$ & (1.61) & $(2.06)$ & (1.96) \\
\hline \multirow[t]{2}{*}{ Senior } & $0.047^{* *}$ & 0.035 & 0.014 & $0.044^{* *}$ & $0.060^{* *}$ & -0.053 & 0.093 & 0.113 & 0.408 & 0.167 \\
\hline & $(2.60)$ & $(1.15)$ & $(0.70)$ & $(2.16)$ & $(2.21)$ & $(-0.16)$ & $(0.19)$ & $(0.15)$ & $(0.53)$ & $(0.19)$ \\
\hline \multirow[t]{2}{*}{ Aggregate unemployment } & 0.004 & -0.008 & -0.019 & -0.026 & -0.031 & 0.093 & -0.152 & 0.126 & -0.201 & -0.468 \\
\hline & $(0.34)$ & $(-0.43)$ & $(-1.11)$ & $(-1.44)$ & $(-1.54)$ & $(0.47)$ & $(-0.42)$ & $(0.18)$ & $(-0.27)$ & $(-0.71)$ \\
\hline \multirow[t]{2}{*}{ Youth } & -0.008 & -0.037 & -0.060 & $-0.069 * *$ & -0.043 & 0.195 & -0.565 & 0.360 & 0.029 & -0.733 \\
\hline & $(-0.32)$ & $(-1.10)$ & $(-1.62)$ & $(-2.14)$ & $(-1.00)$ & $(0.36)$ & $(-0.73)$ & $(0.30)$ & $(0.02)$ & $(-0.63)$ \\
\hline \multirow[t]{2}{*}{ Women } & 0.001 & $-0.017^{*}$ & $-0.039 * *$ & $-0.051^{* *}$ & $-0.059^{* *}$ & -0.079 & -0.423 & -0.185 & -0.743 & $-1.154^{*}$ \\
\hline & $\begin{array}{l}(0.14) \\
\end{array}$ & $(-1.88)$ & $(-2.17)$ & $(-2.17)$ & $(-2.54)$ & $(-0.35)$ & $(-0.96)$ & $(-0.24)$ & $(-0.92)$ & $(-1.71)$ \\
\hline \multirow[t]{2}{*}{ Senior } & -0.015 & $-0.026 *$ & 0.005 & -0.016 & $-0.046^{* *}$ & -0.260 & -0.385 & 0.055 & -0.595 & -0.950 \\
\hline & $(-1.42)$ & $(-1.76)$ & $(0.21)$ & $(-0.79)$ & $(-2.44)$ & $(-1.57)$ & $(-1.22)$ & $(0.09)$ & $(-0.70)$ & $(-1.05)$ \\
\hline \multirow[t]{2}{*}{ Aggregate participation } & 0.012 & 0.013 & 0.006 & $0.017^{*}$ & 0.021 & 0.232 & 0.121 & $0.701^{* *}$ & $0.895^{* *}$ & $0.806^{* *}$ \\
\hline & $(1.65)$ & (1.19) & $(0.57)$ & $(1.93)$ & $(1.60)$ & $(1.62)$ & $(0.56)$ & $(2.19)$ & $(2.37)$ & $(2.26)$ \\
\hline \multirow[t]{2}{*}{ Youth } & $0.026^{*}$ & 0.019 & 0.015 & 0.016 & 0.019 & 0.108 & -0.173 & 1.025 & 1.438 & 1.131 \\
\hline & $(1.88)$ & $(0.73)$ & $(0.50)$ & $(0.54)$ & $(0.97)$ & $(0.23)$ & $(-0.27)$ & $(1.16)$ & $(1.11)$ & $(0.83)$ \\
\hline \multirow[t]{2}{*}{ Women } & 0.008 & 0.012 & -0.001 & -0.006 & -0.015 & 0.354 & 0.191 & $0.888^{*}$ & $1.020^{* *}$ & 0.881 \\
\hline & $(0.36)$ & $(0.76)$ & $(-0.08)$ & $(-0.36)$ & $(-0.47)$ & $(1.45)$ & $(0.59)$ & $(2.02)$ & $(2.16)$ & $(1.62)$ \\
\hline \multirow[t]{2}{*}{ Senior } & $0.041 * * *$ & 0.021 & 0.013 & 0.036 & 0.033* & -0.311 & -0.247 & -0.128 & -0.044 & -0.443 \\
\hline & (3.13) & $(0.96)$ & $(0.64)$ & $(1.63)$ & $(1.72)$ & $(-0.91)$ & $(-0.46)$ & $(-0.17)$ & $(-0.05)$ & $(-0.51)$ \\
\hline \multirow[t]{2}{*}{ GDP growth rate } & 0.039 & 0.058 & $0.076^{* * *}$ & 0.009 & -0.009 & 0.291 & 0.188 & -0.124 & $-0.764^{*}$ & -0.454 \\
\hline & $(1.13)$ & $(1.67)$ & $(3.81)$ & $(0.40)$ & $(-0.46)$ & $(1.00)$ & $(0.51)$ & $(-0.23)$ & $(-1.86)$ & $(-0.77)$ \\
\hline \multirow[t]{2}{*}{ Consumption growth rate } & 0.017 & 0.043 & $0.099 * * *$ & -0.014 & -0.020 & $1.214^{* *}$ & 0.028 & -0.380 & -0.555 & -0.003 \\
\hline & $(0.37)$ & $(0.95)$ & $(5.13)$ & $(-0.76)$ & $(-1.14)$ & (2.28) & $(0.05)$ & $(-0.50)$ & $(-1.09)$ & $(0.00)$ \\
\hline \multirow[t]{2}{*}{ Private investment growth rate } & -0.114 & -0.022 & -0.013 & -0.010 & -0.001 & 2.083 & 0.156 & -0.823 & $-4.236^{*}$ & -2.391 \\
\hline & $(-1.37)$ & $(-0.22)$ & $(-0.15)$ & $(-0.16)$ & $(-0.01)$ & $(1.44)$ & $(0.12)$ & $(-0.32)$ & $(-1.89)$ & $(-1.25)$ \\
\hline
\end{tabular}

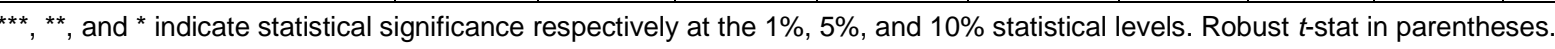


Table A5. Short-term impact of structural reforms (baseline specification) (cont.)

\begin{tabular}{|c|c|c|c|c|c|c|c|c|c|c|}
\hline \multirow{2}{*}{\begin{tabular}{|l|} 
Reform shocks \\
Years after the Reform \\
\end{tabular}} & \multicolumn{5}{|c|}{ Increase in Minimum Retirement Age } & \multicolumn{5}{|c|}{ Decline in Implicit Tax on Continued Work } \\
\hline & $\mathrm{Y} 1$ & Y2 & Y3 & Y4 & Y5 & Y1 & Y2 & Y3 & Y4 & Y5 \\
\hline \multicolumn{11}{|l|}{ Dependent variables } \\
\hline \multirow[t]{2}{*}{ Senior employment } & $-0.743 * * *$ & $-1.203^{* * *}$ & $-1.916 * * *$ & $-2.226 * * *$ & $-2.240 * * *$ & -0.034 & $-0.076 * * *$ & $-0.131 * * *$ & $-0.151^{* *}$ & $-0.164 * *$ \\
\hline & $(-5.39)$ & $(-4.68)$ & $(-6.71)$ & $(-6.05)$ & $(-4.57)$ & $(-1.52)$ & $(-6.26)$ & $(-4.09)$ & $(-2.57)$ & $(-2.54)$ \\
\hline \multirow[t]{2}{*}{ Senior unemployment } & 0.193 & $0.520 * *$ & $1.022^{* * *}$ & $1.152^{* * *}$ & $1.426 * * *$ & -0.009 & 0.004 & 0.030 & 0.019 & 0.035 \\
\hline & $(1.37)$ & $(2.78)$ & $(3.88)$ & $(5.16)$ & $(4.49)$ & $(-0.69)$ & $(0.16)$ & $(1.03)$ & $(0.51)$ & $(0.68)$ \\
\hline \multirow[t]{2}{*}{ Senior participation } & $-0.740 * * *$ & $-1.075^{* * *}$ & $-1.632^{* * *}$ & $-1.899 * * *$ & $-1.840 * * *$ & -0.038 & $-0.067 * * *$ & $-0.109 * * *$ & $-0.128 * * *$ & $-0.136 * *$ \\
\hline & $(-3.99)$ & $(-3.65)$ & $(-4.83)$ & $(-4.75)$ & $(-3.85)$ & $(-1.33)$ & $(-4.97)$ & $(-4.42)$ & $(-3.11)$ & $(-2.42)$ \\
\hline \multirow[t]{2}{*}{ GDP growth rate } & -0.141 & 0.132 & $1.368^{* *}$ & $0.799 * * *$ & $0.708^{* * *}$ & 0.005 & -0.006 & -0.032 & $0.064^{*}$ & $0.051^{* *}$ \\
\hline & $(-0.83)$ & $(0.53)$ & $(2.39)$ & $(5.50)$ & $(6.74)$ & $(0.15)$ & $(-0.16)$ & $(-0.89)$ & $(2.03)$ & $(2.75)$ \\
\hline \multirow[t]{2}{*}{ Consumption growth rate } & -0.249 & -0.060 & $0.654^{* *}$ & $0.812^{* * *}$ & $0.375^{* *}$ & 0.048 & 0.020 & -0.044 & 0.014 & 0.009 \\
\hline & $(-0.72)$ & $(-0.26)$ & $(2.70)$ & $(2.91)$ & $(2.41)$ & $(1.48)$ & $(0.39)$ & $(-0.93)$ & $(0.45)$ & $(0.39)$ \\
\hline \multirow[t]{2}{*}{$\begin{array}{l}\text { Private investment growth } \\
\text { rate }\end{array}$} & $-2.039 *$ & $-1.830 * *$ & -0.225 & $1.880^{*}$ & $2.751^{* *}$ & -0.016 & -0.074 & 0.151 & 0.265 & $0.179 *$ \\
\hline & $(-1.83)$ & $(-2.58)$ & $(-0.27)$ & $(1.81)$ & (2.59) & $(-0.12)$ & $(-0.74)$ & $(0.80)$ & (1.44) & (2.03) \\
\hline
\end{tabular}

***, **, and * indicate statistical significance respectively at the $1 \%, 5 \%$, and $10 \%$ statistical levels. Robust $t$-stat in parentheses. 


\section{WORKING PAPERS}

The full series of Economics Department Working Papers can be consulted at www.oecd.org/eco/workingpapers/

948. Short-term gain or pain? A DSGE model-based analysis of the short-term effects of structural reforms in labour and product markets

(March 2012) by Matteo Cacciatore, Romain Duval and Giuseppe Fiori

947. Do house prices impact consumption and interest rate?: Evidence from OECD countries using an agnostic identification procedure

(March 2012) by Christophe André, Rangan Gupta and Patrick T. Kanda

946. Assessing the sensitivity of Hungarian debt sustainability to macroeconomic shocks under two fiscal policy reactions

(March 2012) by Pierre Beynet and Edouard Paviot

945. Non-Keynesian effects of fiscal consolidation: an analysis with an estimated DSGE Model for the Hungarian economy

(March 2012) by Szilárd Benk and Zoltán M. Jakab

944. Work incentives and recent reforms of the tax and benefit system in Hungary

(March 2012) by Tímea Ladányi and Rafal Kierzenkowski

943. Building blocks for a better functioning housing market in Chile

(February 2012) by Aida Caldera Sánchez

942. The impact of changes in second pension pillars on public finances in Central and Eastern Europe (January 2012) by Balász Égert

941. Improving energy system efficiency in the Czech Republic (January 2012) by Artur Radziwill

940. Structural change and the current account: the case of Germany

(January 2012) by Fabrizio Coricelli and Andreas Wörgötter

939. Reforming education in England

(January 2012) by Henrik Braconier

938. The nature of financial and real business cycles: The great moderation and banking sector procyclicality

(January 2012) by Balázs Égert and Douglas Sutherland 
937. Fiscal consolidation

Part 6. What are the best policy instruments for fiscal consolidation?

(January 2012) by Robert P. Hagemann

936. Fiscal consolidation

Part 5. What factors determine the success of consolidation efforts?

(January 2012) by Margit Molnar

935. Fiscal consolidation

Part 4. Case studies of large fiscal consolidation episodes

(January 2012) by Hansjörg Blöchliger, Dae-Ho Song and Douglas Sutherland

934. Fiscal consolidation

Part 3. Long-run projections and fiscal gap calculations

(January 2012) by Rossana Merola and Douglas Sutherland

933. Fiscal consolidation

Part 2. Fiscal multipliers and fiscal consolidations

(forthcoming) by Ray Barrell, Dawn Holland and Ian Hurst

932. Fiscal consolidation

Part 1. How much is needed and how to reduce debt to a prudent level?

(January 2012) by Douglas Sutherland, Peter Hoeller and Rossana Merola

931. Less income inequality and more growth - Are they compatible?

Part 8. The drivers of labour income inequality - A review of the recent literature (forthcoming) by Rafal Kierzenkowski and Isabell Koske

930. Less income inequality and more growth - Are they compatible?

Part 7. The drivers of labour earnings inequality - An analysis based on conditional and unconditional quantile regressions

(January 2012) by Jean-Marc Fournier and Isabell Koske

929. Less income inequality and more growth - Are they compatible?

Part 6. The distribution of wealth

(January 2012) by Kaja Bonesmo Fredriksen

928. Less income inequality and more growth - Are they compatible?

Part 5. Poverty in OECD countries

(January 2012) by Mauro Pisu

927. Less income inequality and more growth - Are they compatible?

Part 4. Top incomes

(January 2012) by Peter Hoeller

926. Less income inequality and more growth - Are they compatible?

Part 3. Income redistribution via taxes and transfers across OECD countries

(January 2012) by Isabelle Joumard, Mauro Pisu and Debbie Bloch 